\title{
Flowcytometrisch onderzoek van normale en pathologisch veranderde humane epidermis, in het bijzonder van psoriasis
}

Citation for published version (APA):

Crombag, N. H. C. M. N. (1983). Flowcytometrisch onderzoek van normale en pathologisch veranderde humane epidermis, in het bijzonder van psoriasis. [Doctoral Thesis, Maastricht University].

Rijksuniversiteit Limburg. https://doi.org/10.26481/dis.19830630nc

Document status and date:

Published: 01/01/1983

DOI:

10.26481/dis.19830630nc

Document Version:

Publisher's PDF, also known as Version of record

Please check the document version of this publication:

- A submitted manuscript is the version of the article upon submission and before peer-review. There can be important differences between the submitted version and the official published version of record.

People interested in the research are advised to contact the author for the final version of the publication, or visit the DOI to the publisher's website.

- The final author version and the galley proof are versions of the publication after peer review.

- The final published version features the final layout of the paper including the volume, issue and page numbers.

Link to publication

\footnotetext{
General rights rights.

- You may freely distribute the URL identifying the publication in the public portal. please follow below link for the End User Agreement:

www.umlib.nl/taverne-license

Take down policy

If you believe that this document breaches copyright please contact us at:

repository@maastrichtuniversity.nl

providing details and we will investigate your claim.
}

Copyright and moral rights for the publications made accessible in the public portal are retained by the authors and/or other copyright owners and it is a condition of accessing publications that users recognise and abide by the legal requirements associated with these

- Users may download and print one copy of any publication from the public portal for the purpose of private study or research.

- You may not further distribute the material or use it for any profit-making activity or commercial gain

If the publication is distributed under the terms of Article $25 \mathrm{fa}$ of the Dutch Copyright Act, indicated by the "Taverne" license above, 


\section{FLOWCYTOMETRISCH ONDERZOEK VAN NORMALE EN PATHOLOGISCH VERANDERDE HUMANE EPIDERMIS, IN HET BIJZONDER VAN PSORIASIS}

\section{PROEFSCHRIFT}

ter werkrijging wan de graad van Doctor in de Geneeskunde aan de Rijksuniversiteit Limburg te Maastricht op gezag van de Rector Magnificus

Prof. Dr. H.C. Hemker, volgens het besluit van het College van Dekanen in het openbaar te verdedigen in de Aula van de Universiteit op

Donderdag 30 juni 1983

des namiddags te 16.00 uur

door

Nicolaas Hubert Christine Marie Noel Crombag geboren te Bunde 
Promotor: Prof. Dr. W.J.B.M. van de Staak

Copromotor: Dr. F.W. Bauer

Referenten: Prof. Dr. H.A.M. Hulsmans, Maastricht Prof. Dr. Dr. F.W.J. Gribnau, Nijmegen Dr. M.J. Woerdeman, Amsterdam 
Aan mijn ouders 
De onderzoekingen beschreven in dit proefschrift zijn uitgevoerd in de universiteitskliniek voor Huidziekten te Nijmegen (Hoofd: Prof. Dr. J.W.H. Mali). onderdelen van het onderzoek werden gepubliceerd in de internationale literatuur:

Crombag, N. \& Bauer, F.: De klinische mogelijkheden van de flowcytometrie. Ned. T'. Geneesk.,123, nr. $25: 1091,1979$.

Bauer, F.W., Crombag, N.H.C.M.N. \& De Grood, R.M.: Flowcytometry in Dermatology. Read before the workship: Epidermal cellular kinetics. XV International Congress of Dermatology, Mexico, 1977.

Bauer, F.W., Crombag, N.H.C.M.N., De Grood, R.M. \& De Jongh, G.J.: Flow cytometry as a tool for the study of cell kinetics in epidermis. Investigations on normal epidermis. Br. J. Derm.,102:629-639,1980.

Baluer, F.W., Crombag, N.H.C.M.N., De Grood, R.M. \& Boezeman, J.: Quantification of deviations of the epidermal DNA distributions in psoriasis and the effect of therapy. In: Flowcytometry 4:377-381,1980.

Bauer, F.W., Crombag, N.H.C.M.N., Boezeman, J. \& De Grood, R.M.: Flow cytometry as a tool for the study of cell kinetics in skin 2. Cell kinetic data in psoriasis. Br. J. Derm.,104:271-276,1981. 
INHOUD

Inleiding

Hoofdstuk 1: het ziektebeeld psoriasis

1.1. klinische manifestatie

1.2. aetiologie

1.3. histologie

1. 4. epiloog

1.5. referenties

Hoofdstuk 2: literatuuroverzlcht van diverse methoden ter bestudering van de celproliferatie var normale en psoriasis epidermis

2.1. inleiding

2.2. radiaactief gemerkte aminozuren

2.3. kleurstoffen

2.4. histogeometrie

2.5.1. mitotische index

2.5.2. mitotische index na stathmokinetische stoffen

2.6. autoradiografie

2.6.1. Inleiding en methoden

2.6.2. labelling index

2.6:3. volgen van gemerkte cellen op hun weg door de diverse compartimenten van de epidermis

2.6.4. Eraction labelled mitosis curve

2.6.5. dubbele labe11ing methode

2.6.6. continue labeliling methode

2.6 .7 . tellen van granulae

2.7. scintillatie teling

2.8. cytofotometrie

2.8.1. statische cytometrie

2.8.2. flowcytometrie

2.9. samenwatting en discussie

2.10 referenties 
Hoofdstuk 3: flowcytometrie: de methode van onderzoek

3.1. inleiding

3.2. flowcytometer

3.3. afname techniek

3.4. bewerking van het monster

3.5. analyse van de gegevens

3.5.1. histogram

3.5.2. mathematische analyse

3.5.3. coincidentie

3.6. moeilijkheden bij de interpretatie

3.6.1. klontjes

3.6.2. celbeschadiging, onvolledige kleuring en asymmetrie

3.6.3. correlatie met celcyclus- en turnovertija

3.7. referenties

Hoofdstuk 4: DNA distributie in normale humane epidermis

4.1. inleiding

4.2. materiaal en methode

4.3. resultaten

4.3.1. normaal waarden

4.3.2. invloed van het geslacht

4.3.3. invloed van de leeftijd

4.3.4. invloed van het seizoen

4.3.5. invloed van de plaats op het

lichaam

4. 4. discussie

4.5. referenties

Hoofdstuk 5: DNA distributie in laesies en klinisch niet aangetaste epidermis van psoriasispatienten

5.1. inleiding

5.2. materiaal en methode

5.3. resultaten

5.3.1. psoriasis vulgaris

5.3.2. inter-individuele en intra-individuele variantie 
5.3.3. intralaesionale variantie

5.3.4. onrustige psoriasis

5.3.5. psoriasis pustulosa

5.3.6. kilnisch niet aangetaste epidermis bij psoriasis

5.4. discussie

5.5. referenties

Hoofdstuk 6: DNA distributie in enkele andere dermatosen

6.1. inleiding

6.2. materiaal en methode

6.3. resultaten

6.3.1. neurodermitis

6.3.2. 1ichen ruber planus

6.3.3. morbus Darier

6.3.4. normale epidermis versus niet aangetaste epidermis bij personen met neurodermitis, resp. lichen ruber planus, resp. m. Darier

6.3.5. normale epidermis versus laesie van neurodermitis, lichen ruber planus en $m$. Darler

6.3.6. psoriasis vulgaris versus neurodermitis, lichen ruber planus en m. Darier

6.4. discussie

6.5. referenties

Hoofdstuk 7: Elowcytometrische bepaling van de therapleeffecten van een aantal veel toegepaste therapieregimes bij psoriasis vulgaris 7.1. inleiding

7.2. dithranol

7.2.1. inleiding

7.2.2. materiaal en methode

7.2.3. resultaten

7.2.4. discussie 
7.3. fotochemotherapie

7.3.1. inleiding

7.3.2. Goeckerman therapie

7.3.2.1. inleiding

7.3.2.2. materiaal en methode

7.3.2.3. resultaten

7.3.2.4. discussie

7.3.3. PUVA therapie

7.3.3.1. inleiding

7.3.3.2. materiaal en methode

$7 \cdot 3 \cdot 3 \cdot 3$. resultaten

7.3.3.4. discussie

7.4. Röntgen therapie

7.4.1. inleiding

7.4.2. materiaal en methode

7.4.3. resultaten

7.4.4. discussie

7.5. referenties

Samenvatting

Summary

Nawoord

Curriculum vitae. 
Psoriasis is een genetisch bepaalde huidaandoening, die zich manifiesteert als scherp begrensde, niet jeukende, rode, schilferende plekken. De oorzaak is onbekend. De beschikbare therapie is grotendeels empirisch en bestaat uit diverse combinaties van locale en orale chemotherapeutica.

Psoriasis wordt gekenmerkt door een versnelde celproliferatie. Celkinetische methoden bieden daarom de mogelijkheid psoriasis te onderzoeken. De ter beschikking staande technieken voor het verkrijgen van informatie over het proliferatiepatroon van normale en pathologisch veranderde epidermiscellen zijn arbeidsintensief en hebben vaak een beperkte statistische betrouwbarheid. Het tijdsinterval tussen afname van het monster en het ter beschikking staan van de resultaten is aanzienlijk (hoofdstuk 2).

Flowcytometrie (hoofdstuk 3), een in de afgelopen jaren ontwikkelde methode, die snelle en kwantitatleve informatie over het proliferatiepatroon van een celpopulatie mogelijk makt, wordt pas sinds kort in de dermatologie toegepast.

In dit proefschrift worden de bevindingen met de flowcytometer bij de proliferatie van normale en diverse vormen van pathologisch veranderde epidermis vermeld. In hoofdstuk 4 wordt aan de hand van de gevonden DNA verdelingen de turnover- en celcyclustijd van de normale humane epidermis bepaald. In hoofdstuk 5 worden de patronen van de epldermale celproliferatie bij diverse vormen van psoriasis, alsmede bij de klinisch niet aangetaste huid vermeld. Teneinde na te gaan of deze prollferatiepatronen specifiek voor psoriasis zijn, zijn in hoofdstuk 6 DNA verdelingen in de epidermale cellen bij een aantal andere dermatosen bepaald. De mogelijkheden van de flowcytometrie voor het onderzoek naar de celkinetische effecten van een antal veel toegepaste therapeutische regimes bij psoriasis worden in hoofdstuk 7 vermeld, waarbij het therapeutisch effect van dithranol, van een aantal fotochemotherapeutische regimes en van röntgenbestraling is nagegaan.

De hier vermelde resultaten moeten worden gezien als een eerste bijdrage tot het uiteindelijke doel van deze studie: het onderzoek naar een snelle bepaling van de voor ledere individuele psoriasis patient optimale geneesmiddel- en behandelingsschemata in de hoop aldus een bijdrage te leveren tot verbetering van de therapieresultaten bij de behandeling van psoriasis. 
HOOFDSTUK 1

HET ZIEKTEBEELD PSORIASIS.

1.1 Klinische manifestatie

1.2. Aetiologie

1.3 Histologie

1.4 Epliloog

1.5. Referenties 
De typische psoriasislaesies bestaan uit erythemateuze plekken die bedekt zijn met een dikke, mica-achtige, zilvergrijze, niet adherente schilfering. De laesies zijn licht verheven boven de omringende normale huid. Na grattage van een laesie ontstaat het $z . g$. kaarsvetfenomeen, bij verder krabben ontstaan puntvormige bloedinkjes (teken van Auspitz). De scherp begrensde plekken kunnen in grootte varieren van enkele tot honderden $\mathrm{cm}^{2}$. De a andoening jeukt als regel niet. Het verloop is voor de individuele patient onvoorspelbaar. Voor de meeste patienten is psoriasis een chronische, indolente aandoenling met onbegrepen perioden van exacerbatie en van partiële remissie.

Ofschoon psoriasis op elke plaats op het lichaam kan voorkomen bestaan er toch een aantal predilectieplaatsen: behaarde hoofd, gehoorgangen, ellebogen, knieën en de sacraalstreek. Wanneer de lichaamsplooien zijn aangetast spreekt men van psorilasis typus inversus.

De haargroei wordt in het algemeen nauwelijks aangetast, ondanks de vaak dikke schilferkorst op het behaarde hoofd (Comaish, 1969). Toch zouden haaruitval en kaalheid voorkomen zowel pleksgewijs als meer diffuus. Haarschacht anomalieën zijn bij psoriasis meermalen beschreven (Orfanos et al. 1970; Wyatt et al.,1972).

Nagelafwijkingen zijn frequent bij psoriasis. Bij aantasting van het proximale gedeelte van de nagelmatrix ontstan putjes en deukjes; wanneer de aandoening $z i c h$ in het nagelbed en hyponychium bevindt ontstaan onycholysis, subunguale keratose en ollevlekken (Alkiewilcs,1948; Lewin et a1.,1972). sinds de eerste publicatie van psoriasislaesies op de slijmvliezen door Oppenheim (1903) is het voorkomen van siljmvileslaesies controversieel gebleven (Ingram, 1954; E1Zawahry, 1973; Buchner et al.,1976).

Psoriasisarthropathie komt voor blj ongeveer $5 \%$ van de patienten met huidverschijnselen. Deze sero-negatieve arthropathie kan zich op meerdere manieren uiten (Mol1, 1979). Door meerdere auteurs is een significant hogere colncidentie beschreven van psoriasis en diabetes mellitus (BLnazz1 et al.,1975), myopathie (Mom et al.,1975), colitis ulcerosa (Burch \& Rowel1,1965), leverafwijkingen (Novotny,1981) en enkele andere afwijkingen (Ganor,1977).

Naast de meest voorkomende vorm, de bovenbeschreven psordasis vulgaris, bestaan er een aantal varianten van psoriasis, 
m.n. onrustige psoriasis, psoriasis pustulosa, acropustulosis en impetigo herpetiformis.

Bij de onrustige psoriasis manifesteren de zich ontwikkelende laesies $z i c h$ als een $z i c h$ snel uitbreidend erytheem met schilfering dat soms in zeer oppervlakkige pustels overgaat. Het begin is vaak meer acuut. De laesies geven soms een branderig gevoel. ook een chronisch verlopende psoriasis vulgaris kan overgaan in de onrustige vorm met ultbreiding van bestaande en een massale eruptie van nieuwe laesies. In de onrustige fase kunnen de laesies via het Koebner mechanisme (Koebner, 1877) of via aggravatie door irriterende stoffen $z i c h$ vergroten zodat een erythrodermie ontstaat.

Psoriasis pustulosa kan zich ontwikkelen als complicatie van een langerbestaande psoriasis, vaak na voorafgaande therapie met corticosteroiden, of volgend op een onrustige fase. Psoriasis pustulosa kan ook beginnen als een atypische presentatie van een late psoriasis. In dit geval zijn meestal de handen en voeten aangedaan. De aandoening begint als een acute zlekte met koorts en ernstige algemene malaise. Er ontstaan grote gebieden waar de huid pijnlijk en ontstoken is met vele pusteltjes die kunnen samenvloeien tot gee 1groene pusmeertjes. Bij een minder acuut begin kunnen gelocaliseerde of wijdverspreide anulaire erytheemplekken met pustels 1 de periferie ontstaan, die zich snel over grote gebieden van het lichaam kunnen uitbreiden. De pustels zijn sterie1.

Bij de acropustulosis bestaan in de handpalmen en op de voetzolen scherp begrensde pustuleuze erupties. De pustels zijn steriel, de eruptie is hardnekkig en resistent tegen therapie. De laesies komen frequent voor bij personen die de typische psoriasislaesies elders hebben, of deze later ontwikkelen, en kunnen worden beschouwd als een variant van psoriasis.

Impetigo herpetiformis is een zeldzame pustuleuze eruptie, die klinisch en histologisch lijkt op een gegeneraliseerde psoriasis pustulosa. De aandoening kan zich ontwikkelen tijdens de laatste maanden van de zwangerschap. Gebieden, bestaande uit een pijnlijk erytheem met vele steriele pustels In de randen breiden zich vanult de flexuren uit over het 1. l.chaam. De algemene toestand is ernstig gestoord met koorts, braken, diarrhee en hypocalciaemie, leidend tot delirium, convulsies en tetanie. Zonder behandeling is de mortaliteit hoog.

\section{2. AETIOLOGIE.}

Psoriasis ils een van de meest voorkomende huidaandoeningen bij mensen met een blanke huid. De morbiditeit bedraagt 1-38 (Farber \& Peterson, 1969; Hellgren,1964, 1967; BraunFalco, 1976). In tropen en sub-tropen zou psoriasis wezenlijk zeldzamer zijn dan in Noord-Europa (Baker,1975; Eckes et a1., 1975$)$.

De psoriasis dispositie is met zekerheid genetisch bepaald 
(Niermann, 1964; Farber et a1.,1974; Hoedemakers, 1975; BraunFalco, 1976). Een bepaalde overervingswijze is evenwel niet met zekerheid vastgesteld. Niet vererfd daarentegen is de leeftija waarop psoriasis zich voor het eerst manifesteert. Psoriasis kan zich ranaf de babyleeftijd (Lerner Lerner, 1972 ) tot op hoge leeftijd voor het eerst manifesteren. Frequent treedt zij voor het eerst op in de tweede (Hellgren, 1967 ) en vijfde (Beckmann et al.,1977) levensdecade.

Behalve bovengenoemde genetische studies pleit tevens voor een genetische determinantie van psoriasis het significant hoger voorkomen van de histocompatibiliteitsantigenen HLA$\mathrm{A} 1, \mathrm{~A} 2, \mathrm{~A} 3, \mathrm{~B} 13, \mathrm{Bw} 16, \mathrm{Bw} 17, \mathrm{~B} 37, \mathrm{Bw} 39, \mathrm{CW} 6, \mathrm{DR} 66$, en DR7 bij psoriasispatienten en hun familieleden (Russel et al., 1972; Svejgaard et a1. ,1974; Karvonen et al.,1975; Krulig et al.,1975; Woodrow et a1.,1975; Guilhou et a1.,1976; Farber \& $C o x, 1981)$. Een verhoogde coincidentie van HLA-B27 en Bw38 en psoriasis arthropathica is tevens wargenomen (Marcusson et al.,1975; Buchanan et a1.,1977). Volgens de onderzoekingen van Beckman et al. (1977) zijn de antigenen HLAB7 en B8 significant verlaagd bij personen met psoriasis.

Milieufactoren beinvloeden de klinische expressie. Kennelijk is er sprake van een multifactorieel lijden (Iombolt, 1963; Watson et a. , 1972, Krueger, 1981). Van de factoren warvan bekend $1 \mathrm{~s}$ dat ze psoriasis precipiteren, is trauma de meest voorkomende. De eerste laesies verschijnen vaak ter plaatse van operatie- of vaccinatielittekens. Maltraiteren van de huid kan uitbreiding van oude of ontstaan van nieuwe laesies tot gevolg hebben. Een dergelijke Koebnerfenomeen kan ook ontstaan na zonneverbranding of andere vormen van dermatitis. In het bijzonder bij kinderen wordt een acute psoriasis van het guttata type voorafgegaan door perioden met tonsilitis of respiratoire infecties. Psoriasis kan worden verergerd door geneesmiddelen, in het bijzonder chloroquine. Systemische toediening van corticosteroiden leidt bij stoppen vaak tot een rebound effect. Een aantal patienten menen dat ex verband bestaat tussen exacerbaties van hun psoriasis en perioden van emotionele onrust.

Ondanks de zeer vele studies die de laatste jaren an een mogelijke pathogenese van psoriasis zijn gewijd (Farber \& Cox,1981; Krueger, 1981) en vele theorieèn over mogelijke ontstaanswijzen van deze aandoening blljft de pathogenese van psoriasis toch nog onbekend. 
In dematologische handboeken worden de histologische veranderingen in de epidermis van een volontwikkelde psoriasislaesie als karakteristiek beschouwd. Deze veranderingen bestaan volgens Lever \& Schaumburg-Lever (1975) uit:

1) Verdikking van de epidermis (acanthose) met verlenging van de rete-lijsten, welke een gevolg is van uitgroei naar buiten en verlenging van de dermale papilien (Van Scott \& Eke1,1963).

2) Verlenging van de dermale papilien. De epidermis boven deze papilien is dunner dan normaal.

3) Het ontbreken van het stratum granulosum.

4) Parakeratotische hyperkeratose.

5) Micro-abcessen van Munro.

In werkelijkheid is de histologie vaak wisselend en niet speciflek voor psoriasis.

Het ontbreken van het stratum granulosum en de aanwezigheid van de parakeratose zijn niet obligatoir voor de gehele psoriasislaesie. Plaatselijk treden parakeratotische haarden op in het overwegend hyperkeratotische stratum corneum (Cox \& Watson, 1972). In de acanthotische epidermis is de plaats van de proliferatieve celpopulatie niet beperkt tot de basale laag, maar verschijnen ook frequent mitosefiguren in de suprabasale cellagen (Van Scott \& Ekel,1963; Fry \& MC Minn, 1970; Penneys et al.,1970). Door verlenging van de rete-1ijsten is de basalmembraan en derhalve ook het oppervlak van de basale laag t.o.v. het epldermisoppervlak vergroot. Uit deze twee gegevens ontstaat een vergroting van het gebied van de proliferatieve epidermis met een factor 4-6 (Van Scott \& Eke1,1963; Rowe, 1966; Christophers \& BraunFalco, 1970).

De basale cellen en hun kernen zijn bij psoriasis groter dan in de normale epidermis. Deze toename in grootte is bij de cellen in het stratum spinosum nog meex uitgesproken (Halprin, 1972). Het cytoplasma is sterker in grootte toegenomen dan de kern (Maxhle, 1975).

De veranderingen in de epidermiscellen worden door sommige auteur's beschouwd als een gevolg van exsudatie en immigratie van leukocyten, leidend tot parakeratose en Munro-abcessen (Pinkus,1965; Suurmond,1965; Pinkus \& Mehregan,1966).

Plnkus (1965) lanceerce het concept dat het afwisselend voorkomen van orthokeratose en parakeratose wordt veroorzaakt door rythmische suprapapillaire exsudatie. Een alternatief pathomechanisme wordt door Neumann (1978) voorgesteld. Deze auteur vindt beschadigde keratinocyten boven de toppen van die dermale papillen warin de capillairen extreem zijn aangetast. Deze capillairverandering leidt tot stasis en daling van de zuurstofspanning. Onvoldoende energievoorziening 
resulteert in een $1 y t i s c h$ proces in de keratimocyten. In beginnende laesies bevinden de beschadigde epidermiscelien zich voornamelijk rond de adnexen en in de bovenste lagen van de epidermis. De rijke bloedvoorziening van het gebled rond de adnexen werkt volgens deze auteur als een sluis voor het transport van histiotoxische stoffen die leiden tot celbeschadiging. De hypoxie en de histiotoxische factoren zouden een focale beschadiging van de epidermiscellen tat gevolg hebben. Deze regressieve epidermale veranderingen leiden tot een reactieve regeneratie van de aaniggende rete-1ijsten. De migratie van leukocyten wordt door Rupec (1970) en Neumann (1974) beschouwd als een necrotactische reactie op epidermale cytolysis.

In de dermale papilien van een psoriasis epidermis is een oedeem warneembaar. Het dermale infiltrat is matig en bestaat uit neutrofiele granulocyten en mononucleaire ce1len (Pinkus \& Mehregan, 1966). Ook Iymphocyten komen in groten getale voor (Braun-Falco \& Schmoecke1,1977).

In het centrum van de laesie is het inflitraat het meest uitgesproken (Soltani et al.,1972), terwijl zich in het overgangsgebied nar de normale epidermis een veel geringer infiltraat bevindt, dat overwegend uit macrofagen en mestcellen bestaat (Braun-Falco \& Burg.,1970).

Uit de dermale papilien migreren serumeiwitten en leukocyten naar de epidermis. Deze zich op omschreven plaatsen verzamelde polymorf-kernige neutroflele leukocyten geven aanleiding tot de vorming van Munro-abcessen in het stratum corneum. Los hilervan bevinden zich in de verbrede epidermis altijd intercellulair enkele macrofagen, neutrofiele leukocyten en mestcellen.

In de papillen van actieve psoriasislaesies zijn de capillairen sterk verlengd en verwijd (IIIig,1966). De capillaire veranderingen nemen van de rand naar het centrum van de laesie toe (Wohlrab, 1963; Beek \& Van Reede, 1977). De endotheelcellen van deze capillairen geven een sterke stijging van de glycolytische en hydrolytische enzymactiviteit te zien (Herrman et a1.,1962; Braun-Falco \& Burg, 1970). De capillaire doorlaatbaarheid is verhoogd (Baker, 1975). Deze capillairveranderingen gaan tijdens de therapeutisch geinduceerde genezing van de laesle slechts zeer langzaam terug (Braun-Falco et al.,1971). Of de capillairveranderingen voorafgaan an de psorlasislaesie (Madden, 1941) of hiervan een gevolg zijh als aanpassing aan de toegenomen stofwisselingsbehoefte (Braun-Falco, 1976) is tot op heden niet opgelost (Greither, 1977). Ook de vraag of het ontstekingsinflitraat in de dermis oorzaak of gevolg van de epidermale veranderingen is, is nog nlet met zekerheld beantwoord.

Bij electronenmicroscopisch onderzoek blijkt de meest wezenlijke verandering in de psoriasiscellen de cytolysis van de keratinocyten van het stratum spinosum te zijn. Deze cytolysis begint perinucleair. De penetratie van leukocyten is secundair (Rupec, 1970). In de basale keratinocyten is het 
aantal mitochondria sterk verhoogd. Tonofilamenten en desmosomen zijn schaars in het onderste deel van de epidermis, terwijl deze in het bovenste deel van het stratum spinosum sterk zijn toegenomen. zij hebben dan echter weI een abnormale vorm (Fischman et al.,1977). De intercellulaire ruimte is verbreed. Deze verbreding berust op intercellulair oedeem en vermindering van intercellulaire contactzone (Weinstein \& McNutt, 1972; Rupec,1970; Mahrle,1975). De op het celmembraan van de keratinocyten aanwezige microvili zijn bij psoriasis sterk verlengd (Gommans et a1.,1979). De hoeveelheid materiaal van de basale lamina is voornamelijk in oude laesies toegenomen, terwijl in actieve laesies een groot aantal openingen in de basale lamina zijn waardoor epldermaal cytoplasma in de dermis uitpuilt (Brody, 1962; Cox, 1969). In het karyoplasma van capiliaire endotheelcellen, flbroblasten en in geringere mate van macrofagen en keratinocyten is een verhoogd aantal insluitlichaampjes die glycogeen en lipiden bevatten, gevonden. Deze insluitlichampjes zijn niet specifiek voor psoriasis (Bork et $a 1 ., 1975)$.

1. 4. EPILOOG.

Het hiexboven beschrevene aangaande het ziektebeeld psoriasis pretendeert geenszins volledig te zijn. Psoriasis mag zich verheugen in een zeer grote belangstelling van onderzoekers van uiteenlopende disciplines. Het zou te ver voeren hier in het kader van dit proefschrift te streven naar een volledig overzicht, indien dit al mogelijk zou zijn daar gedurende de laatste 10 jaar meer dan 3200 artikelen met "psoriasis" in hun titel zijn vermeld in de Index Medicus. Er is getracht slechts een beperkt en beknopt overzicht van dit zlektebeeld te geven teneinde de niet met psoriasis bekend zijnde lezer enlig inzicht in deze aandoening te verschaffen.

Ondanks het soms zeer klassieke klinische beeld van psoriasis komt het bepald niet zelden voor dat de diagnose op grond van de klinjsche efflorescenties slechts met moejte gesteld kan worden. Deze problemen bij het stellen van de diagnose en de tevens bestaande onzekerheid op histologisch gebied maken het wenselljk dat een nieuwe parametex in de vorm van flowcytometrie voor de diagnostiek van psoriasis beschikbaar komt. 
1. 5. REFERENTIES.

Alkiewicz, J.: Psoriasis of the nail. Br. J. Derm.,60:195200,1948 .

Baker, H.: Psoriasis: A review. Part I-II. Dermatologica, $150: 16-25,136-153,1975$.

Beckman, L., Bergdahl, K. , Cedergren, B. \& Iiden, S.:Genetic markers in psoriasis. Acta Dermatovener, 57:247-251, 1977.

Beek, C.H. van Reede, E.C.: The nature and frequency of the histological changes found in psoriasis vulgaris. Arch. Derm. Res. , 257:255-264, 1977 .

Binazzi, M., Calandia, P. \& Lisi, P.: Statistical association between psoriasis and diabetes. Arch. Derm. Res.,254: $43-49,1975$.

Bork, K., Holzmann, H. \& Bierther, M.: Zur Ultrastruktur der Kerneinschlüsse von Bindegewebszellen in Psoriasisherd. Arch. Derm. Res.,253:85-90,1975.

Braun-Falco, O.: Neuere Aspecte zur Pathogenese der Hauterscheinungen bei Psoriasis vulgaris. Hautarzt, $27: 363-374$, 1976.

Braun-Falco, O. \& Burg, G.: Das entztindliche Infiltrat bei Psoriasis vulgaris. Arch. klin. exp. Derm.,236:297-314, 1970.

Braun-Falco, O. \& Burg, G.: Zur Histochemie der Capillairen bei Psorlasis vulgaris. Arch. klin. exp. Derm.,236:173-189, 1970 .

Braun-Falco, O. , Burg, G. \& Schgefinius, H.H. : Ueber die wirkung von Dithranol (Cignolin ) bel Psoriasis vulgaris. Arch. Derm. Forsch.,241:217-236,1971.

Braun-Falco, O. Schoecke1, C.: The dermal inflammatory reaction in initial psoriatic lesions. Arch. Derm. Res., $258: 9-16,1977$.

Brody, I.: The ultrastructure of the horny layer in normal and psoriatic epidermis as revealed by electron microscopy. J. Invest. Derm. $39: 519-528,1962$.

Buchanan, R. , Kraag, G., Rosenthal, D. \& Singa1, D.P.: HLA Antigens and psoriatic arthritis. Transplantation Proceedings, vol 9, no 4 (december), 1977.

Buchner, A. \& Begleiter, A.: Oral lesions in psoriatic patients. Oral Surg., $41: 327-332,1976$. 
Burch, P.R.J. Rowell, N.R.: Psoriasis: aetiological aspects, Acta Derm. vener.,45:366-380, 1965.

Christophers, E* Braun-Falco, O. : Psoriatic hyperplasia: some measurements. Br. J. Derm. 83:63-68,1970.

Comaisch, S.: Autoradiographic studies of hair growth in various dermatoses. Br. J. Derm., $81: 283-288,1969$.

Cox, A.J.: The dermal-epidermal junction in psoriasis. J. Invest. Derm. $53: 428-435,1969$.

Cox, A.J. Watson, W.: Histologic variations in lesions of psorlasis. Arch. Dermatol.,106:503-506,1972.

Eckes, L. Ananthakrishnan, R. \& Walter, H.: Zur geografischen Verteilung der Psoriasis. Hautarzt, 26:563-567, 1975 .

E1-Zawahry, M.: Mucosal and lingual psoriasis. Arch. Dermato $1 ., 108: 275,1973$.

Farber, E.M. \& Cox, A.J.: psoriasis, proceedings of the third international symposium, pag. 285-291, 1981 .

Farber, E.M., Na11, M.L. \& Watson, W.: Natural history of psoriasis in 61 twin pairs. Arch. Dermato1.,109:207-211, 1974.

Farber, E.M. \& Peterson, J.B.: Variations in the natural history of psoriasis. Calif. Med.,95:6-11,1969.

Fischman, S.I., Barnet, M.I. \& Nisengard, R.J.: Histopathologic, ultrastructural and lmmunologic findings in an oral psoriatic lesion. Oral Surg.,44:253-260,1977.

Fry, L. \& MC Minn, R.M.H.: Observation on mitosis in psoriatic epidermis. Br. J. Derm., 82:19-22, 1970 .

Ganor, S.: Diseases sometimes associated with psoriasis 1 and 2.: Dermatologica, $154: 268-272$ and $338-341,1977$.

Gommans, J.M., Bergers, M., van Exp, P. "van den Hurk, J., Mier, P.D. Roelfzema, H.: Studies on the plasma membrane of normal and psoriatic keratinocytes. Br. J. Derm.,101: $407-412,1979$

Greither, A.: PSoriasis: Eine Allgemeinkrankheit ?. Hautarzt, $28: 5-9,1977$.

Guilhou, J.J., Meynadier, J., Clot, J., Charmasson, E., Dardenne, M. Brochier, J.: Immunological aspects of psoriasis. Br.J. Derm., 95:295-301,1976.

Halprin, K.M.: Epidermal "turnover time"- a re-examination. Br. J. Derm. ,86:14-19,1972. 
Hel1gren, $L_{*}$ : Psoriasis. Statistical, clinical and laboratory investigation of 255 psoriatics and matched healthy controls. Acta Dermatovener. (Stockholm), 44:191-207,1964.

Hellgren, I.: Psoriasis in total population in sweden. Almquite Wiksel, stockholm, 1967.

Herrman, F., Steigleder, G.K., Kamei, X. \& Kim, J.H.: Aminopeptidasen-Aktivitat in der psoriatischen papel. Derm. Wschr., $146: 603-609,1962$.

Hoedemakers, H.C.M.: Statistisch-genetische analyse van atopie en psoriasis. Proefschrift Nijmegen, 1975.

Illig, L.: Die Morphogenese der Blutgefäss-Reaktion bei der Psoriasis vulgaris. Arch. klin. exp. Derm.,227:151-158,1966.

Ingram, J.T.: The significance and management of psoriasis. BI. Med. J., 11:823-835, 1954 .

Karvonen, J. , Tillikainen, A. \& Lassus, A.: HLA-antigens in patients with persistent palmoplantar pustulosis and pustular psoriasis. Ann. Clin. Res., 7:112-115,1975.

Koebner, H.: Zur Aethiologie der Psoriasjs. Vjschr. Derm. Syph., 4: 203-207,1877.

Krueger, C.C.:psoriasis: current concepts of its etiology and pathogenesis. in: Year book of dermatology 1981, blz $13-70,1981$.

Krulig, L., Farber, E.M., \& Grumet, F.C.: Histocompatibility (HL-A) antigens in psoriasis. Arch. Dermato1., 111: $857-860,1975$.

Lerner, M.R. \& Lerner, A.B.: Congenital psoriasis. Arch. Dermatol. , 105:598-601,1972.

Lever, W.F. \& Schaumburg-Lever, G.: Histopathology of the skin. J.B. Lippincott Philadelphia-Toronto, 1975.

Lewin, K., De Wit, S. \& Ferrington, R.A.: Pathology of the finger nall in psoriasis. Br. J. Derm.,86:555-563,1972.

Lombolt, G.: Psoriasis prevalence, spontaneous course, and genetics: a census study on the prevalence of skin diseases on the Faroer Islands. Copenhagen, G.E.C. GAD, 1963.

Madden, J.F.: Histologic studies of uninvolved skin of patients with psoriasis. Arch. Derm. Syph.,44:655-664,1941.

Mahrle, G.: Psoriasis vulgaris. Cytologie und Cytochemie einer benignen Epidermisproliferation. Proefschrift Götingen, 1975 . 
Marcusson, J., MOLlex, E. Thyresson, N.: HL-A antigens (17, 27 UPS) in psoriasis with special reference to patients with arthritic lesions. Acta Dermatovener. (stockholm), 55:297-300, 1975.

Mol1, J.M.H.: The Clinical spectrum of psoriatic arthritis. Clin. Orthop.,143:66-75, 1979 .

Mom, A.M. , Polak, M., Fabeiro, J.L. Garibaldi, I.B.: The psoriatic myopathy, Diermatologica, 140:214-218, 1970.

Wiermann, H.: Neue Exgebnisse der zwillingspathologischen Forschung. Arch. ki1n. exp. Derm. 219:378-392,1964.

Neumann, E*: The nature and role of epidermal regressive changes in the development of the psoriatic lesion. Acta Dermatovener. (Stockholm), 58:481-486,1978.

Neumann, E. \& Hard, S.: The significance of the epidermal sweat duct unit in the genesis of pustular psoriasis (Zumbusch) and the micro-abcess of Munro-Sabouraud. Acta Dermatovener. (Stockholm), 54:141-146,1974.

Novotny, F.: Liver changes in psoriasis. In: Psariasis, proceedings of the third International symposium, pag. 327328,1981 .

Oppenheim, M.: Psoriasis mucosae orls. Monatsschr. Prakt. Dexmato $1 ., 37: 481-483,1903$.

Orfanos, C., Mahrle, G. \& Christemhusz, R.: Verhornungsstörungen arm Haar bei Psoriasis. Arch. klin. exp. Derm., $236: 107-114,1970$.

Penneys, N.S., Fultom, J.E., Weinstein, G.D. \& Frost, P.: Location of proliferating cells in human epidermis. Arch. Dermatol., 101:323-327,1970.

Pinkus, H.: Psoriasiform tissue reactions. Australias J. Derm. , $1: 31-35,1965$.

Pinkus, H. Mehregan, A.H.: The primary histologic lesion of seborrhoeic dermatitis and psoriasis. I. Invest. Derm." $46: 109-116,1966$.

Rowe, I.: Volume of epldermis and dermal papillae in psoriasis, actinic keratoses and lentigo. J. Invest. Derm." $46: 374-377,1966$

Rupec, M.: Zur U1trastruktur der spongiform Pustel. Arch. kin. exp. Derm.,239:30-49,1970.

Russe1, T.J., Schultes, L.M. \& Kuban, D.J.* Histocompatibility (HL-A) antigens associated with psoriasis. New Engl. J. Med.,287:738-740, 1972. 
Soltani, K. \& tan Scott, E.J.: Patterns and sequence of tissue changes in incipient and evolving lesions of psoriasis. Arch. Dermatol., 106:484-490,1972.

Suurmond, D.: Histologic changes in treated and untreated psoriatic lesions. Dermatologica, $131: 357-366,1965$.

Svejgaard, A., Nielsen, L.S. , Svejgaard, E., Nielsen, F.K., Hjortshoj, A. Zachariae, H.: HL-A in psoriasis vulgaris and in pustular psoriasis - population and family studies. Br. J. Derm. , 91:145-153,1974.

Van Scott, E.J. \& Ekel, T.M.: Kinetics of hyperplasia in psoriasis. Arch. Dermatol., 88:373-381, 1963 .

Watson, W. Cann, H.M. , Farber, E.M. \& Na11, M.L.: The genetics of psoriasis. Arch. Dermatol., 105:197-207,1972.

Weinstein, G.D. \& MC Nutt, H.: Cell junctions. New Engl. Med. J., 286:521-524,1972.

WohIrab, W.: Ueber die Histotopographie der Phosphomonoesterasen im Psoriasisherd und dessen Umgebung. Arch. klin. exp. Derm.,217:471-479,1963.

Woodrow, J.C., Dave, V.K., Usher, N. \& Anderson, J.: The HL - A system and psoriasis. Br. J. Derm.,92:427-436,1975.

Wyatt, E., Bottoms, E. \& Comaish, S.H.: Abnormal hair shafts in psoriasis on scanning electron microscopy. Br. J. Derm. , 87:368-373,1972. 
HOOFDSTUK 2.

LITERATUUROVERZICHT VAN DIVERSE METHODEN TER BESTUDERING VAN DE CELPROLIFERATIE VAN NORMALE EN PSORIASIS EPIDERMIS.

2.1. Inleiding

2.2. Radioactief gemerkte aminozuren

2.3. Kleurstofien

2. 4. Histogeometrie

2.5.1. Mitotische index

2.5.2. Mitotische index na stathmokinetische stoffen

2.6. Autoradiografie

2.6.1. Inleiding en methoden

2.6.2. Labelling index.

2.6.3. Volgen van gemerkte cellen op hun weg door de diverse compartimenten van de epidermis

2.6.4. Fraction labelled mitosis curwe

2.6 .5 . Dubbele labelling methode

2.6 .6 . Continue labelling methode

2.6.7. Tellen van granulae

2.7. Scintillatie telling

2.8. Cytofotometrie

2.8.1. Statische cytometrie

2.8.2. Elowcy tometrie

2.9. Samenvatting en discussie

2.10. Referenties 
LITERATUUROVERZICHT VAN DIVERSE METHODEN TER BESTUDERING WAN DE CELPROLIFERATIE VAN NORMALE EN PSORIASIS EPIDERMTS.

2.1. INLEIDING.

De celproliferatie is sedert decennia onderwerp van intensieve research geweest met het doel een beter inzicht te krijgen in de fysiologie van normale en pathologische celreproductie. Een van de grootste celreproductie systemen in het menselijk lichaam is de epidermis. Deze kan men schematisch voorstellen als bestaande uit drie compartimenten. De klassieke theorie aangaande de wijze warop, onder normale omstandigheden, de epidermale regeneratie geschiedt is in 1927 door $F$. Pinkus voorgesteld: Het cellulaire materiaal dat an het oppervlak van het stratum corneum verloren gaat wordt vervangen door nieuwe cellen die in de basale laag door deling van de daar anwezige cellen ontstaan (zie H. Pinkus, 1952).

Celdeling en derhalve celproductie vindt plats in de basale en suprabasale cellagen (proliferatieve celpopulatie, compartiment 1). De huidige kennis van de celproliferatie is gebaseerd op het concept van de celcyclus (Howard Pelc, 1953). De celcyclus wordt gedefiniëerd als het interval tussen de voltooling van de mitose in een cel en het einde van de telophase van de volgende mitose in een dochtercel. Tijdens de celcyclus doorloopt de cel een antal. stadia, warin karakteristieke biochemische veranderingen plaatsvinden (Baserga,1968,1971). De celcyclus wordt verdeeld in vier fasen: de $G_{1}$ fase, $S$ fase, $G_{2}$ fase en de mitose fase.

De $G_{1}$ fase is het interval tussen de voltooling van de mitose en het begin van de DNA synthese. In deze periode worden ribonucleinezuren en proteinen voor de komende DNA replicatie gesynthetiseerd (Baserga,1968). Cellen in de $G_{1}$ fase zijn gekenmerkt door een diploide hoeveelheid DNA van de kern (2C DNA). Het absolute DNA gehalte van normale $G_{4}$ fase cellen is voor een ind 1 vidu constant (Vendrely, 1971). De $S$ fase is de periode warin de replicatle van het chromosomale DNA plaatsvindt. Doordat synthese van DNA alleen in deze fase van de celcyclus platisvindt kunnen cellen in de $S$ fase herkenbaar gemaakt worden door inbouw van DNA-precursors. S fase cellen hebben een DMA gehalte van de kern dat 11 gt tussen 20 en $4 \mathrm{C}$ DNA, afhankeijjk van het feit hoever de duplicatie van de chromosomen is voortgeschreden (Vendrely, 1971).

De $G_{2}$ fase is de post-synthetische pre-mitotische periode. De DNA synthese is voltooid en cellen in de $G_{2}$ fase zijn tetraploid (4c DNA). In deze fase vindt synthese van RWA en proteinen ter voorbereiding van de mitose plaats (Iipkin, 1971). 
De $M$ fase: de mitose fase is onderverdeeld in prophase, metaphase, anaphase en telophase. De mitose fase is microscopisch te herkennen door condensatie en scheiding van de chromosomen. Cellen in de mitose fase zijn tetraplold.

Figuur 2.1.1. geeft een schematische voorstelling van de hoeveelheld DNA wan de kern van een cel die de celcyclus door loopt.

Figuur 2.1 .1 .

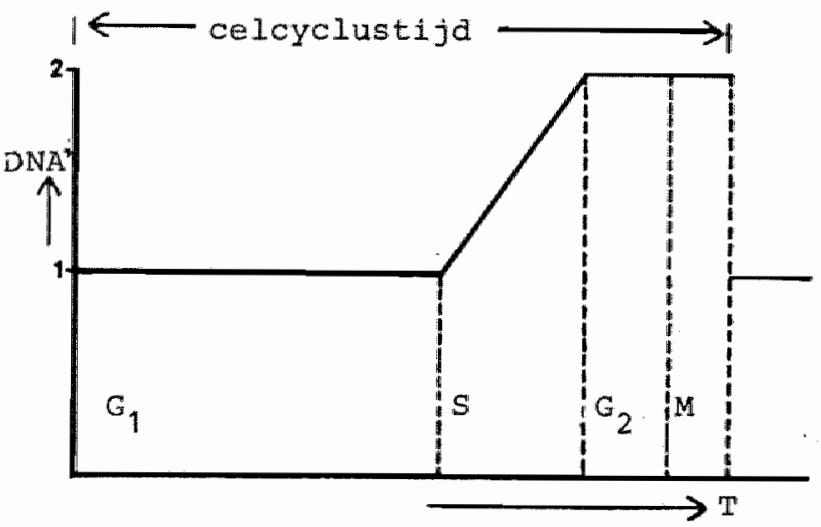

Figuur 2.1.1.: Schematische voorstelling van de hoeveelheid DNA van de kern van een cel die de celcyclus doorloopt.

Nadat in de epidermis de celdeling is voltooid kan de nieuwgevormde basale cel opnieuw gaan prolifereren en wederom actief de celcyclus doorlopen of migreren naar het stratum spinosum, waarbij differentiatie optreedt en het vermogen tot proliferatie verloren gat. De nieuwgevormde basale cel kan ook overgaan in een rustfase waarbij het vermogen tot celdeling behouden bijjft. Deze fase wordt $G_{0}$ fase genoemd (Epifanova, 1969; Gelfant, 1976). Gelfant (1976) introduceerde het concept dat er in de epidermis twee categorieën niet circulerende $G_{0}$ celien zijn. De eerste categorie zou geblokkeerd zijn in de $G$ fase van de celcyclus, de tweede categorie in de $G_{2}$ fase. Cellen in de $G_{0}$ fase kummen na een specifieke stimulus terugkeren in de proliferende populatie. Voor de basale laag van de muze-epidermis wordt het andeel van de $G_{0}$ cellen op 10-20: geschat (Potten, 1975). Van de humane epidermis is de grootte van de $\mathrm{G}_{0}$ fractie niet met zekerheid bekend (Pullmann, 1978).

Een deel van de cellen in de prolifererende populatie migreren naar de rete Malpighi (compartiment 2 ). Tijdens dit migratieproces differentieren de cellen en verliezen hiermee het vermogen tot reproductie. Het derde compartiment van de epidermis is het stratum corneum (hoornlaag). In histologische coupes is dit compartiment gekenmerkt door verlies van cellulair detall, de afwezigheid van de kern of kernresten en door afplatting van de cellen. De hoornlaag is niet in staat metabole activiteiten, die karakteristiek 
zijn voor de levende epidermiscellen, te ontploolen en wordt derhalve beschouwd als het niet-levende eindproduct van de epidermale celdifferentiatie.

De turnovertijd van een weefselcompartiment is de tijd die nodig is om alle cellen van dat compartiment te vervangen, ofwel door influx, ofwel door mitose, of door beide. Wanneer alle cellen van een compartiment prolifereren en ex geen influx is, is de turnovertijd gelijk aan de celcyclustijd. Voor een compartiment zonder celdeling en met een uniforme beweging in en uit het compartiment is de turnovertija gelijk aan de transittijd. De transittijd is de tijd die een cel nodig heeft om een compartiment te doorlopen. Onder de proliferatie-snelheid (birth rate = proliferation rate) wordt verstaan de celproductie per cel of per compartiment.

Het onderzoek naar de celkinetische aspecten van normale en pathologisch veranderde epidermiscellen kan aan elk van deze compartimenten worden uitgevoerd. Celkinetische informatie op het niveau van de celcyclus van de prolifererende celpopulatie wordt verkregen door het bepalen van de mitotische index, al dan niet na stathmokinesis, bepaalde autografische methoden en de cytometrische methoden. Door toediening van radioactief gelabelde aminozuren kan men de turnovertijd van het levend epitheel en het stratum corneum bepalen. De turnovertijd van compartiment 1 en 2 kan men onderzoeken door toediening van radioactieve DNA-precursors. De turnovertijd wan het stratum corneum kan worden bepaald door applicatie van kleurstoffen op de huid. Indirect kan op deze wijze ook inzlcht worden verkregen in de celproliferatie van het onderliggende levende epitheel. De histogeometrie is een op zichzelf staande benaderingswijze warbij dynamische aspecten met histologische methoden worden bestudeerd.

Naast bovengenoemde bestaan er nog meerdere celkinetische parameters die m.n. in de tumorresearch worden gebruikt. Daar deze buiten het kader van dit proefschrift vallen worden zij hier niet besproken. In dit hoofdstuk wordt een overzicht gegeven van verschillende celkinetische methoden om inzicht te krijgen in de wijze warop de weefsel-en celreproductie van de normale en psoriasis epldermis zich afspeelt. 
De turnovertija van het stratum corneum en van het levend epitheel is door Rothberg et al. (1961) onderzocht met, gehulp van radioactief glycine. Na $i . v$. toediening van $c^{4}$ glycine treedt, nadat het aminozuur via diffusie in de epidemis is gekomen, inbouw op in de proteinen van de epidermiscellen. Met behulp van chromatografie bepaalden deze auteurs de hoeveelheid glycine in schraapsels van normale en psoriasis epidermis als functie van de tijd. Vervolgens werd de specifieke activiteit bepald.

De schraapsel vam normal stratum corneum verschijnt het eerste proteine dat gelabeld glycine bevat 14 dagen na de initiele incorporatie. De maximale specifieke activiteit wordt vervolgens zinchtbaar als een scherpe piek op de 26-28 dag. In de proteinen van psoriasis-schilfers vertoont het geisoleerde glycine een maximale specifieke activiteit op de derde dag (Rothberg et al.,1961).

Bovengenoemde auteurs baseren op deze gegevens een turnovertijd voor het stratum corneum van 14 dagen en een turnovertijd van 28 dagen voor de gehele normale epldermis. Hierbij gaan Rothberg et al. ervan uit dat het gelabelde glycine als een scherpe band in de basale laag wordt geincorporeerd. Gezien de verschillen in piekactiviteiten na intradermale injectie van gelabeld glycine en methionine (Porter s shuster, 1967 ) en de bevinding van Fukuyama et al. (1965) dat glycine voornamelijk in de bovenste cellagen van de levende epidermis wordt ingebouwd, lijkt deze veronderstelling onjuist.

Deze turnovertija van 14 dagen voor het normale stratum corneym is door porter \& shuster $(1967)$ eveneens met behulp van $C^{4}-$ glycine en door Frost et al. (1966) met behulp van $\mathbf{H}^{3}-$ glycine bevestigd.

\subsection{KLEURSTOFFEN.}

De turnovertijd van het stratum corneum is met behulp van kleurstoffen voor het eerst bepaald door sutton. Na de hoornlaag met zllvernitrat gekleurd te hebben bepaalde hij de tljd die nodig was voor het verdwijnen van de kleurstof (sutton, 1938).

Baker \& Kligman (1967) gebrulken tetrachloorsalicylanilide (TCSA), een fluorescerende kleurstof, die nog in zeer kleine hoeveelheden door het menselijk oog onder woods licht kan. worden gezien en die alleen het stratum corneum kleurt, doch het levend epitheel niet binnendringt. De turnovertija van het stratum cormeum is rechtevenredig met het aantal cellagen van het stratum corneum. Aan de andere kant is deze turnovertijd omgekeerd evenredig met de productie onder een bepaalde oppervlak.

Baker \& Kligman (1967) vinden een turnovertijd van 15 dagen woor het stratum corneum van een normale epidermis op de rug. zij berekenen tevens dat er, op grond van het aantal cellagen 
en de turnovertijd van het stratum corneum, geen productieverschillen zijn tussen rug, arm en abdomen. Het voorhoofd daarentegen vertoont een hogere productie. TCSA kleurt eveneens snel de parakertotische hoornlaag bij psoriasis. Bij psoriasis verdwijnt de fluorescentie binnen $2-4$ dagen (Baker \& Kigman, 1967).

Bij het beoordelen van deze cijfers moet rekening worden gehouden met het feit, dat zowel zilvernitrat als TCSA sterk irriterende stoffen zijn, waardoor zij de mitotische activiteit van de epidermis vergroten (Pinkus, 1952; Brophy \& Lobitz, 1959 ).

Met dansylchloride, een niet irriterende fluorescerende kleurstof, berekenen Jansen et al. (1974) een turnovertijd van 1215 dagen voor normal. stratum corneum. Voor het voorhoofd bedraagt deze tijd ruim acht dagen. Een versnelde turnovertijd voor de hoornlaag van de hoofdhuid wordt ook gevonden door Plewig et al. (1971). Op oudere leeftijd is de turnovertijd volgens Baker \& Blair (1968) verlengd, doordat de productie per tijdseenheid vertraagd is.

Uitgaande van bovengenoemde turnovertijd van het stratum corneum berekenen Bergstresser \& Taylor (1977) de turnovertijd van de levende epidermis. Hiertoe bepalen zij het aantal cellagen van het stratum corneum, de oppervlakte van een corneocyt en het aantal keratinocyten onder $1 \mathrm{~mm}^{2}$ huid. Op deze wijze berekenen zij een turnovertijd voor de levende epidermis van 31 dagen.

Deze benaderingswijze heeft het nadeel dat eventuele fouten in de parameters met elkaar worden vermenigvuldigd. Wanneer wij echter, uitgaande van de door Bergstresser \& Taylor (1977) bepalde turnovertija van 31 dagen voor de totale levende epidermis een verhouding proliferatieve tot non-proluferatieve cellen van $2,2: 1$ (Halprin, 1972) aannemen, bedraagt de celcyclustijd van de proliferatieve celpopulatie 236 uur. Deze waarde ligt binnen het spreidingsgebied van celcyclustijden, zoals deze, berekend met andere methoden, in de literatuur worden vermeld.

\section{4. HISTOGEOMETRIE.}

Een geheel andere benaderingswijze van de celkinetische problematiek van normale en psoriasis epidermis is gekozen door Van Scott \& Ekel (1963). Via directe planimetrische metingen in serle-coupes onder het microscoop berekenden $z$ if dat het volume epidermis per eenheid opperviakte van het hutdoppervlak bij psoriasis ruim 4 mal het volume van normale epidexmis was. Tevens was volgens deze auteurs het aantal mitosen per eenheid huidoppervlak bij psorlasis 27 mal zo groot als in normale epidermis. Deze toename van het aantal mitosen berust op de vergroting van het basale membraan oppervlak ten gevolge van de uitgroei van de dermale papilien. Bovendien speelt het voorkomen van mitosen in meerdere cellagen van de 
epldermis dan bif normale huld het geval is een belangrijke rol.

Ultgaande van de door Rothberg et al. (1961) berekende turnovertijd van 28 dagen voor normale epidermis berekenen Van Scott Ekel een turnovertija voor de epidermis bij psoriasis van 4 dagen.

De berekening van Van Scott \& Ekel is, afgezien van mogelijke methodieke fouten, onjuist omdat de door Rothberg et al.

(1961) beschreven 28 dagen betrekking hebben op de turnovertijd van het stratum corneum (14 dagen) en de levende epidermis (14 dagen). Op grond van de gegevens wan van Scott \& Ekel zou de turnovertija van de epldermis bij psoriasis dan ruim 2 dagen bedragen. Deze 2 dagen zijn tenslotte alleen juist indien de celcyclustijd van de psoriasiscel gelijk is aan die van de normale epidermiscel.

Van Scott Ekel (1963) vinden bovendien een proportionele relatie tussen de grootte van de dermale papilien en de grootte van de populatie prolifererende cellen boven deze papillen. Deze relatie blijft behouden als de dermale papilien bij psoriasis groter worden.

\subsubsection{MITOTISCHE INDEX.}

De mitose is microscopisch te herkennen door condensatie en schelding van de chromosomen tijdens de prophase, metaphase, anaphase en telophase. De mitotische index (M.I.) is het aantal mitosen in de basale celpopulatie gerelateerd aan het totale aantal in de interfase verkerende basale cellen of aan het totale aantal levende epidermiscellen. De methode waarbij het aantal mitosen per eenheid lengte van de basale membraan wordt geteld is minder gewenst (Wright, 1977). De mitose snelheid is de M.I. per tijaseenheid.

Het meermalen tellen van dezelfde nucleus in diverse coupes kan net de formule van Abexcrombie (1946) worden gecorrigeerd. Het microscopisch herkenmen van late telophase-cellen en "clear cells" van Masson kan moeilijk zijn. zo kunnen ook vroege prophase cellen soms moeilijk te onderscheiden zijn van gegranuleerde nuclei (Fisher Wells, 1968). Bovengenoemde foutenbronnen, de arbeldsintensiviteit van het onderzoek en de subjectiviteit van de onderzoeker zijn de grootste nadelen van de methode. De M.I. methode wordt het meest toegepast wanneer relatueve metingen gewenst $z i j n, b, v, b i j$ het vergelijken van de invloed van diverse stoffen op de turnovertijd van de epldermis.

Voor normale humane epldermis geeft tabel 2.5.1. een overzicht van diverse celkinetische data, zoals die door diverse auteurs met behulp van de M.I. methode zijn gevonden. De turnovertijd van de levende epldermis kan worden berekend ult de M.I. en de duur van de miltosefase. 
Tabe1 $2.5 \cdot 1$.

AUTEUR

M.I.

T. T.

PLAATS

\begin{tabular}{|c|c|c|c|}
\hline \multirow[t]{2}{*}{ Thuringer, 1928} & 0,04 & - & hoofd \\
\hline & 0,4 & - & preputium \\
\hline Cooper, 1939 & $0,15-0,68$ & - & preputium \\
\hline Hoffman, 1949 & 0,01 & 257 & $\operatorname{arm}$ \\
\hline Pinkus, 1952 & 0,16 & 26,7 & onderarm \\
\hline \multirow[t]{2}{*}{ Katzberg, 1952} & 0,02 & 100 & abdomen \\
\hline & 0,16 & 13 & onderarm \\
\hline Brophy \& Lobitz, 1959 & 0,08 & - & rug \\
\hline Fisher, 1968 & $0,01-0,09$ & - & - \\
\hline Rowe et a1.,1978 & $0,15-0,24$ & - & - \\
\hline
\end{tabular}

Tabel 2.5.1.: Overzicht van een aantal in de literatuur opgegeven waarden voor mitotische index (M.I.) in procenten en turnovertijd (T.T.) in dagen van normale humane eplidermis voor enkele plaatsen op het 1ichaam.

De met behulp van de M.I. berekende turnovertijaen voor normale epidermis variëren van 13 (Katzberg,1952) tot 257 (Hoffmann, 1949) dagen afhankelijk van de gevonden mitotische indices en de geschatte mitoseduur. De in de literatuur opgegeven waarden voor de M.I. zijn niet zonder meer met elkaar te vergelijken, omdat niet alle auteurs het aantal getelde mitosen relateren an dezelfde celpopulatie.

De M.I. van een psoriasislaesie is sterk verhoogd (Fisher, 1968; Weinstein \& Forst, 1968; Fry \& McMinn,1970; Kaldby \& Kurban, 1971). Er bestaan aanzienlijke verschillen in mitose aantal tussen diverse psoriasis patienten (Fry \& McMinn, 1968). De spreiding tussen de patienten is echter significant groter dan de spreiding tussen divexse plaatsen op het lichaam bij dezelfde patient (Fry \& McMinn, 1970).

over het al dan niet bestaan van schommelingen in de M.I. in de loop van de dag (Diurnal variantion) heexst geen eensluidende opinie.

Milstein \& Cornel (1973) alsmede Fry \& MMinn (1973) vinden deze variatie noch in normale epidermis noch bij psoriasis. Cooper (1939), Scheving (1953) en Fisher (1968) vinden een piek in mitotische activiteit van een normale epidermis in de ochtenduren terwijl Rowe et al. (1978) vinden dat het antal mitosefiguren in normale epidermis 's middags hogex is dan's ochtends. Hell \& Hodgson (1966) en Pullmann et a1. (1974) vinden daarentegen geen variaties in de normale echter wel in de psoriasis epidermis. 
Colchicine blokkeert de in de mitosefase verkerende cel in de metaphase (Dustin, 1936; Brues, 1936; Ludford, 1936; Bucher. 1939), terwijl de cellen niet worden gehinderd de mitose te beginnen. Ex treedt geen interferentie op met cellen in de prophase, noch is er enige invloed op de duur van de prophase, terwijl alle cellen in de metaphase worden geblokkeerd (Stevens-Hooper, 1961). Colchicine werd aanvankeiljk gebruikt om de plats van de normale celdeling te onderzoeken. Vervolgens is colchicine toegepast bij het onderzoek naar de mate van proliferatie van het damepitheel van ratten (Leblond \& stevens, 1948 ) en katten (McMinn, 1954), alveolicelien (Bertanlanffy Leblond, 1953 ) en blaasepitheelcellen (Vulpé, 1954).

De mate van toename van de in de metaphase geblokkeerde $\mathrm{M}_{\text {. I. }}$ per tijdseenheid wordt "mitotic rate" genoema (Stevens-Hooper, 1961). Uit de combinatie van M. I. en mitotic rate is met de stevens-Hooper formule de duur van de mitosefase te berekenen.

Fisher Wells (1968) vinden een mitotic rate, gemeten over een tijdsbestek van vijf uur, van 1,2 resp. 1,4 mitosen per 9000 levende epidermiscellen in de normale epidermis wan volwassen vrouwen resp. mannen. Hierult berekenen zij een mitoseduur van ongeveer 90 minuten. De epidermale mitotic rate in psoriasislaesies is 3-4 mal groter dan in normale epldermis De duut van de mitosefase van een psoriasiscel bedraagt volgens deze auteurs ongeveer vier uur vergeleken met de $1 \frac{1}{2}$ uur van een normale epidermiscel (Fisher \& WeI1s, 1968).

Vincristine sulfaat (Oncovin ${ }^{\mathbb{R}}$, geeft in een dosering van 1 ag intradermaal eveneens een optimale blokkade in de metaphase, zonder dat er een belangrijk toxisch effect van vincristine op de delende cel optreedt (Duffil1 et a 1.,1977). De mitotic rate van epidermiscelien in een psoriasislaesie bedraagt volgens Duffill et al. (1976), gemeten over een periode van $2 \frac{1}{2}$ uur, 13 cellen per 1000 germinatieve cellen per uur. Hieruit berekenen deze auteurs een metaphaseduur van 30 minuten, terwijl de duur van de totale mitose 37 minuten zou bedragen.

De twee bovengenoemde research-groepen vinden twee niet met elkaar in overeenstemming zjjnde waraden voor de duur van de mitosefase van epidermale psoriasiscellen. De verschillen berusten op uiteenlopende warden die voor de mitotische indices voor en na toediening van de stathmokinetische stof zijn gevonden. Mogelijk speelt de niet-gelijke wijze van toedienen van de stathmokinetische stof een belangrijke rol hierbij. 


\subsubsection{INLEIDING EN METHODEN.}

Het percentage cellen in de $s$ fase van de celcyclus is een belangrijke parameter voor de mate van proliferatie van een celpopulatie. Bij voorkeur wordt voor het bestuderen van deze parameter gebrulk gemakt van thymidine, een obligatoire DNA-precursor, als dragersubstantie. Thymidine laat zich met tritium $\left(\mathbb{H}^{3}\right)$, zonodig in diverse concentraties (Heenen, 1971). of met radioactief koolstof $\left(\mathrm{C}^{\top 4}\right)$ markeren. Na inbouw in het DNA kan dit gelabeld thymidine worden angetoond door de dwarsgesneden huidcoupes te bedekken met een fotografische emulisie, deze enige tijd te exponeren aan het isotoop on vervolgens de coupes te ontwikkelen en op de gebruikelijke manier te kleuren (Joftes, 1963). Na intradermale injectie verschijnen de eerste gemerkte nuclei in de epjdermis na ongeveer 40 tot 60 minuten (Epstein \& Maibach, 1965). Gellabelde mitosefiguren verschijnen 12 ur na de injectie (Weinstein \& Van Scott, 1965). Na 2 celcycli kunnen nog gelabelde cellen worden gezien, een derde mitose reduceert de hoeveellheid gelabeld DNA tot onder de gevoeligheid van de autoradiografische film (Greulich, 1964).

Bij het onderzoek van de epidermis kan radioactief thymidine zowel in vitro (Hell \& Hodgson, 1966; Braum-Falco et al., 1967, Kaidby \& Kurban, 1971; Pullmann et al.,1974; Marks, 1978) als in wivo (Epstein \& Maibach, 1965; Welinstein, 1965; Weinstein \& Forst, 1968; Fry \& McMinn, 1966; Goodwin et al., 1974 ) worden toegepast. Gezien de lange halfwarade tijden van de isotopen $\left(\mathrm{H}^{3}: 12,3\right.$ jaar en $\mathrm{C}^{14}: 5556$ jaar) is toepassing bij mensen aan grenzen gebonden. De tijdsduur die verloopt tussen het afnemen van het monster en de beoordeling door de onderzoeker bedraagt bij het standaard autoradiografisch onderzoek 2-3 weken en is hiermee, samen met de arbeidsintensiviteit, het grootste nadeel van de methode. Bovendien kan door inbouw van een isotoop in de te onderzoeken cellen de proliferatieve activiteit van deze cellen worden beInvloed.

Met behulp van autoradiografle kan de celkinetiek worden bestudeerd door de labelling index (2.6.2.) te bepalen, door de tijd te registreren die de gemerkte cellen op hun weg door de epidermis voor de diverse celcompartimenten nodig hebben $(2.6 .3$.$) , door na een kortdurende toediening van het$ isotoop het aantal gelabelde mitosen grafisch uit te zetten als functie van de tijd (2.6.4.) of doox de populatie twee maal met een korte tussempauze gelabeld thymidne aan te bieden $(2.6 .5$.$) . Ook kan door continue toediening van het$ Isotoop $(2.6 .6$.$) of door de intensiteit van de labelling te$ meten $(2.6 .7$.$) inzicht worden verkregen lin celkinetische pa-$ rameters. 
De labelling lndex (L.I.) is het aantal gelabelde celien in een populatie gerelateerd aan het totale aantal cellen van die populatie. Het concept van de L.I. is gelijk aan dat van de M.I. met dien verstande dat de L.I. verscheidene malen groter is dan de M.I. omdat de duur van de DNA synthesefase verscheldene malen groter is dan de mitoseduur (Howard \& Pelc, 1953; Quastler sherman, 1959). De L.I. geeft de fractie van de celpopulatie in de $S$ fase an ten tijae van de toediening van het isotoop.

Door meerdere auteurs zijn de labelling indices van normale humane epidermis, van klinisch normale epidermis van personen met psoriasis en van psoriasislaesies bepaald. De gevonden resultaten zijn weergegeven in onderstaande tabel.

Tabe1 2.6.2.1.

\begin{tabular}{|c|c|c|c|}
\hline \multirow[t]{2}{*}{ Auteux } & \multicolumn{3}{|c|}{ Labelling index } \\
\hline & $\begin{array}{l}\text { Normale epi- } \\
\text { dermis }\end{array}$ & $\begin{array}{l}\text { Klinisch nor- } \\
\text { male epidermis } \\
\text { bij psoriasis }\end{array}$ & $\begin{array}{l}\text { Fsoriasis } \\
\text { laesie }\end{array}$ \\
\hline Kaku et a1.,1964 & 7 & - & - \\
\hline Epstein \& Maibach, 1965 & 4,9 & - & - \\
\hline He 11 \& Hodgson, 1966 & 0,9 & 2,7 & 4,1 \\
\hline $\begin{array}{l}\text { Christophers \& Schaum- } \\
\text { loffel, } 1967\end{array}$ & 3,3 & - & - \\
\hline Weinstein \& Forst, 1968 & 5,2 & - & 22,7 \\
\hline Kaidby \& Kurban, 1971 & 2,3 & 4,6 & - \\
\hline Steigleder et al. , 1973 & 2,0 & - & 8,8 \\
\hline Weinstein et a1. 1973 & 3,5 & - & - \\
\hline Heenen et aI. .1973 & 4,8 & - & - \\
\hline Pullmann et a1.,1974 & 2,4 & - & 13,6 \\
\hline Chopra \& Flaxman, 1974 & 10,5 & - & 12,0 \\
\hline Goodwin et al , 1974 & 0,9 & 1,8 & 11,0 \\
\hline Allegra De Panflis, & & & \\
\hline 1974 & 3,7 & - & - \\
\hline DufEdL1 et a1.,1976 & - & - & 10,3 \\
\hline Pullmann, 1978 & 2,8 & 5,7 & 10,6 \\
\hline
\end{tabular}

Tabel 2.6.2.1.: Overzicht van een antal in de literatuur opgegeven waarden voor de labelling indices van normale humane epidermis, klinisch normale epldermis bij psoriasis en van epldermiscellen uit een psoriasislaesie, ultgedrukt in procenten.

Vergelijking van deze indices wordt bemoeilijkt door het feit dat een aantal auteurs de populatie waaraan $z i j$ het aantal gelabelde cellen relateren niet expliciet omschrijven. 
Alle auteurs vinden dat de $\mathbb{L}$.I. bij psoriasis verhoogd is vergeleken met normale epidermis. Het sterk afwijkende percentage van weinstein \& Frost (1968) berust voor een deel op het toepassen van een correctiefactor door deze onderzoekers voor de korte relkwijdte van de b-partikels in de coupes. Het is echter omstreden of toepassing van deze factor, die ook door Iversen \& Evensen (1962) wordt onderschreven, juist is gezien de bevindingen van Gelfant (1961) die geen verschil in $L . I$. vinat in $2 \boldsymbol{\mu}$ en $7 \mu$ histologische coupes van dezelfde epidermis.

Ook het percentage cellen in de $s$ fase is in klinjsch normale huid verhoogd vergeleken met nomale epidermis.

Om met behulp van de L.I. celcyclustijden te berekenen is het noodzakelijk de duur van de $s$ fase te kennen. Deze tijd kan men bepalen met behulp van het percentage gelabelde mitosen als functie van de tijd (FLM curve, zle 2.6.4.) of door abbele labelling technieken (zie 2.6.5.).

Ook de M.I. is bij psoriasis verhoogd. Volgens Goodwin et al. (1973) is ex echter een duidelijke discrepantile tussen de toename van de M.I. en de L.I. bij psoriasis vergeleken met normale epidermis. Deze auteurs vinden dat de ratio van mitosen en DNA synthetiserende cellen groter is bij psoriasis dan die bij klinisch normale epidermis, die op zijn beurt weer groter is dan bij normale epidermis. Aangezien de formule M.I.:L.I. =Tm:Ts geldt kan deze stijging in ratio het gevolg zijn vam een langer worden van $\mathrm{Tm}$, zoals Fisher wells (1968) hebben gevonden, of van een kortere Ts, zoals Weinstein \&rost (1968) vonden. Een combinatie van belde tijasveranderingen is de derde mogelijkheid.

2.6.3. HET VOLGEN VAN GEMERKTE CELLEN OP HUN WEG DOOR DE DIVERSE COMPARTIMENTEN VAN DE EPIDERMIS.

Door het met korte tussenpauzen nemen van bilosieën na intradermale injectie van $\mathrm{H}^{3}$-thymidine is het mogelijk de progressie van gemerkte cellen in de epidermis te volgen. Aldus krijgt men inzicht in de tijd die verloopt alvorens een in de basale laag gemerkte cel de buitenste laag van het epitheel bereikt.

Uit de onderzoekingen van Epstein \&aibach (1965) blijkt dat 24 uur na intradermale injectie van $H^{3}$-thymidine in een normale humane epidermis de gemerkte nuclel juist boven de basale laag zijn gelocaliseerd. Na 7 dagen bevindt $z$ ich het merendeel van de gemerkte cellen in de middelste lagen van de epldermis, terwijl de eerste gemerkte cellen na 10-14 dagen in het stratum granulosum verschijnen. Deze laatste wararden stemmen overeen met de door Weinstein \&an Scott (1965) gevondem 13 dagen. Daarentegen vinden Kaku et al. (1964) een tija van 21 dagen alvorens de in de basale laag gemerkte cellen in de buitenste laag van de levende epidermis aankomen. Dit verschil in gevonden resultaten wordt mo- 
gelijk veroorzaakt door het kleine aantal monsters dat door de latste auteurs is onderzocht.

Deze methode is niet bruikbaar voor het bepalen van de turnovertijd van het stratum corneum omdat in deze laag normaliter geen celkernen meer aanwezig $z i j n$. In een psoriasis epidermis is het wel mogelijk de gemerkte parakeratotische cellen te volgen tot het moment warop zij de buitenste lagen van het stratum corneum bereiken.

Weinstein van scott (1965) vinden dat de passagetijd van een gemerkte cel door het levend epitheel van een psoriasisLaesie 48 uur bedraagt, terwijl de cellen na 4 dagen in de buitenste lagen van de hoornlaag aankomen.

Bovengenoemde resultaten zijn echter niet direct vergelijkbaar met de met andere methoden gevonden tijden omdat hier geen gemiddelde mar een minimum turnovertijd wordt bepaald.

2.6. 4. BEPALING VAN HET PERCENTAGE GELABELDE MITOSEN (FRACTION LABELLED MITOSIS, FLM).

Deze door Quastler \& Sherman (1959) ontwikkelde methode is een van de eerste en nog steeds een van de meest informatieve van ge isotopen methoden. Na toediening van een érnmalige dosis $\mathrm{H}^{3}$-thymidine wordt het percentage gelabelde mitosen met korte intervallen bepald. Bij de grafische voorstelling van het percentage gemerkte mitosen als functie van de tijd ontstaat een curve met twee hellingen, waaruit men de duur van de celcyclus en zijn deelfasen kan bepalen. Hierbij komt de duur van de $G_{2}$ fase overeen met de tijd tussen de injectie van het thymiaine en het verschijnen van de eerste gelabelde mitosen. De mitoseduur is het interval tussen het optreden van de eerste gemerkte mitosen en het tijdstip warop alle mitosen zijn gemerkt. De DNA synthesetijd wordt door het interval tussen de $50 \%$-punten van de stijgende en dalende helling van de FLM curve weergegeven. Een aantal auteurs geven de voorkeur aan de 37\%-punten lQuastler, 1963; Takahashi, 1966). De duur van de totale celcyclus tenslotte wordt bepaald ult het verschijnen van gemerkte mitosen van de tweede celgeneratie. Figuur 2.6.4.1. geeft een schematische voorstelling van deze methode.

Voorwarde voor het gelukken van deze methode is een niet te grote varlabiliteit van de deelfasen van de celcyclus tussen de cellen van het prolifererende systeem (Lennartz, 1967; Gerecke et a 1.,1970). De lage proliferatiegraad in normale humane epldermis makt het vrijwel onmogelijk met behulp van de FuM techniek directe metingen van basale celcyclustijden te verrichten (Wright, 1977). Deze problemen tracht men tegenwoordig te ondervangen door toepassing van bepaalde computerprogramma's (o.a. Gilbert, 1972). 
Figuar 2.6 .4 .1 .
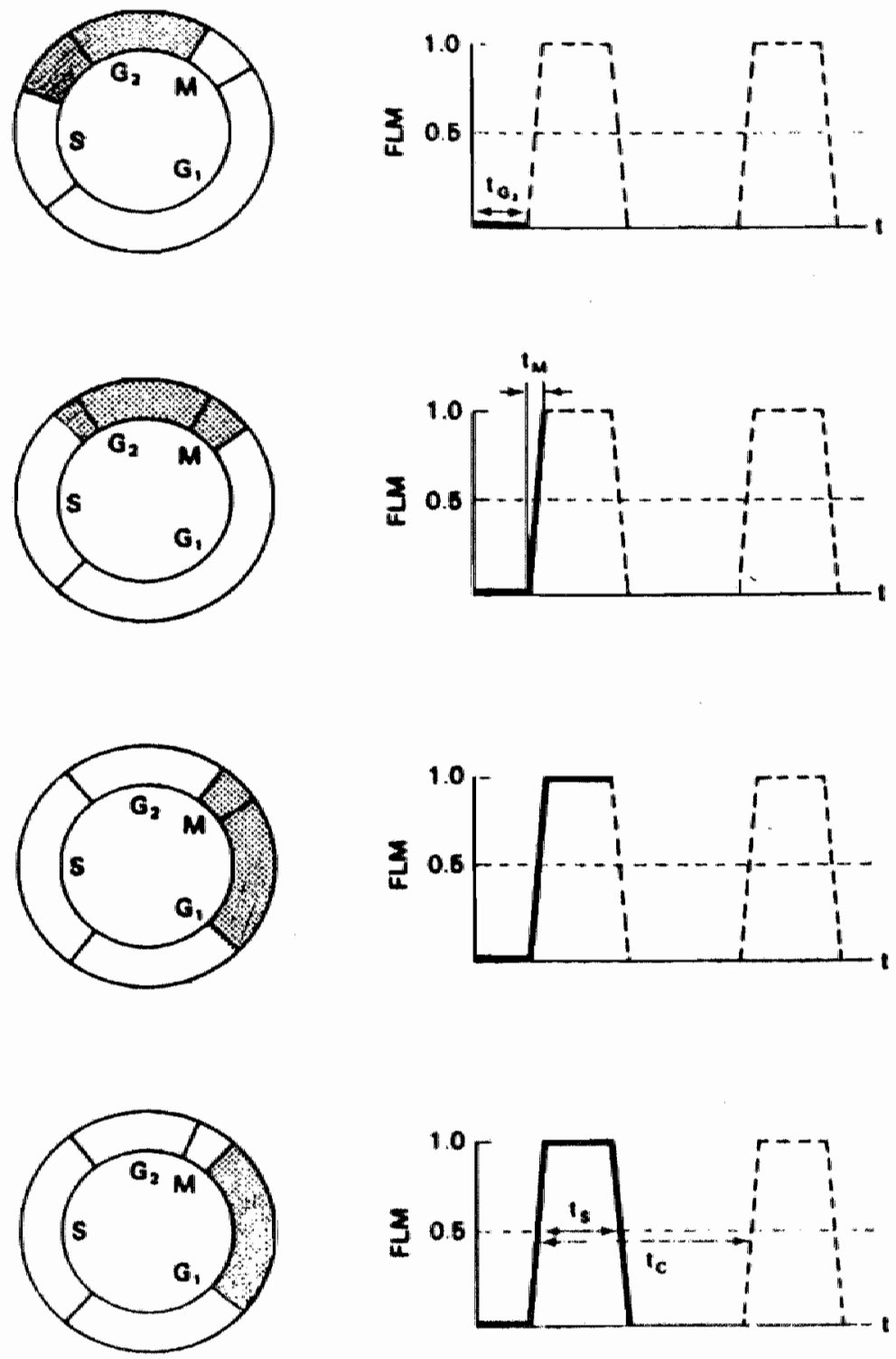

Figuur 2.6.4.1.: Schematische voorstelling van de FLM methode (Vrij naar Aherne (1977)). 
Ondat directe meting niet mogelijk was berekenden weinstein Frost $(1968,1969)$ met behulp van de $L . I$. en de Ts uit de FLM curve een totale celcyclustijd voor de normale humane basale epidermiscellen van 308 uur. In 1973 echter wordt deze tija door Weinstein Mc Cullough op 457 uur bepaald. Nadere detalls over deze latste warde ontbreken ondat de auteurs verwijzen naar hun "unpublished data". Hiermee in tegenspraak is de enige ons in de literatuur bekende, op deze wijze berekende celcyclustijd wan normale humane epidermis, die door Chopra \& Flaxman (1974) is bepaald op 59 uur. Dit laatste onderzoek heeft echter in vitro plaatsgevonden. De gevonden waarden $z i j n$ in tabel 2.6.4.2. samengevat.

Tabe $12 \cdot 6 \cdot 4 \cdot 2$.

\begin{tabular}{|c|c|c|c|c|c|c|}
\hline Auteur & Tc & $\mathrm{Tg}_{1}$ & $\mathrm{Ts}$ & $\mathrm{Tg}_{2}$ & $\operatorname{Tm}$ & I. I. \\
\hline $\begin{array}{l}\text { Weinstein \& Frost, } \\
1968 \\
\text { Welnstein \& Frost, } \\
1969 \\
\text { Weinstein \& Mc Cul- } \\
\text { lough, } 1973 \\
\text { Chopra \& Flaxman, } \\
1974\end{array}$ & $\begin{array}{r}163 \\
308 \\
457 \\
59\end{array}$ & $\begin{array}{l}146 \\
284\end{array}$ & $\begin{array}{l}8,5 \\
16\end{array}$ & $\begin{array}{l}6-8 \\
6-8\end{array}$ & 1,5 & $\begin{array}{l}5,2 \\
5,2\end{array}$ \\
\hline
\end{tabular}

Tabe1 2.6.4.2.: Overzicht van door diverse auteurs gevonden tijden in uren voor de celcyclus en zijn deelfasen van normale epidermis alsmede de gevonden labelling indices in procenten. $\mathbf{T c}=$ totale celcyclustijd, $\mathrm{Tg}_{4}=$ duur van de $G_{1}$ fase, $T s=$ duur van de $S$ fase, $T g_{2}=$ duur van de $G_{2}$ fase, $T m=$ duur van de mitosefase. L. I. = labelling index.

Ook over de celcyclustijd van een psoriasiscel bestaan in de literatuur tegenstrijdige opvattingen. Enerzijas zijn er de opvattingen van weinstein en medewerkers (1968-1971) dat deze tijd 37,5 uur bedraagt. Goodwin et al. (1974) vinden daarentegen een totale celcyclustijd bij psoriasis van 91 uur. Chopra \& Flaxman (1974) en Duffill et al. (1976) vinden intermediaire warden. De bevindingen zijn samengevat in tabel 2.6 .4 .3 . 
Weinstein \& Forst, 1968

Goodwin et al.,

1974

Chopra \& Flaxman,

1974

Duffill et al.

1976

$\begin{array}{lllccc}37,5 & 24 & 8,5 & 4 & 0,3 & 22,7 \\ 91 & 73,5 & 9,8 & 7,2 & 0,5 & 11,0 \\ 53,5 & 38,9 & 6,5 & 7 & 1,1 & 12,0 \\ 56 & \pm 43 & 7,7 & \pm 5,6 & - & 10,3\end{array}$

Tabe1 2.6.4.3.: Overzicht van door diverse auteurs berekende tijden in uren voor de totale celcyclus en zijn deelfasen, berekend met behulp van FIM curves, en de gevonden labeling indices (L.I.) in procenten van de prolifererende celpopulatie uit een psoriasislaesie. Mcis totale celcyclustijd, $\mathbb{T g}_{1}=$ duur van de $\mathrm{G}_{1}$ fase, $\mathrm{Ts}=$ duur van de $\mathrm{S}$ iase, $\mathrm{Tg} \mathrm{g}_{2}=$ duur van de $G_{2}$ fase, $T m=$ duur van de mitosefase.

Alle auteurs hebben de totale celcyclustija berekend uit de formule $\mathrm{Ns}: \mathbb{T} s=$ Ntot:Ttot. De al dan niet met behulp van computerprogramma's gevonden waarden voor Ts zijn niet bepalend voor de gevonden verschillen in celcyclustija. Deze berusten op de uiteenlopende labelling indices. Het toepassen van een correctiefactor bij de bepaling van de L.I. door Weinstein en medewerkers is reeds elders besproken.

De door Weinstein vermelde celcyclustijd blj psorlasis vormde de rationele achtergrond voor de behandeling van psoriasis met cytostatica zoals methotrexaat (Weinstein, 1971; Weinstein \& Mc Cullough, 1976). Jarenlang zijn deze celcyculstijaen en de hierop gebaseerde therapeutische reglmes offlicieel door de American Academy of Dermatology gesteund en onderschreven (Weinstein, 1973) en heeft het systemisch toedienen van methotrexaat bij de behandeling van psoriasis. de goedkeuring van de F.D.A. (Roenigk et a1.,1973; Weinstein et a.1.,1981). 
De 5 fase dur alsmede de celcyclustijd van de proliferatieve celpopulatie kan worden bepaald door de populatie met een korte tussenpauze tweemal kortdurend gelabelde thymidine aan te bieden (H1Ischer \& Murer, 1962; Wimbler \& Quastler, 1963). De op de verschillende tijdstippen gemerkte cellen kunnen worden onderscheiden door toediening van verschillend hoge doses $\mathrm{H}^{3}$-thymidine of, bij voorkeur, van $\mathrm{H}^{3}$ en $\mathrm{C}^{14}$-thymidine. Deze beide isotopen zenden beta stralen van verschillende energile en relkwijdte uit $\|_{H^{3}}: E_{\max }=18 \mathrm{KeV}, \overline{\mathrm{E}}=5 \mathrm{KeV}$, reikwijdte in water $7 \mu ; C^{4}: E_{\max }=156 \mathrm{KeV}, \overline{E^{\prime}}=49 \mathrm{KeV}$, reikwijate in water $240 \mathrm{\mu l}$ ). Beide stralingen kunnen door toepassing van geschikte foto-emulsies worden gedifferentieerd. In de autoradiografische preparaten wordt de fractie van de verschillend gelabelde nuclei van de gelabelde cellen in de basale laag van de epidermis bepald. De duur van de $s$ fase wordt berekend uit de verhouding van influx en efflux van de gelabelde cellen in en uit de $\mathrm{S}$ fase. De totale celcyclustijd wordt berekend uit de duur van de $S$ fase en de L.I.. Figuur 2.6.5.1. geeft een schematische voorstelling van de methode.

Figuur $2 \cdot 6 \cdot 5 \cdot 1$.

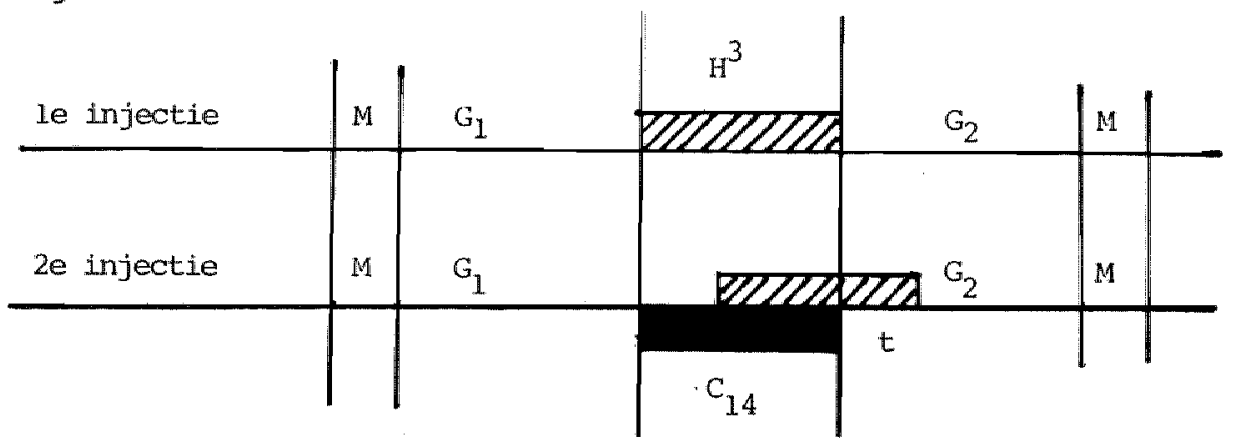

Figuur 2.6.5.1.: (Vrij naar Pullmann (1978)). Bepaling van de duur van de $S$ fase met behulp van de DLM. Met een interval van 1 uur (t) wordt de populatie kortdurend met $\mathrm{H}^{3}$ en vervolgens met $C^{14}$ gemerkt thymidine aangeboden. Tijdens de eerste incubatie worden alle cellen, die $z j$ ch in de $S$ fase bevinden met $H^{3}$-thymidine gemerkt. Na de tweede incubatie, met $c^{14}$-thymidine, blijven de cellen die in het interval t de $s$ fase hebben verlaten lefflux) alleen met $\mathrm{H}^{3}$ gemerkt, terwijl de cellen, die in dit tijdsbestek de $s$ fase zijn binnengekomen (infIux) alleen met c14 worden gemerkt. Met beide isotopen worden die cellen gemerkt, die tijdens de procedure in de $S$ fase blijven. Uit de verhouding van alle $c^{14}$ gelabelde cellen lalleen $c^{14}$; resp. $\mathrm{C}^{14}+\mathrm{H}^{3}$ ) en het aantal cellen dat alleen met $\mathrm{H}^{3}$ is gemerkt, kan de duur van de $s$ fase worden berekend. 
Met bovengenoemde methode is door Heenen Galand (1971) een $T$ san 10 unr en een totale celcyclustijd van de proIifererende celpopulatie in een normale humane epidermis van 213 uur berekend. Deze warden stemun in meerdere of mindere mate overeen met de met dezelfde methode verkregen gegevens van Christophers \& Schaumlöffel (1967), Heenen et a1. (1973), Steigleder et al. (1973), Allegra \& De Panfilis (1974), Pullmann et al. (1974) en Pullmann (1978) voor normale humane epidermis. De diverse celkinetische parameters zijn in tabe1 2.6.5.1. samengevat.

Tabe1 2.6.5.1.

Auteur

Christophers \& Schaumloffel 1,1967

Heenen \& Galand, 1971

Heenen et al.,1973

Steigleder et al.,1973

Pullmann et a1.,1974

Allegra \& De Panfilis, 1974

Pullmann, 1978
$\mathrm{TS}$

$\begin{array}{rr}5,6 & 154 \\ 10,0 & 213 \\ 10,3 & 184 \\ 6,6 & 312 \\ 6,6 & 282 \\ 7,5 & 206 \\ 7,2 . & 296\end{array}$

L. I.

Tabel 2.6.5.1.: Overzicht van met behulp van de dubbele labelling methode gevonden warden voor de duur van de DNA synthesefase in uren en de hieruit met behulp van de gevonden labelling indices berekende totale celcyclustijden in uren van de proliferatieve celpopulatie in normale epidermis. De labelling indices (L.I.) zijn weergegeven in procenten. Ts= duur $s$ fase, $T C=$ totale celcyclustijd.

ook bij onderzoekingen met de dubbele labelling methode wordt bij psoriasis een kortere totale celcyclustija gevonden dan bij normale epidermis. (Stelgleder et a $1 ., 1973$; Pullmann et a1.,1974; Pullmann, 1978). Tevens vinden deze onderzoekers dat de dur van de $S$ fase bij psoriasis significant verlengd $1 \mathrm{~s}$. Tabe $12 \cdot 6 \cdot 5.2$. geeft een samenvatting van de gevonden gegevens. 
Tabe 12.6 .5 .2 .

Auteur Ns TC T.I.

Steigleder et al. 1973

Pullmann et a1., 1974

Pullmann, 1978

$\begin{array}{rrr}14,0 & 173 & 8,8 \\ 14,4 & 114 & 13,6 \\ 1) 13,6 & 146 & 10,6 \\ 2119,9 & 202 & 11,1\end{array}$

8,8

13,6

11,1

Tabe1 2.6.5.2.: Overzicht van met de dubbele labelling methode gevonden warden voor de duur van de $S$ fase in uren en de hieruit met behulp van de gewonden labelling indices berekende totale celcyclustijden in uren van psoriasiscellen. TS $=$ duur $S$ fase, $T c=$ totale celcyclustijd, L. I. = labeliling index in procenten, $11=$ volontwikkelde laesie, $21=$ beginnende psoriasislaesie.

\subsubsection{CONTINUE LABELLING METHODE.}

Bij de continue labelling methode wordt de te onderzoeken celpopulatie blootgesteld aan een continue toediening van het label gedurende een langere periode. Dit kan in vivo worden berelkt door, ofwel herhaalde injecties met intervallen korter dan de 5 faseduur, zodat geen cel die de $s$ fase passeert aan de labelling ontsnapt, of door continue infusie. Behalve het feit dat continue toediening van een isotoop bij mensen nlet gewenst is, stelt deze methode de proefdieren ook bloot aan een ongewenste fysiologische stress. Het beste kan deze methode in vitro worden toegepast.

De L.I. als functie van de tijd wordt bepaald. Het tijdsinterval dat verloopt tussen toevoegen van het isotoop en het tijdstip warop de fractie van gelabelde cellen een plateau bereiken is gelijk an de celcyclustijd minus de tijdsduur van de $S$ fase. In theorie kan de tijdspanne $\mathrm{Tg}_{2}$ * Tn + $\mathrm{TI}_{1}$ nader worden bepaald in zijn componenten. Het tijdsinterval ${ }^{\mathrm{TM}} \mathrm{g}_{2}$ + Im is de tijd die nodig is om alle mitosen te merken. vit het verschil kan Ig/ worden bepaald. De durir van de S fase kan op meerdere manieren met behulp van de continue labelling methode worden berekend. De mate van toename van het aantal gelabelde cellen in de tijd, analoog aan de berekeningswijze blj stathmokinetische experimenten, is het meest rechtstreeks. Elegant is de combinatie van stathmokinesis en continue labelling zoals beschreven door puck \& steffen

(1963). Ook deze techniek is echter slechts geschikt voor in vitro onderzoek.

Een andere toepassing van de continue labeling methode vormt de berekenlng van de fractie cellen in de prolifererende populatie die de celcyclus niet doorlopen, maar deze hebben verlaten om in een rustfase te verkeren waaruit zij weer in de celcyclus kunnen terugkeren $\left(G_{0}\right.$ cellen). Figuur 2.6.6.1. geeft een schematische voorstelling van de methode. 
ons zijn in de literatuur geen studies op dermatologisch gebied bekend warbij celcyclustijden volgens deze methode worden berekend. Toepassing van deze methode bij het celkinetisch onderzoek van de epidermis stuit in vivo op ethische bezwaren, terwijl de voor de in vitro toepassing noodzakelijke kweektechnieken om een volwassen humane epidermis enkele dagen levend te houden nog onvoldoende zijn. Bovendien ontbreken in vitro een aantal mechanismen ter regulatie van de groei.

De groeifractie is het percentage cellen van de proliferende basale en suprabasale celpopulatie dat de celcyclus daadwerkelijk doorloopt. Deze groeifractie is in vitro voor normale epidermis door Chopra \& Flaxman (1974) op $66 \%$ na 3 dagen gesteld. Bij psoriasis vinden deze auteurs een groeifractie van 748 na 3 dagen in vitro. Weinstein (1971) daarentegen vindt in vivo bij psoriasis een groeifractie van vrijwel $100 \%$. Voor normale humane epidermis in vivo is de groeifractie miet bekend.

Figuur $2 \cdot 6 \cdot 6 \cdot 1$

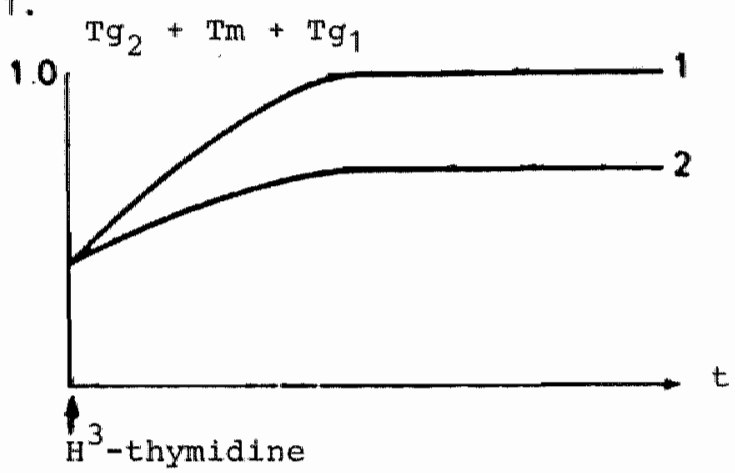

Figuur 2.6.6.1.: Continue labeling methode: Bij het begin van het experiment zullen de cellen in de $S$ fase het isotoop opnemen. In de tijd die hierop volgt zullen alle cellen die de $s$ fase binnenkomen eveneens worden gelabeld. De labeling indices zullen derhalve in de tijd toenemen. Wanneer alle prolifererende cellen zijn gelabeld hebben de L.I. een plateau bereikt. De tijd tussen het moment van toedienen van het 1 sotoop en het bereiken van het plateau is gelijk aan $\mathrm{Tg}_{2}$ * Tm + Tg1. Indien alle cellen in de populatie prolifereren stijgen de labelling indices in de tijd volgens lijn 1. Indien slechts een deel van de populatie aan de proliferatie deelneemt geschiedt de toename volgens lijn 2. Op deze wijze kan de groelfractie en derhalve het percentage $\mathrm{G}_{\mathrm{O}}$ cellen van de betrokken populatie worden bepaald. Figuur overgenomen uit Aherne (1977). 
Bif alle tot nu toe beschreven autoradiografische technieken wordt het percentage gemerkte interfase cellen of gemerkte mitosen geteld. Onder bepaalde omstandigheden kan informatle worden verkregen door de intensiteit wan de labelling te bepalen en na te gaan hoe deze intensiteit zich in het verloop van de tijd gedragt. De intensiteit van de labelling wordt bepald door het aantal korrels boven de gemerkte nuclel te tellen. Uit de halvering van het gemiddelde aantal korrels per nucleus kunnen diverse tijden van de celcycluscomponenten worden berekend (Kilimann et al. . 1963; Clarkson et al., 1967). Deze techniek is, in het bijzonder wanneex ex een signiflcante overgang van proliferatieve naar non-proliferatieve cellen bestaat, aammexkelijk minder nauwkeurig dan b.v. FlM curves (Aherne et a1.,1977).

Gegevens over celkinetisch onderzoek van de humane epidermis, berekend met behulp van deze methode; hebben wij in de ons bekende literatuur niet gevonden.

In vereenvoudigde vorm kan de methode wel informatile geven over de relatieve celcyclustijden omdat het aantal korrels per nucleus een mat vormt voor de synthesesnelheid per tijdseenheid. Op deze wijze hebben Born \& Kalkoff (1969) gevonden dat het gemiddelde aantal korrels per gelabelde cel bij psoriasis met de helft is gereduceerd vergeleken met normale epidermis, terwijl de $L$. I. niet was verandera. Deze auteurs concluderen hieruit dat de duur van de synthese fase met een factor 2 is verlengd. In klinisch normale huid van personen met psoriasis vinden $z i j$ eveneens een kleiner aantal korrels per gelabelde cel dan bij normale controle persomen (Born \& Kalkoff, 1969).

2. 7. SCINTILLATIE TELLING.

Het is mogelijk de opname van an thymidine gebonden isotopen op een andere wijze dan met autoradiografie te meten. Door de in oplossing gebrachte, te onderzoeken celpopulatie te mengen met een scint1llatie vloeistof kan de hoeveelheid radioactiviteit in het monster worden bepaald, omdat de moleculen van het fluorescerende bestanddeel van de scintillatie vloeistof, wanneer zij getroffen worden door een tritium of $\mathrm{C}^{14}$ beta partlke1, emissielicht uitzenden (Aherne et $a 1 ., 1977$ ). Deze methode geeft de gemiddelde incorporatie per cel. Het voordeel van de methode is de snelheid waarmee de resultaten worden verkregen en het grote aantal cellen dat kan worcen gemeten. Het verlies van het $z$ icht op de aparte cellen kan een nadeel zijn. Met deze methode is het niet mogelijk onderscheid te maken of een verandering in radioactiviteit het gevolg is van een verandering in het antal cellen dat gemerkt thymidine opneemt of van een verandering in de hoeveelheld thymidine die door elke cel wordt opgenomen.

Toepassing van deze techniek bij het onderzoek naar de kinetiek van de humane epidermis lijkt ons niet zinvol. 
De kwantitatieve cytospectrophotometrie is ontwikkeld door Casperson (1936) uitgaande van de wet van Lambert-Beer. warbij de absorptie van monochromatisch licht van een oplossing in een cuvette evenredig ls met de concentratie van de chromophoor. De wet van Lambert-Beer toegepast in de cytochemie geeft an dat de totale absorptie van een object onder het microscoop evenredig is met de totale hoeveelheld chromophoor in at object. Hiervan afgeleid is de cytophotometrie waarbij een indirecte meting van de celcomponenten na kwantitatieve kleuring plaats vindt. Door gebruik te maken van fluorochromen ontstond de cytofluorophotometrle. Bij het onderzoek naar de celkinetiek bepaalt men als intracellulaire component het gehalte aan DNA. De cytophotometrie is onder te verdelen in de statische cytophotometrie en de flowcytometrie.

2.8.1. STATISCHE CYTOPHOTOMETRIE.

Bij de statische cytophotometrie wordt de te onderzoeken celpopulatie op een objectglas gebracht en wordt het DNA van de celkernen kwantitatief gekleurd. De absorptiewaarden van de Feulgen gekleurde cellen worden gemeten en vervolgens ingedeeld in DNA klassen. Door het aantal cellen dat binnen een bepald DNA gebied wordt gevonden uit te zetten tegen de DNA warden wordt een histogram verkregen. Aldus kan het percentage cellen in elke fase van de celcyclus worden bepaald. De relatieve duur van de fasen kan uit de zogemaakte DNA distributie worden bepaald. Door de duur van een van de fasen onafhankelijk te meten, kunnen absolute celcyclustijden worden berekend.

De absorptiewet van Lambert-Beer geldt echter niet voor niet homogeen gekleurde objecten zoals Feulgen gekleurde celkernen. In dat geval worden geen absorptiewaarden maar transmissiewaarden gemeten, waardoor een distributiefout optreedt (van Vloten, 1974). Aanvankelijk werd gemeten met een cytophotometer, gebaseerd op het twee-golflengten principe, ontwikkeld door ornstein (1952) en Patau (1952) en vervolmakt door Mendelsohn (1958), van Duijn (1966) en Cohn van Duijn (1967), waarbij de distrubutiefout sterk wordt verkleind. Tegenwoordig wordt deze fout zo veel mogelijk geelimineerd door het meetveld zo klein te kiezen, dat kan worden aangenomen dat de kleurstof hierin homogeen is verdeeld (Goldstein, 1970,1971; van Vloten, 1974). De verdere nadelen zijn, naast de inhomogenitelt van het veld en de verschillen in achtergrondabsorptie, de arbeldsintensiviteit en de geringe statistische betrouwbaarheid van de methode. Bovendien veroorzaken beschadigde kernen te lage DNA waarden (Würthner et al, 1972). Om deze redenen is getracht het te onderzoeken weefsel te scheiden in aparte cellen of intacte nuclei. Als regel gebeurt dit door toediening van diverse enzymen gecombineerd met mechanjsche homagenisatie (Rinaldi,1958; Giovanella Heidelberger, 1969; Alavaikko,1971; Schumann et al.,1971). Elke enzyma- 
tische of chemische methode heeft echter in meerdere of mindere mate decompositie van de te meten nucleinezuren tot gevolg (Filkuka et al.,1968; Franke et al.,1973; Haag et a1.,1975).

De statische cytophotometrie is bij het onderzoek naar de celkinetiek van de epidermis toegepast door coupes te snijden van het huidbiopt (Grove et al.,1976) en door uitstrijkpreparaten te maken van een epidermale celsuspensie (Haag et al...1975). Grove et al. (1976) vinden bij psoriasis een sterke toename van het aantal cellen in de $S$ fase vergeleken met de normale epidermis, terwijl dit percentage bij kilnisch normale huid van personen met psoriasis eveneens hoger, zij het in geringe mate, ligt dan bij normale epldermis. Haag et al. $(1975)$ bestudeerden het DNA gehalte in gersoleerde nuclel van humane epidermis cellen. zij geven echter geen gedetallieerde analyse van de gevonden histogrammen. Beide metingen hebben betrekking op een relatief gering antal cellen.

\subsubsection{FLOWCYTOMETRIE.}

Daar de statische cytometrie is gelimiteerd door het relatief geringe antal cellen dat in een bepaalde tijdsduur kan worden onderzocht is in de jaren zestig een nieuwe methode ontwikkeld. Researchgroepen in de International Business Machines-Watson (Kamentsky et al.,1965), de Los Alamos Scientific Laboratory Van Dilla et al.,1967, 1969; Mullaney et al. "1969), Stanford University (Hulett et al., 1969), Universität Münster (Dittrich \& Göhde, 1969) en de Universitat Freiburg (Sprenger et al.,1971) ontwikkelden de flowcytometrie warbij de te meten cellen in een continue stroom het meetweld passeren. Ofschoon door bovengenoemde auteurs een scala aan diverse instrumentele ontwerpen werd gebruikt gaan ze alle uit van hetzelfde principe; de afzondexlijke cellen stromen achter elkaar door een bundel. excitatie licht. Wanneer de cellen deze lichtstraal passeren, vinden fotometrische metingen van fluorescentie, absorptie of lichtverstrooilng of van verschillende combinaties van deze parameters plaats.

Flowcytometrie is het meest toegepast bij de fluorescentie meting van het cellulaire DNA gehalte. Voor deze kwantitatieve metling van de hoeveelheid DNA moeten de celkernen gekleurd worden met een fluorescerende kleurstof die zich speciflek en kwantitatief aan DNA bindt. Momenteel zijn er meerdere van deze fluorochromen beschikbaar.

Gebaseerd op de Feulgen procedure zijn de fluorochromen Auramine O (Trujillo van Dilla,1972) en Acriflavine (Kasten, 1959; Kraemer et al.,1972) alsmede de kleurstof Flavophosphine $\mathrm{N}$ (Cxissman et al.,1975). RNA levert geen bijdrage aan de kileuring omdat het snel wordt verwijderd uit de celien tijaens de zure hydrolyse (Ely \& Ross, 1949).

Door Le Pecq \& Paletti (1967) is ethidium bromide geintroduceerd, een fluorochroom dat selectieve en kwantitatieve chelatievorming aangaat met de "double stranded" gebieden 
van nucleinezuren. Na behandeling van de cellen met RNA-ase is ethidium bromide geschikt als kwantitatieve kleurstof voor DNA (Dittrich \& Göhde, 1969). Analoog aan ethidium bromide is propidium jodide (Hudson et al.,1969).

Het voor DNA zeer specifieke mithramycine is geintroduceerd door Crissman \& Tobey (1974). Mithramycine geeft geen significante interactie met RNA (Ward et al., 1965).

Flowcytometrie wordt toegepast bij het onderzoek naar de celkinetiek van prolifererende systemen, de tumordiagnostiek, de tumorresearch, de evaluatie van therapieèn, chromosoomanalyse, porphyrine diagnostiek en op het terrein van de immunologie, enzymologie, histochemie en moleculaire biologie (Impulscytophotometrie, 1975; Pulsecytophotometry, part 1, 1975 ; part 2,1976; part 3,1978 ; part 4,1979; part 5,1980; part 6,1982$)$. Bij het onderzoek naar de kinetische aspecten van de normale en pathologisch veranderde humane epldermis is de flowcytometrile voor het eerst door Bauer De Grood (11975) toegepast.

Het belangrijkste voordeel van de flowcytometrische methode is thet grote aantal cellen dat geteld wordt waardoor de statistische betrouwbaarheid sterk verbetert. De tijdwinst en de objectiviteit zijn verdere voordelen. De belangrijkste nadelen van de methode $z i j n$ het verlies van directe observatie van de cellen en het verlies van celverband.

De laatste jaren heeft het onderzoek met behulp van de flowcytometer een grote vlucht genomen. De instrumentele ontwikkelingen waren ultgebreid en veelzijdig, hetgeen heeft geleid tot een grote uitbreiding van de toepassingen van deze techniek. De florissante groei van de flowcytometrie wordt op fraale wijze geillustreerd door het grote aantal internationale symposia gewijd aan deze techniek en zijn toepassingen.

2.9. SAMENVATTING EN DISCUSSIE.

De diverse methoden om celcyclustijden en turnovertijden van het levend epitheel en de totale epidermis te bepalen geven sterk uiteenlopende resultaten.

De door de diverse auteurs gevonden mitotische indices (2. 5.1.) lopen zo sterk uiteen, terwijl bovendien de geschatte duur van de mitosefase sterk subjectlef $1 \mathrm{~s}$, dat hierult geen betrouwbare turnovertijden en celcyclustijden kunnen worden berekend. Well staat vast dat de M.I. bij psorlasis sterk verhoogd is vergeleken met de normale epidermis.

Berekening van de mitoseduur uit de toename van de M.I. na stathmokinesis (2.5.2.) levert ook tegenstrijdige gegevens op. Fisher \& Welis (1968) vinden een verlenging van de Tm, terwijl Duffill et al. (1976) een kortere Tm vinden bij psoriasis vergeleken met normale epldermis. 0ok onderzoekingen met behulp van andere technieken door diverse auteurs brengen hiexin geen verbetering (tabel" 2.9.1.). 
Tabe1 2.9 .1

\begin{tabular}{|c|c|c|c|}
\hline Auteur & Methode & $\mathbb{N}$ & $\mathrm{PS}$ \\
\hline Fisher we11s, 1968 & $\begin{array}{l}\text { M.I. + stathmo- } \\
\text { kinesis }\end{array}$ & 90 & 240 \\
\hline Duffi11 et al, 1976 & $\begin{array}{l}\text { M.I. + stathmo- } \\
\text { kinesis }\end{array}$ & - & 37 \\
\hline & FLM. & \pm 60 & 38 \\
\hline $\begin{array}{l}\text { Welinstein Erost, } \\
1968 \\
\text { Goodwin et al. } 1974 \\
\text { Pullmann, } 1978\end{array}$ & $\begin{array}{l}\text { FLM. } \\
\text { ELM. } \\
\text { DL. }\end{array}$ & $\begin{array}{l}60 \\
60 \\
72\end{array}$ & $\begin{array}{r}18 \\
30 \\
210\end{array}$ \\
\hline
\end{tabular}

Tabe1 2.9.1.: Overzicht van door diverse auteurs gevonden tijden voor de duur van de mitosefase in minuten bij normale $(=N)$ en psoriasis epidermis $(=P S)$. M.I. = mitotische index; FLM.= fraction labelled mitosis curve; $\mathrm{DL}=$ = dubbele labelling methode.

Meer overeenstemming bestaat er over de turnovertijd van het stratum corneum (tabel 2.9.2.). Berekening van de celcyclustijd van de proliferatieve celpopulatie uit de transittijd van het stratum corneum geeft warden die niet tegenstrijaig zijn met de celcyclustijden berekend met autoradiografische methoden. Bij psoriasis is deze tijd sterk verkort.

Tabe1 2.9 .2 .

\begin{tabular}{|c|c|c|c|}
\hline Auteur & Methode & $\mathbf{N}$ & PS \\
\hline $\begin{array}{l}\text { Rothberg et al.,1961 } \\
\text { Frost et al.,1966 } \\
\text { Baker \& KI gman, } 1967 \\
\text { Jansen et al. } 1974 \\
\text { Weinstein \& Van Scott, }\end{array}$ & $\begin{array}{l}\mathrm{C}^{14}-\mathrm{glycine} \\
\mathrm{H}^{3}-\mathrm{glycine} \\
\mathrm{T} \cdot \mathrm{C} \cdot \mathrm{S} \cdot \mathrm{A} . \\
\text { Dansylchloride } \\
\mathrm{H}^{3} \text {-thymidine }\end{array}$ & $\begin{array}{l}13-14 \\
12-14 \\
12-15 \\
11-18 \\
-\end{array}$ & $\begin{array}{l}3-4 \\
- \\
- \\
4\end{array}$ \\
\hline
\end{tabular}

Tabel. 2.9.2.: Overzicht van door diverse auteurs gevonden turnovertijden van het stratum corneum in dagen voor normale $(=\mathrm{N})$ en psoriasis (=PS) epldermis.

Met behulp van radioactieve aminozuren is de turnovertijd van de totale epidermis bepaald op 28 dagen (Rothberg et a1. 1961). Het is echter omstreden of het door deze auteurs 
gebruikte aminozuur in de basale laag van de epidermis wordt ingebouwd.

De resultaten, verkregen met de histogeometrische benaderingswijze van Van scott \& Ekel. (1963) stemnen slechts in die $z$ in overeen met de met andere methoden verkregen resultaten, dat bij psoriasis de turnovertijd is versneld.

Het vervolgen van met radiaactief thymidine gemerkte cellen op hun weg door de diverse strata van de levende epidermis geeft transittijden voor normale epidermis van 13-18 dagen (2.6.3.). Met deze methode is het niet mogelijk celcyclustijden te berekenen.

De meest informatieve van de autoradiografische methoden is de FLM. methode en de dubbele labeliling methode. In onderstaande tabelien 2.9.3. (normale epidermis) en 2.9.4. (psoriasis) worden de diverse parameters samengevat.

Tabe1 2.9.3.

\begin{tabular}{|c|c|c|c|c|}
\hline Auteur & Methode & L. I. & Ts & $\mathrm{TC}$ \\
\hline $\begin{array}{l}\text { Christophers \& Schaum- } \\
\text { löffel,1967 }\end{array}$ & DL. & 3,3 & 5,6 & $142-166$ \\
\hline $\begin{array}{l}\text { Heenen et al. } 1973 \\
\text { Stelgleder et al.,1973 } \\
\text { Weinstein et al.,1973 } \\
\text { Pullmann et al.,1974 } \\
\text { Allegra \& De Panfilis, }\end{array}$ & $\begin{array}{l}\text { DL. } \\
\text { DL. } \\
\text { FLM. } \\
\text { DL. }\end{array}$ & $\begin{array}{l}5,8 \\
2,0 \\
3,5 \\
2,4\end{array}$ & $\begin{array}{r}10,3 \\
6,6 \\
16,0 \\
6,6\end{array}$ & $\begin{array}{l}184 \\
312 \\
457 \\
282\end{array}$ \\
\hline $\begin{array}{l}\text { Allegra \& De Panrliss, } \\
1974 \\
\text { Chopra \& Flaxman, } 1974 \\
\text { pullmann, } 1978\end{array}$ & $\begin{array}{l}\text { DL. } \\
\text { FLM. } \\
\text { DL. }\end{array}$ & $\begin{array}{r}3,7 \\
10,5 \\
2,8\end{array}$ & $\begin{array}{r}7,5 \\
11,5 \\
7,2\end{array}$ & $\begin{array}{r}206 \\
59 \\
296\end{array}$ \\
\hline
\end{tabular}

Tabe1 2.9.3.: Overzicht van door diverse auteurs met behulp van autoradiografische methoden gevonden waarden voor labelling index (L.I.) in procenten, duur van de synthesefase (TS) en de totale celcyclustijd (Tc) in uren voor normale epidermis. DL. = dubbele labelling me thode; FLM. = fraction labelled mitosis curve. 
Weinstein et al. 1968

stelgleder et al., 1973

Chopra Flaxman, 1974

Goodwin et al., 1974

Duffill et a1.,1976

Pulimann, 1978
ELM.

DL.

FLM.

ETM.

FLM.

DL.
22,7

8,8

12,0

11,0

10,3

10,6
8,5

14,0

6,5

10,0

7,7

13,6
37,5

173

53,5

91

56

146

Tabe1 2.9.4.: Overzicht van diverse celkinetische parameters voor een psoriasis epidermis bepaald met autoradiografische methoden. L.I. =labelling index in procenten; ELM. = fraction labelled mitosis curve; $\mathbb{D L}$. = dubbele labelling methode: $\mathrm{Ts}=$ duur van de $\mathrm{S}$ fase in uren; $\mathrm{TC}=$ totale celcyclustija in uren.

Alle auteurs zijn het erover eens dat de labeling index bij psoriasis is verhoogd, zij het met grote graduele verschillen, vergeleken met normale epidermis. De Ts is volgens Weinstein en Chopra \& Faxman bij psoriasis verkort, volgens Goodwin niet veranderd en volgens steigleder en pullmarn verlengd t.o.v. normale epidermis. Ook de onderzoekingen van Born \& Kalkoff (1969) met behulp van het tellen van korrels boven de gemerkte cellen (2.6.7.) wijzen in de richting van een verlengde Ts.

Over een verkorting van de totale celcyclustijd bil psoriasis, zij het ook weer in wisselende mate, zijn alle auteurs het eens.

De groelfractie in vivo van een normale humane epidermis is niet bekend. Bij psoriasis worden in de literatuur uiteenlopende warden voor de groelfractie opgegeven.

De continue labelling methode, het meten van de intensitelt van de labelling alsmede de scintillatie teling methode zijn ons inziens bij het onderzoek naar de diverse cellkinetische parameters van de humane epidermis niet zinvol.

De statische cytometrische methode is op het gebied van het onderzoek naar de celkinetiek van normale en pathologisch veranderde humane epidermis sporadisch toegepast. De in de literatuur vermelde gegevens hebben slechts een voorlopig karakter (Haag et al.,1975; Grove et al.,1976). 
De flowcytometrile biedt met het oog op de veel grotere statische betrouwbaarheid, de objectiviteit, de gunstige arbeidsintensiviteit en de snelheid waarmee de gegevens worden verkregen grote perspectieven. Bovendien is de flowcytometrie ons inziens de enige mogelijkheid om therapieeffecten op celkinetisch niveau op de voet te volgen. 
2.10. REFERENTIES.

Abercrombie, M. : Estimation of nuclear population from microtome sections. Anat. Rec, $94: 239-247,1946$.

Aherne, W., Camplejohn, R. Mright, N.: An introduction to cell population kinetics, Edward Arnold 1td, London, 1977.

Alavalkko, M.: Selective separation of mouse epldermal cells and cytophotometric evaluation of their nuclear DNA. Acta Path. Microbiol. Scand.,226:9-76,1971.

Allegra, $F$. \& De Panfilis, G.: An in vivo method of studying the kinetics of cell proliferation in normal human epidermis. Acta Dermatovener., 54:87-90,1974.

Baker, H. Blair, C.: Cell replacement in the human stratum corneum in old age. Br. J. Derm., 80:367-372, 1968.

Baker, H. Kligman, A.: Technique for estimation turnover time of human stratum corneum. Arch. Dermato1.,95:408-411, 1967.

Baserga, R.: Biochemistry of the cell cycle. Cell Tissue Kinet. $1: 167-191,1968$.

Baserga, R.: The cell cycle and cancer. Dekker, New York, pag. 197, 1971 .

Bauer, F.W. \& De Grood, R.M.: Impulse cytophotometry in psoriasis. Br. J. Derm., 93:225-227,1975.

Bergstresser, P.R. \& Taylor, J.R.: Epidermal "turnover time"a new examination. Br. J. Derm.,96:503-509,1977.

Bertanlanffy, F.D. \& Leblond, C.P.: The continuous renewal of the two types of alveolar cells in the lung of the rat. Anat. Rec. , 115:515-542,1953.

Born, W. Kalkoff, K.W.: Die gesunde Haut des Psoriatikers in Tritum-thymidine Autoradiogramm. Arch. klin. exp. Derm., $234: 125-132,1969$.

Braun-Falco, O. , Christophers, E. Kurban, A. : Abnomalles Verhalten der epidermalen Regeneration bei Patienten mit psorlasis vulgaris. Arch. klin. exp. Derm., 229:276-284, 1967 .

Brophy, D. \& Lobitz, W.: Injury and reinjury to the human epidermis. 2. epidermal basal cell response. J. Invest. Derm., $32: 495-502,1959$.

Brues, A.: The effect of colchicine on regenerating 1 iver. J. Physiol.,86:63, 1936 . 
Bucher, $0 .:$ Zur Kenntnis der Mitose. 6. Der Einfluss von Colchicin und Tryptaflavin auf den wachstumsrhythmus und auf die zellteilung in Fibrozytenkulturen. Z. F. Zellforsch. Mikr. Anat. 29:283-322, 1939 .

Casperson, T.: Die Untersuchungen der Nukleinsäureverteilung $1 \mathrm{~m}$ Zellkern. Z. Wiss. Mikr.,53:403-419,1936.

Chopra, D.P. \& Flaxman, B.A.: Comparative proliferative kinetics of cells from normal human epldermis and benign hyperplasia (psoriasis) in vitro. Ce11 Tissue kinet.,7:69-76, 1974.

Christophers, E. \& Schaumlöffel, E.: zur DNS-Synthesezeit in der menschlichen Epidermis. Arch. klin. exp. Derm., 228:57-64, 1967 .

Clarkson, B.D., ohkita, T., ota, K. \& Fried, J.: Studies of cellular proliferation in human leukemia I. Estimation of growth rates of leukemic and normal hematopoletic cells in two adults with acute leukemia given single injections of $\mathrm{H}^{3}$-thymidine. J. Clin. Invest. "46:506-529,1967.

Cohn, N. \& van Duyn, P.: Constancy of DNA content in adrenal. medulla nuclei of cold treated rats. J. Ce11 Biol. 33:349354,1967 .

Cooper, Z.K.: Mitotic rythm in human epidermis; introduction and review of 1 iterature. J. Invest. Derm.,2:289-300,1939.

Crissman, H.A. \& Tobey, R.A.: Cell cycle analysis in $20 \mathrm{mi-}$ nutes. Science, 184:1297-1298,1974.

Crissman, H.A., Mullaney, P.F. \& Steinkamp, J.A.: Methods and applications of flow systems for analysis and sorting of mammalian cells. In: Methods in Cell Biology, vol. 9,

(D.M. Prescott, ed.) Academic Press, New York, pag. 179-246, 1975.

Dittrich, W. \& Göhde, W.: Impulsfluorometrie bei Einzelzellen in Suspension. Z. Naturforsch *, 246:360-361, 1969 .

Duffill, M. Wright, N. \& shuster, S.: The cell proliferation kinetics of psoriasis examined by three in vivo techniques. Br. J. Derm., $94: 355-362,1976$.

Duffi11, M. "Appleton, D., Dyson, P. "Shuster, S. \& Wright, N.: The measurement of the cell cycle time in squamous eplthelium using the metaphase arrest technique with vincristine. Br. J. Derm. $96: 493.502,1977$.

Dustin, A. : La colchicine réactive de 1 'imminence caryocinetique. Arch. Portug. Sc. Biol.,5:38-43,1936.

van Duyn, P.: Remarks on the two-wavelengths method. Acta Histochem. Supp1.,6:61-69,1966. 
ElY, J.O. Ross, M.H.: Nuclelc acids and the Feulgen reaction Arat. Rec., 104:103-123,1949.

Eplfanova, O.I. Terskikh, V.V.: On the resting periods in the cell life cycle. Cell Tissue Kinet.,2:75-93,1969.

Epstein, . Maibach, H.: Cell renewal in human epidermis. Arch. Dermato $1 ., 92: 462-468,1965$.

Filkuka, J., Lederer, B. \& Sandritter, W. Loss of basic nuclear protein during fermentative 1 solation of epidermal cells. Acta Histochem. (Jena), 29:263-269,1968.

Fisher, L.: Determination of normal rate and duration of mitosis in human epidermis. Br. J. Derm.,80:24-28,1968.

IFisher, $\mathbb{L} .:$ The diurnal mitotic rythm in the human epidermis. Br. J. Derr., $80: 75-80,1968$.

Fisher, L. \& Wells, C.: The mitotic rate and duration in lesons of psoriasis and ichthyosis. Br. J. Derm.,80:235-240, 1968 .

Zranke, W.W., Deumling, B. Zentgraf, H.: Losses of materill during cytological preparation of nuclei and chromosomes. Exp. Cel1 Res., 80:445-449,1973.

zrost, P., Weinstein, G.D. \& Van scott, E.: The ichthyosiforme dermatoses. J. Invest. Derm. 47:561-567, 1966 .

Galant, S.: Initiation of mitosis in relation to the cell division cycle. Exp. Cell Res.,26:395,1961.

Gelfant, S.: The cell cycle in psoriasis: a reappraisal. Br. J. Derm., $95: 577-590,1976$.

Gerecke, D.: Zux S-Phasenbestimmung mit markierten Mitosen. Naturwissenschaften, $57: 360,1970$.

Glibert, C.W.: The labelled mitosis curve and the estimation of the parameters of the cell cycle. Cell Tissue kinet.,5: $53-63,1972$.

Guvanelda, B.C. \& Heidelberger, C.: Mouse epidermal cells and carcinogenesis. I. Isolation of skin constituents. Cancer Res., 25:161-181,1965.

Goldstein, D.: Aspects of scanning microdensitometry $1 . \mathrm{J}$. Microse. (Oxf), $92: 1-16,1970$.

Goldstein, D.: Aspects of scanning microdensitometry $2 . \mathrm{J}$. Microse. (Oxf), $93: 15-42,1971$.

Goodwin, P. "Hamilton, S. \& Fry, I.: A comparison between DNA synthesis and mitosis in uninvolved and involved psoriatic epidermis. Br. J. Derm.,89:613-618,1973. 
Goodwin, P., Hamilton, S. Fry, L.: The cell cycle in psoriasis. Br. J. Derm., $90: 517-524,1974$.

Greulich, R.C.: Aangehaald in : Epstein, W. \& Maibach, H. : Cell renewal in human epidermis. Arch. Dermatol.,92:462-468, 1965.

Grove, G., Anderton, R. \& Smith, G.: Cytophotometric studies of epidermal proliferation in psoriatic and normal skin. J. Invest. Derm., $66: 236-238,1976$.

Haag, D., Tschahargane, C. \& Ehemann, V.: Isolation of single cell nuclei from human epidermis for cytophotometric DNAmeasurements. Arch. Derm. Res.,253:301-310,1975.

Halprin, K.M.: Epidermal "turnover time" - A re-examination. Br. J. Derm., 86:14-19,1972.

Heenen, M. \& Galand, P.: Cell population kinetics in human epidermis: in vitro autoradiograflc study by doubble labelling method. J. Invest. Derm. $56: 425-429,1971$.

Heenen, M. Achten, G. \& Galand, P.: Autoradiografic analysis of cell kinetics in human normal epidermis and basal carcinoma. Cancer Res. ,33:123-127,1973.

He11, E. \& Hodgson, C.: The uptake of $\mathbb{H}^{3}$-thymidine by epidermal cells in normal and psoriatic subjects. Br. J. Derm.,78: $262-268,1966$.

Hilscher, W. Maurer, W.: Autoradiagrafische Bestimung der Dauer der DNS Verdopplung und ihres zeitlichen Verlaufs bei Spermatogonien der Ratte durch Doppelmarkierung mit C 14 - und $H^{3}$-thymidin. Naturwissenschaften, $49: 352-354,1962$.

Hoffman, J.G.: Quantitative analysis of the growth of epidermis. Arch. Pathol, $47: 37-43,1949$.

Howard, A. \& PeIC, S.R.: Synthesis of desoxyribonuclelc acid in normal and irradiated cells and 1ts relationshlp to chromosome breakage. Heredity, 6 (Suppl.):261-273,1953.

Hudson, B., Upholt, W.B., Divinny, J. \& Vinogard, J.: The use of an Ethidium Bromide analogue in the dye-buyoant density procedure for the isolation of closed circular DNA: The variation of the superhelix density of mitochondrial DNA. Proc. Nat1. Acad. Sci. USA, 62:813-820,1969.

Hulett, H.R., Bonner, W.A., Barret, J. \& Herzenberg, L.A.: Cell sorting: automated separation of mammalian cells as a function of intracellular fluorescence. Science, 166:747-749, 1969.

Iversen, O.H. Evensen, A. : Experimental skin carcinogenesis in mice. Acta Pathol. Microbiol. Scand.,156 (Suppl.): 1-184, pag. 95,1962 . 
Impulscytophotometrie. Herausgegeben von M. Andreeff. Springer-Verlag, Berlin-Heidelberg-New York, 1975.

Jansen, L., Hojyo-Tomoko, M. KI gman, A. : Improved fluorescence staining technique for estimating turnover of the human stratum corneum. BI. J. Derm.,90:9-12,1974.

Joftes, D.: Radiografy, principles and procedures. J. Nucl. Med. , $4: 143-154,1963$.

Kaldby, K. Kurban, A.: Mitotic behaviour of the buccal mucosal epithelium in psorilasis. Br. J. Derm.,85:162-166,1971.

Kaku, H., Igaxashi, Y. Fujita, S.: Cytokinetic analysis of the human skin in vivo in normal and pathological conditions: a $\mathrm{H}^{3}-$ thymidine autoradiografic study. Arch. Histol. Jap.,24: $457-470,1964$.

Kamentsky, L.A.: Spectrophotometer: New instrument for ultrarapid analysis. Sclence, 150:630-631,1965.

Kasten,F.H.: Shiff-type reagents in cytochemistry. Histochemie, $1: 466-509,1959$.

Katzberg, A.A.: The influence of age on the rate of desquamation of the human epidermis. Am. Assoc. Anatom.,112:418, 1952 .

Killmann, S.A., Cronkite, E.P., Robertson, J.S., Fliedner, T. M. Bond, V.P.: Estimation of phases of the life cycle of leukemic cells from labeliing in human beings in vivo with $H^{3}$-thymidine. Lab. Invest. ,12:671-684, 1963 .

Kraemer, P.M., Deaven, L.L., Crissman, H.A. \& Van Dilla, M.A.: DNA-constancy despite variability of chromosome number. In: E.J. Du Praw, Advances in cell and molecular blology. Academic Press, New York, wol. 2:47-107,1972.

Leblond, C.P. \& Stevens, C.E.: The constant renewal of the eplthelium in the albino rat. Ibia.,100:357-378,1948.

Lennartz, K.: Experimentelle Untersuchungen zum Wachstumsverhalten von Tumorzellen. Verh. dtsch. Ges. Path.,51:340343,1967 .

Le Pecq, J.B. Paoletti, C.: A fluorescent complex between ethidium bromide and nucleic acids. J. Mol. Biol.,27:87-106, 1967 .

Lipkin, M.: The proliferative cycle of mammallan cells. In: Baserga, The cel1 cycle and cancer, vol. 1, pag. 1-26,1971.

Ludford, R.: The action of toxic substances upon the division of normal and malignant cells in vitro and in vivo. Arch. Exp. Ze1lforsch. 18:411-441,1936. 
Marks, R.: Epidermal activity in the involved and uninvolved skin of patients with psoriasis. Br. J. Derm.,98:399404,1978 .

Mc Minn, R.M.H.: The rate of renewal of intestinal epitheIium in the cat. J. Anat.,88:527-532,1954.

Mendelsohn, M.: The two-wavelenghts method of miorospectrophotometry 2. J. Biophys. Biochem. Cyto1.,4:415-424,1958.

Milstein, H. \& Corne11, R.: Diurnal mitotic studies of psoriatic epidermis. J. Invest. Derm. ,61:180-182, 1973.

Mullaney, P.F., Van Dilla, M.A., Coulter, J.R. \& Dean, P.N.: Cell sizing: a light scattering photometer for rapid volume determination. Rev. Sci. Instrumen.,40:1029-1032,1969.

Ornstein, L.: The distributional error in microspectrophotometry. Lab. Invest., $1: 250-262,1952$.

Patau, K.: Absorption microphotometry of irregular-shaped objects. Chromosoma, 5:341-362,1952.

Pinkus, H. : Examination of the epidermis by the strip method of removing horny layers. J. Invest. Derm., 19:383-385,1952.

Pinkus, H.: Examination of the epidermis by the strip method 2. J. Invest. Derm.,19:431-447,1952.

Plewig, G., Fulton, H. \& Kligman, A: Cellular dynamics of comedo formation in acne vulgaris. Arch. f. dermat. Forsch., $242: 12-29,1971$.

Porter, D. \& Shuster, S.: A new method for measuring replacement of epidermis and stratum corneum in human skin. J. Invest. Derm., 49:251-255,1967.

Potten, C.S.: Epidermal cell production rates. J. Invest. Derm. ,65:488-500, 1975 .

puck, T.T. \& steffen, J.: Life cycle analysis of mamalian cells. Blophys. J.,3:379-397,1963.

Pullmann, H. : Autoradiographie-Untersuchung der zellproliferation bei psoriasis vulgaris. Grosse scripta 3, Grosse Verlag, Berlin, 1978 .

Pullmann, H., Lennartz, $\mathbb{K}$. \& Steigleder, G.K. : In vitro examination of cell proliferation in normal and psoriatic epidermis with special regard to diurnal variations. Arch. f. dermat. Forsch. $250: 177-184,1974$.

Pulse cytometry, part I, Ed. by C.A.M. Haanen, H.F.P. Hillen \& J.M.C. Wessels, European Press Medikon, Ghent, 1975 . 
Pulse cytometry, part II, Ed. by W. Gohde, J. Schumann \& Th. Btichner, European Press Medikon, Ghent, 1976.

Pulse cytometry, part III, Ea. by D. Lutz, European Press Medikon, Ghent, 1978 .

Pulse cytometry, Flow cytometry 4, proceedings of the 4 th international symposium on flow cytometry, Ed. by Laerum, O.D., Iindmo, T. Thorud, E., Universiteitforlaget oslo, 1979.

Pulse cytophotometry, Abstracts of the fifth international symposium on flow cytometry. Ed. by Mauro, F. \& Mazzini, G., In: Basic and applied histochemistry $24 / 4,1980$.

Pulse cytophotometry, Abstracts of the 6th international symposium on flow cytometry, Ed. by Wheeless, L., Görttler, K. \& Ploem, J.S., 1982 .

Quastler, H.: The analysis of cell population kinetics. In: Cell proliferation, (L.F. Lamerton \& R.J.M. Fry, eds) Blackwe11, Oxford, 1963.

Quastler, H. \& Sherman, F.: Cell population kinetics in the intestinal epithelium of the mouse. Exp. Cell Res.,17:420438,1959 .

Rinaldini, L.M.J.: The isolation of living cells from animal tissues. Int. Rev. Cytol., 7:587-647,1958.

Roenigk, H., Maibach, H. \& Welnstein, G.D.: Methotrexate therapy for psoriasis. Guideline revisions. Arch. Dermatol., $108: 35,1973$.

Rothberg, S., Crounse, R. \& Lee, J.: Glycine-C ${ }^{14}$ incorporation into the proteins of normal stratum corneum and the abnormal stratum corneum of psoriasis. J. Invest. Derm.,37: $497-505,1961$.

Rowe, L., Dixon, W.J. \& Forsythe, A.: Miltoses in normal and psorlatic epidermis. Br. J. Derm.,98:293-299,1978.

Scheving, L.E.: Mitotic activity in the human epidermis. Anat. Rec. $135: 7,1959$.

Schumann, J., Ehring, F., Göhde, W. \& Dittrich, W.: Impulscytophotometrie der DNS in Hauttumoren. Arch. klin. exp. Derm., $239: 377-389,1971$.

Sprenger, E., Böhm, N. \& Sandritter, W.: Durchflussfluorescenzcytophotometrie für ultraschnelle DNS-Messungen an grossen Zellpopulationen. Histochemie, 26:238-257, 1971 . 
Steigleder, G.K. , Schumann, H. Lennartz, K. : Autoradiografic in vitro-examination of psoriatic skin before, during and after dithranol treatement. Arch. f. dermat. Forsch." $246: 231-235,1973$.

Stevens Hooper, C.: Use of colchicine for the measurement of mitotic rate in the intestinal epithelium. Am. J. Anat." $108: 231-244,1961$.

Sutton, R.L.: Early epidermal neoplasia, Arch. Derm. Syph." $37: 742-780,1938$.

Takahashi, M.: Theoretical basis for cell cycle analysis. I. labelled mitosis wave method. J. Theoret. Biol.,13:202-211, 1966.

Thuringer, J.M.: Studies on cell division in the human epidermis. Anat. Rec., 40:1-13,1928.

Trujillo, T.T. \& Van Dilla, M.A.: Adaptation of the fluorescent feulgen reaction to cells in suspension for flow microfluorometry. Acta Cytol.,16:26-30,1972.

Van Dilla, M.A., Mullaney, P.F. \& Coulter, J.R.: Los Alamos scientific laboratory report LA-3848-Ms, pag.100, National Technical Information Service, Us Derpartment of Commerce, Springfield, Virginia, 1967.

Van Dilla, M.A., Truj1110, T.T., Mullaney, P.F. \& Coulter, J.R. : Cell microfluorometry: a method for rapid fluorescence measurement. Science, $163: 1213-1214,1969$.

Van Scott, E. \& Ekel, T.: Kinetics of hyperplasia in psoriasis. Arch. Dermatol, 88:67-75,1963.

Vendrely, C.: Cytophotometry and histochemistry of the cell cycle. In: The cell cycle and cancer, Ed. by $\mathbb{R}$. Baserga, Dekker, New York, 227-268, 1971 .

van Vloten, W.A.: De betekenis van DNA cytofotometrie voor de vroegtijaige diagnostiek van mycosis fungoides. Proefschrift, Leiden, 1974 .

Vulpé, M.: The renewal of the eplthelium of the urinary bladder. Thesis, Montreal, 1954.

Ward, D.C., Reich, E. \& Goldberg, I.H.: Base speciflcity in the interaction of polynucleotides with antibiotic drugs. Science, 149:1259-1263,1965.

Weinstein, G.D.: Autoradiografic studies of turnover time and protein synthesis in pig epidermis. J. Invest. Derm., $4: 4: 413-419,1965$.

Weinstein, G.D.: Biochemical and pathophysiological rationale for methotrexate in psoriasis. Ann. NY Acad. Sci.,186: $452-466,1971$. 
Welnsteln, G.D. Frost, P.: Abnomal cell proliferation in psoriasis. J. Invest. Derm., 50:254-259,1968.

Weinstein, G.D. \& Frost, P.: Cell proliferation kinetics in benign and malignant skin diseases in humans. Nat. Cancer Inst. Monogr , 30:225-246,1969.

Weinstein, G.D. Frost, P.: Methotrexate for psoriasis: a new therapeutic schedule. Arch. Dermatol.,103:33-38,1971.

Weinstein G.D. \& MC Cullough, J.L." Cytokinetics in diseases of epidermal hyperplasia. Ann. Rev. Med.,24:245-252,1973.

Weinstein G.D. \& MC Cullough, J.L. : Cytokinetics and chemotherapy of psoriasis. J. Invest. Derm.,67:26-30,1976.

Weinstein, G.D. \& Van Scott, E.: Autoradiografic analysis of turnover times of normal and psoriatic epidermis. J. Invest. Derm. 45:257-262,1965.

Weinstein, G.D. "Roenigk, H.H., Maibach, H.I. \& Auerbach, R.: Methotrexate guddelines-update 1981. In: Psoriasis, proceedings of the third international symposium.Ed. by Farber, E.M. Cox, A.J., pag. 395-396, 1981 .

Wimbler, D. Quastler, H. A $\mathrm{C}^{14}$ - and $\mathrm{H}^{3}$-thymidine double labeling technique in the study of cell proliferation in "Trasdescantia root tips. Exp. Ce11 Res., 30:8-22,1963.

Wright, N.: Cell population kinetics in human epidermis. Int. J. Derm., 16:449-463,1977.

Wüthner, K., Sachs, H. \& Bahnsen, J.: Zum Problem der Kernanschnitte bei der zytophotometrie an histologischen Präparaten. Histochemie, $32: 261-270,1972$. 
FLOWCYTOMETRIE: DE METHODE VAN ONDERZOER.

3.1. Inleiding

3.2. Elowcytometer

3.3. Afname techniek

3.4. Bewerking wan het monster

3.5. Analyse van de gegevens

3.5.1. Histogram

3.5.2. Mathematische analyse

3.5.3. Colncidentie

3.6. Moeilijkheden bij de interpretatie

3.6.1. Klontjes

3.6.2. Celbeschadiging, onvolledige kleuring en asymmetrie

3.6.3. Correlatie met celcyclus-en turnovertija

3.7. Referenties. 
FLOWCYTOMETRIE: DE METHODE VAN ONDERZOEK.

\section{1. INLEIDING.}

In hoofdstuk 2 hebben we een overzicht van diverse methoden ter bestudering van de celkinetiek gegeven. Toepassing van deze methoden bij de bestudering van de kinetiek van normale en psoriasis epidermis brengt aanzienlijke verschillen en tegenstrijdigheden aan het licht.

Flowcytometrie, die sedert kort ook in de dermatologle wordt toegepast, kan op grond van een aantal in hoofdstuk 2 genoemde argumenten de mogelijkheid bieden ons inzicht in de epidermale celgroei te verdiepen.

Dit hoofdstuk geeft een overzicht van de door ons gebrujkte apparatuur en preparatiemethode en behandel.t een aantal moeilijkheden bij de analyse en de interpretatie van de verkregen gegevens.

\section{2. FLOWCYTOMETER.}

De in dit proefschrift gebruikte flowcytometer is de I.C.P. 11 (PhYwe, Göttingen, B.R.D.). Onderstande fjguren 3.2.1. en 3.2 .2 . geven een vereenvoudigde schematische voorstelling van de flowcytometer en de randapparatuur. Alle stappen van het meetproces zijn geautomatiseerd.

De cellen waarvan het DNA kwantitatief aan het Eluorochroom propidium jodide is gebonden, worden opgezogen via een capillair naar het dieptescherpteveld van een microscoop-cytometer. De belichting van dit veld geschiedt door een hogedruk kwiklamp (HBO $100 \mathrm{~W} /$ Osram). Van het emmissiespectrum van deze lamp wordt door een aantal filters een zodanlg spectrum gekozen dat het fluorochroom wordt geexciteerd. Elke fluorochroom bevattende cel zendt, wanneer ze de meetopening passeert, emissielicht uit. Dit fluorescentiesignaal wordt door een photomultiplier omgezet in een electrisch signaal. De intensiteit van het emisilelicht en derhalve ook de grootte van het electrisch signaal is evenredig met de hoeveelheid fluorochroom, derhalve met de hoeveelheid DNA. De electrische signalen worden versterkt, naar grootte gesorteerd in $128 \mathrm{klassen}$ en opgeslagen in het geheugen van een veelkanals pulse-hoogte analysator.

Het aantal cellen in elk kanaalnummer wordt uitgelezen en overgebracht nar een rekenmachine (Hewlett-Packard $9810 \mathrm{~A}$ calculator plotter control block) door middel van een interface (eigenbouw, afdeling electronica, Med.Fac.,K.U.N.). De gegevens kunnen worden gepresenteerd in de vorm van een histogram met behulp van een plotter (Helwett-Packard 9862 
Eiguur 3.2 .1 .

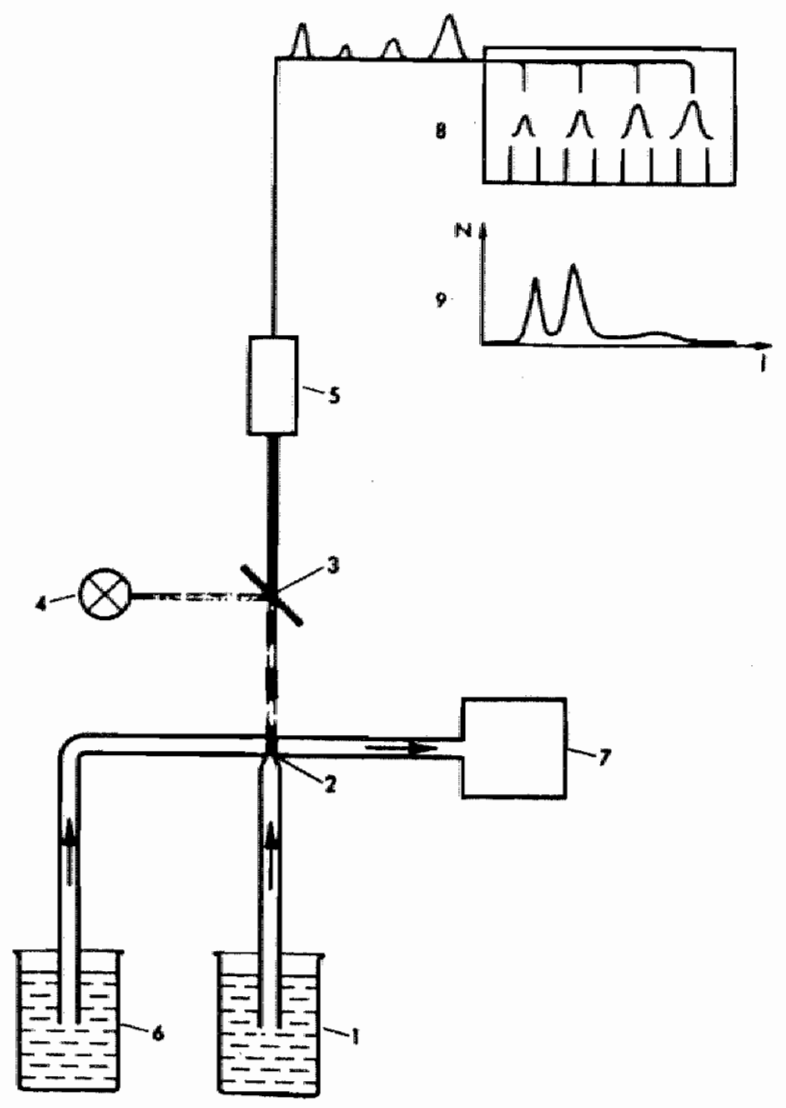

Eiguur 3.2.1.: Schematische voorstelding van het optische en electronische gedeelte van de I.C.P. 11 flowcytometer (naar Hillen, 1975).

1. celsuspensie

2. meetveld

3. fluorescentie microscoop

4. hoge aruk kwik lamp

5. photomultiplier

6. vloeistof reservoir

7. zuigpomp

8. puls hoogte analysator

9. histogram 
A calculator plotter). De analyse van de gegevens vindt plaats door middel van een rekenprogramma (zie 3.5.2.). Via een tape puncher (Hewlett-Packard 9884 A tape punch) bestaat de mogelijkheid tot verdere datamanipulatie door middel van een PDP $11 / 45$ en I.B.M. 370 computer.

De optiek van de flowcytometer wordt voor ellke meting of serie metingen geijkt. Dit gebeurt door de optiek optimal in te stellen met behulp van een standaard celsuspensie van kippe-erythrocyten in propidium jodide.

Figuur 3.2.2.

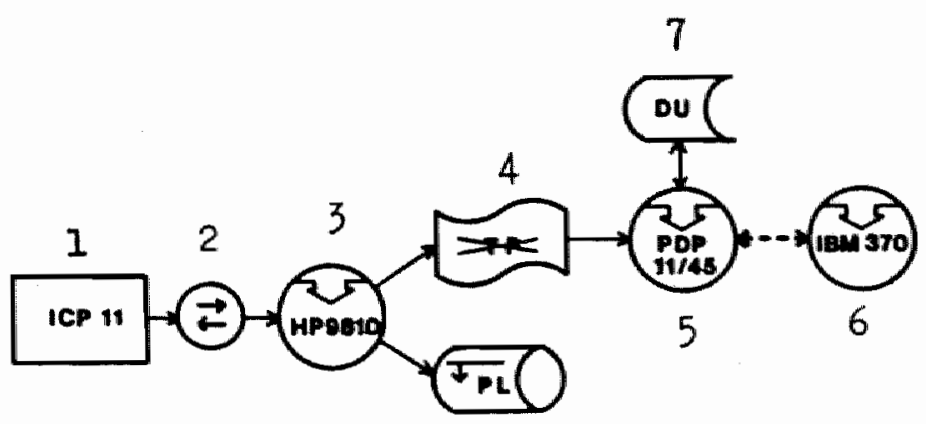

8

Figuur 3.2.2.: Schematische voorstelling van de flowcytometer en de randapparatuur.

1. I.C.P. 11 flowcytometer

2. interface

3. Hewlett-packerd 9810 A calculator plotter control block

4. Hewlett-Packerd 9884 A tape punch

5. PDP $11 / 45$ computer

6. IBM 370 computer

7. magnetische schijven

8. Hewlett-Packerd 9862 A calculator plotter 
De gebruikte techniek is de door Bauer \& De Grood (1976) ontwikkelale methode, warbij een dunne metaalstrip op de huid wordt gedrukt. De te onderzoeken huid, die opbolt door een gat van $5 \mathrm{~mm}$ diameter in het metaal, wordt met een scheermes verwijderd. De biopsie heeft gemiddeld een diameter van 2-3 $\mathrm{mm}$ en een dikte van $\pm 0,3 \mathrm{~mm}$. Bij histologische controle blijken deze biopsieën ruim de gehele epidermis te bevatten. De veroorzaakte excoriaties worden angestipt met ferrichloride.

\section{4. BEWERKING VAN HET MONSTER.}

Incubatie van het afgenomen stukje huid vindt plats gedurende twintig minuten bij $37^{\circ} \mathrm{C}$ in een $0,15 \mathrm{M}$ fosfatbuffer $\left(0,15 \mathrm{M} \mathrm{Na}_{2} \mathrm{HPO}_{4}, 0,15 \mathrm{M} \mathrm{NaH}_{2} \mathrm{PO}_{4}, \mathrm{pH}=7,8\right)$, die tevens 18 trypsine (Difco $1: 250$ ) en 0,38 dithioerythritol (Sigma D-8255) bevat. Dithioerythritol reduceert de disulfide bruggen tot sulfhydryl groepen en draagt zo bij tot vernietiging of homogenisatie van de desmosomen van de keratinocyten en de basaalmembraan (Kobayasi et al.,1977). Het proteolytische enzym trypsine breekt de desmosomen verder af, terwijl celmembranen, organellen en nuclei intact blijven (Hentzer et al.,1976). De "intacte" monsters worden na incubatie gebracht in enkele druppels propidium jodide (1 mgr/ $100 \mathrm{mll}$ opgelost in bovengenoemde fosfaatbuffer. Door enkele seconden ultrasoon te trillen $170 \mathrm{~W}$, Sonifier $\mathrm{B} 12$, Branson sonic power company, Danbury, Connecticut), wordt de epidermis van de dermis gescheiden en worden de epidermiscellen in suspensie gebracht. Het uiteindelijke volume propidium jodide wordt op een zodanig volume gebracht dat de frequentie van de te tellen cellen \pm 300 cellen per seconde bedraagt. De celmembraan wordt permeabel gemaakt voor het fluorochroom door twee druppels dimethylsulfoxide (Merck $2951)$ toe te voegen. Na filtratie door een nylon gaas ( $\pm 70 \mathrm{mu}$ ) wordt een overmaat ribonuclease 14 druppels van een oplossing van $10 \mathrm{mgr} / \mathrm{ml}$ aq.dest., Ribonuclease-A, Sigma $R$ 4875, 76 Kundtz units/mgr) toegevoegd om eventuele aspeclfleke kleuring van RNA te elimineren.

De gehele bovenbeschreven procedure beslaat \pm 30 minuten. Het celverlies is minimal omat geen centrifugatiestappen nodig zijn (Bauer \& De Grood, 1976). Om distributiefouten doar onvolledige kleuring te voorkomen wordt een tijdsinterval van minimal 1 uur aangehouden tussen toevoeging van de propidium jodide en het moment van meting. De suspensie is tenminste 24 uur houdbaar b1j $4^{\circ} \mathrm{C}$ zonder dat dit invloed heeft op de kwaliteit van het histogram of op de kwantiteit van de aryalyse.

Met trypsine, gecombineerd met dithioerythritol, worden goede celsuspensies, zowel van normale als van abnormale epi 4 dermis verkregen, waaruit zonder problemen $2 \times 10^{5}$ cellen kunnen worden getela. Incubatie met pepsine is overwogen; ook hiermee wordt een goede dissociatie van de epidermiscellen verkregen. Op grond 
Figuur $3.5 \cdot 1.1$.

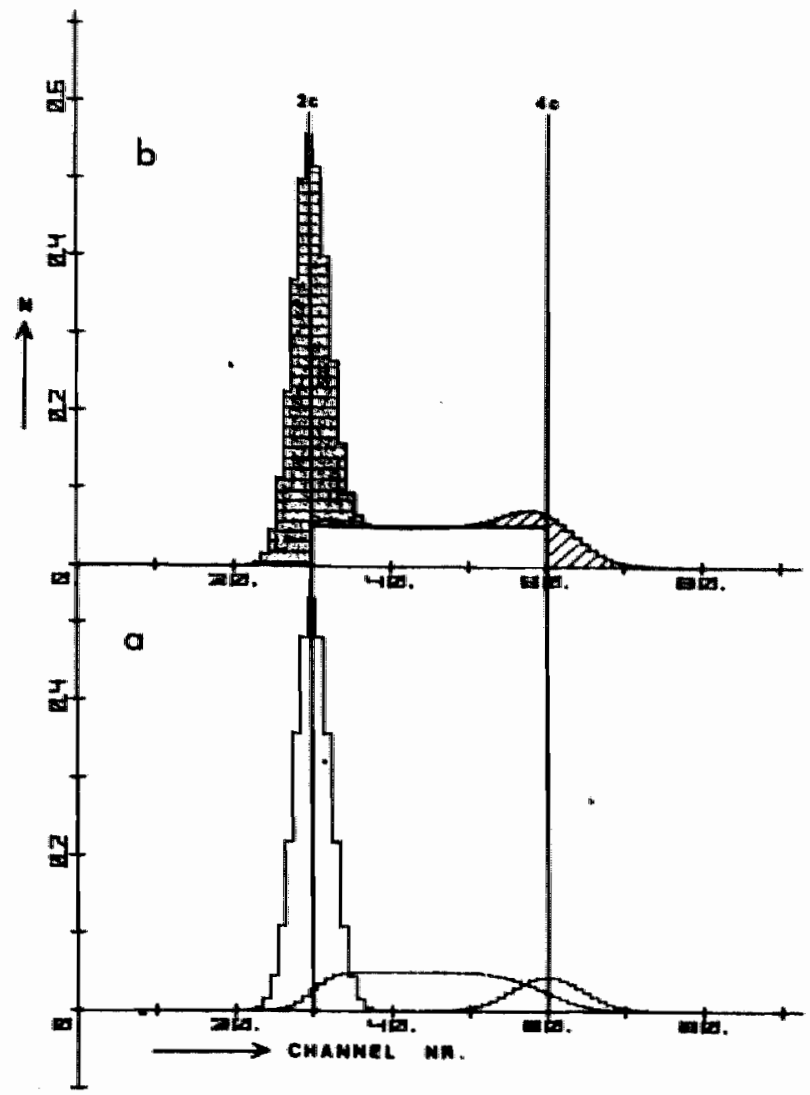

Figuur 3.5.1.1.: Figuur a geeft de verdelingen van de $2 \mathrm{c}$, $2 \mathrm{c}-4 \mathrm{c}$ en $4 \mathrm{c}$ cellen weer. Flguur b geeft de samengestelde verdeling weer. Het $G_{2} M$ maximum is naar links verschoven. Het percentage $2 \mathrm{c}$ cellen wordt verkregen uit integratie van het gearceerde gebied. Het percentage $\mathrm{G}_{2} \mathrm{M}$ uit integratie van het gestreepte gebied. De rechthoek tussen het $2 \mathrm{c}$-maximum en het dubbele van het 2c-maximum en de hoogte van het plateau tussen de $2 \mathrm{c}$ en $4 \mathrm{c}$ plek vormt het percentage s cellen. 
Eiguur 3.5 .1 .2 .

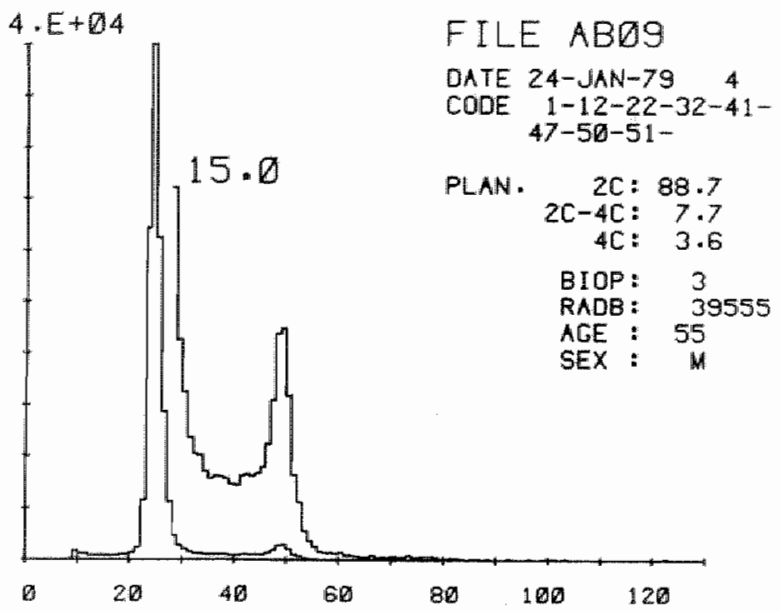

Figuur 3.5.1.2.: Representatief DNA histogram van normale humane epidermis. Totale aantal gemeten cellen: 128.956 .

van de histogrammen is voor deze methode niet gekozen omat klontjesvorming optreedt. Ook worden de cellen in de mitosefase door het pepsine beschadigd (Beck, 1977). Hierdoor wordt de grootte van de $4 c$ fractie beinvloed.

Bij de infiltratie blijft het stratum corneum als een dun viles en de dermis als een weefselflard in het filter achter. Histologische controle van de dermis toont an dat er geen epidermiscelien meer aan vast zitten. ook aan het stratum corneum hechten geen epidermiscellen meer. 
1.5.1. HISTOGRAM.

Het histogram wordt verkregen door het aantal cellen uit te zetten als functle van de 128 DNA klassen.

Het DNA gehalte van normale humane diplolde cellen is constant (Vendrely,1971; kraemer et al. 1972). In theorie komen derhalve alle cellen in een homogene populatie met $2 \mathrm{c}$ DNA in Én kanaalnummer. Op grond van een aantal fouten (preparatieve, kleuring, optische en electronische fouten) treedt er een meer of minder brede verdeling rond het gemiddelde op, uitgedrukt in de variatiecoëfficient (c.v.). Deze coëfficient ligt in onze experimenten rond de 5-7\%. De variatiecoéficient is bij de flowoytometrische methode veel kleiner dan die bij de statische cytometrie (kraemer et al. ,1972; Golhde,1973).

Door het voltage van de photomultiplier te veranderen kan de $2 \mathrm{c}$ piek in een willekeurig kanaalnummer worden geplaatst. Cellen met de dubbele hoeveelheid DNA komen in het dubbele kanaalnummer. Cellen met DNA hoeveelheden tussen $2 \mathrm{c}$ en $4 \mathrm{c}$ komen in het tussenliggende gebied. Omat de verdeling van de $2 c$ cellen het begin van de verdeling van de $s$ fase cellen en de verdeling van de cellen in de $4 c$ plek het einde van de verdeling van de $s$ fase cellen overlapt, schuiven de $2 \mathrm{c}$ en $4 \mathrm{c}$ piek naar elkaar toe, afhankelijk van de groot-. te van de diverse fracties. (figuur 3.5.1.1.). Figuur 3.5.1.2. geeft een representatief voorbeeld van een histogram.

\subsubsection{MATHEMATISCHE ANALYSE.}

Het percentage cellen in de verschillende fasen van de celcyclus kan worden berekend met behulp van diverse mathematische methoden (Dean \& Jett, 1974; Baisch Linden,1975; Baisch et al.,1975). De hier gebruikte analyse is een modiflcatie van de oorspronkelijk door Göhde (1973) voorgestelde planimetrische methode. Deze methode is gebaseerd op de veronderstelling dat de verdelingen verdelingen valgens Gauss zijn en dat de snelheid van synthese door de $\mathrm{S}$ fase Iineair is. In dat geval wordt de vorm van de curve van de cellen in de $S$ fase benaderd door een rechthoek tussen het $2 \mathrm{c}$-maximum en het dubbele van het $2 \mathrm{c}$-maximum. De hoogte van 
de rechthoek wordt gevormd door het plateau tussen $2 \mathrm{c}$ en $4 \mathrm{c}$ in het histogram. uit flguux 3.5.1.1. blijkt dat deze hoogte de hoogte van het $S$ fase plateau benadert. Het percentage $2 \mathrm{c}$ cellen wordt verkregen door het gestippelde oppervlak van het histogram te integrexen. Het percentage $4 c$ cellen wordt verkregen door integratie van het gestreepte gebied.

Het verschil met het Gobde-model is dat in zijn model de rechthoek wordt getrokken door de $2 \mathrm{c}$ en $4 \mathrm{c}$ maxima. Het grote voordeel van de planimetrische methode is de eenvoud. De verkregen resultaten met het Göhde-model stemmen, mits an een aantal voorwaarden wordt voldaan, overeen met de percentages verkregen met complexe computerprogramma's (Baisch et a. $1 ., 1975)$.

Een van deze voorwarden is een niet te grote variatiecoëfficient. De onderstaande tabel 3.5.2.1. geeft de gemeten percentages weer bij de diverse variatiecoëfficienten. Bij een coëfficient van $10 \%$ wijken de percentages niet meer dan \pm 5 af. De plotter control black is bij anze experimenten zo geprogrammeerd dat bij een $\mathrm{C.v}$. van meer dan $10 \%$ de $\mathrm{di}-$ verse fracties niet meer worden berekend.

De invloed van het percentage van de $S$ fase cellen op de diverse metingen is ook uit tabel 3.5.2.1. af te leiden. Hierbij blijken de percentages $S$ in de orde van grootte warin het percentage $S$ in de epidermis varieert, geen wezenlijke afwijking van het thearetische percentage te geven. De met ons gemodificeerd model verkregen resultaten stemmen beter overeen met de theoretische warden dan die met het door Gơde voorgestelde model. Onze apparatuur geeft de percentages in 1 cijfer achter de komma aan.

\section{5. 3. COINCTDENTIE.}

Het probleem van de colncidentie is voor het eerst beschreven door Gohde et al. (1976). Alle te meten cellen bevinden zich in een waterige oplossing en passeren het meetveld met een in meerdere of mindere mate constante snelheid. Indien de ruimte tussen de partikels groot genoeg is worden $z i j$ geregistreerd als aparte signalen. Wanneer twee partikels zo snel na elkaar komen dat de signalen elkaar overlappen kan de photomultipliex deze niet meer scheiden in twee aparte signalen, maar wordt én groter signaal geregistreerd. Dit signaal zal een warde tussen $2 \mathrm{c}$ en $4 \mathrm{c}$ hebben. Door coIncidentie worden derhalve ten onrechte signalen in het " $S$ " gebled geplaatst. In het extreme geval dat de twee signalen geheel samenvallen wordt het geregistreerde signaal in de $4 \mathrm{c}$ piek geplaatst.

De mate van coincidentie is afhankelijk van de pulse rate en de breedte van het signaal. Directe meting van deze twee parameters zou het mogelijk maken een correctiefactor in 
Tabel 3.5.2.1.

THEORETI SCHE WAARDE

GEVONDEN WAARDE

"BOEZEMAN-DE JONGH"

\begin{tabular}{|c|c|c|c|c|c|c|}
\hline C.V. & $\mathrm{G}_{1}$ & $s$ & $\mathrm{G}_{2}$ & $\mathrm{G}_{1}$ & $S$ & $\mathrm{G}_{2} \mathrm{M}$ \\
\hline$=0.05$ & 95 & 4 & 1 & 95.011 & 4.010 & 0.979 \\
\hline$=0.075$ & 95 & 4 & 1 & 95.023 & 4.023 & 0.954 \\
\hline$=0.10$ & 95 & 4 & 1 & 95.024 & 4.084 & 0.892 \\
\hline \multicolumn{7}{|c|}{ 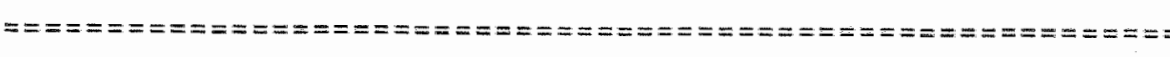 } \\
\hline$=0.05$ & 85 & 10 & 5 & 85.026 & 10.025 & 4.949 \\
\hline$=0.075$ & 85 & 10 & 5 & 85.054 & 10.066 & 4.880 \\
\hline$=0.10$ & 85 & 10 & 5 & 85.027 & 10.300 & 4.673 \\
\hline \multicolumn{7}{|c|}{ 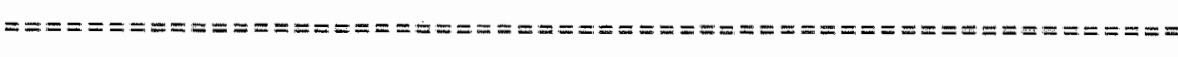 } \\
\hline$=0.0 .5$ & 80 & 15 & 5 & 80.039 & 15.037 & 4.924 \\
\hline$=0.075$ & 80 & 15 & 5 & 80.083 & 15.094 & 4.823 \\
\hline$=0.10$ & 80 & 15 & 5 & 80.092 & $15 \cdot 320$ & 4.588 \\
\hline \multicolumn{7}{|c|}{ 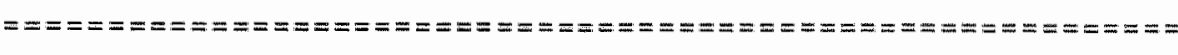 } \\
\hline$=0.05$ & 75 & 20 & 5 & 75.051 & 20.050 & 4.899 \\
\hline$=0.10$ & 75 & 20 & 5 & $75 \cdot 148$ & 20.357 & 4.494 \\
\hline \multicolumn{7}{|c|}{ 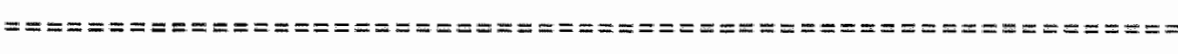 } \\
\hline$=0.05$ & 80 & 10 & 10 & 80.026 & 10.025 & 9.949 \\
\hline$=0.10$ & 80 & 10 & 10 & 79.990 & 10.410 & 9.599 \\
\hline \multicolumn{7}{|c|}{ 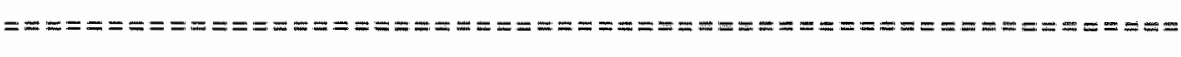 } \\
\hline$=0.05$ & 70 & 20 & 10 & 70.051 & 20.050 & 9.899 \\
\hline$=0.10$ & 70 & 20 & 10 & 70.106 & 20.480 & 9.414 \\
\hline \multicolumn{7}{|c|}{ 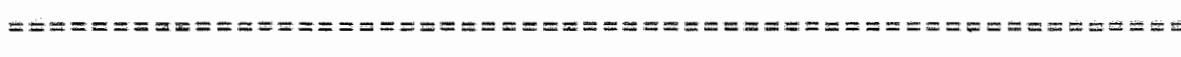 } \\
\hline$=0.05$ & 70 & 10 & 20 & 70.034 & 10.000 & 19.968 \\
\hline$=0.10$ & 70 & 10 & 20 & 69.921 & 10.620 & 19.459 \\
\hline \multicolumn{7}{|c|}{ 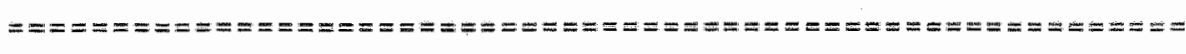 } \\
\hline$=0.05$ & 60 & 20 & 20 & 60.051 & 20.050 & 19.899 \\
\hline$=0.10$ & 60 & 20 & 20 & 60.036 & 20.690 & 19.273 \\
\hline
\end{tabular}

Tabel 3.5.2.1.: Overzicht van de met het door Boezeman \& De Jong gemodificeerde planimetrische model gevonden percentages voor de diverse Eracties bij de diverse variatiecoëfficienten (c. v.) en de diverse theoretische waarden voor de fracties van de celcyclus. 
te voeren. Ondat de I.C.F. 11. apparatuur geen mogelijkheid biedt de signalbreedte te meten moet voor de colncidentie worden gecorrigeerd met behulp van calibratie curven. Voor het maken van deze calibratiecurven is het effect van de pullse rate op het percentage kippe-erythrocyten, dat wordt geregistreerd met een DNA warde tussen $2 c$ en $4 c$, nagegaan. Kippe-erythrocyten behoren in het perifere bloed niet meer te delen en moeten derhalve alle eenzelfde $2 c$ hoeveelheid DNA hebben. Desalniettemin stijgt het aantal signalen, dat geregistreerd wordt met een DNA hoeveelheld tussen $2 \mathrm{c}$ en $4 \mathrm{c}$, lineair van $0,3 \%$ bij 100 cellen per seconde tot $3 \%$ bij een pulse rate van 1000 cellen per seconde. Op analoge wijze is ook het effect var de pulse rate op het "percentage $S$ " nagegaan voor humane epidermiscellen en perifere leukocyten.

In figuur 3.5.3.1. worden de verschillende curves weergegeven. Het snijpunt met de $Y$ as is het werkelijke percentage cellen met $2 \mathrm{c}-4 \mathrm{c}$ DNA warden. De helling van de verkregen curve varieert een weinig van ijking tot ijking, afliankelijk van verschilien in het flowsysteem hetgeen resulteert in veranderingen in signalbreedte.

Piguar 3.5 .3 .1$.

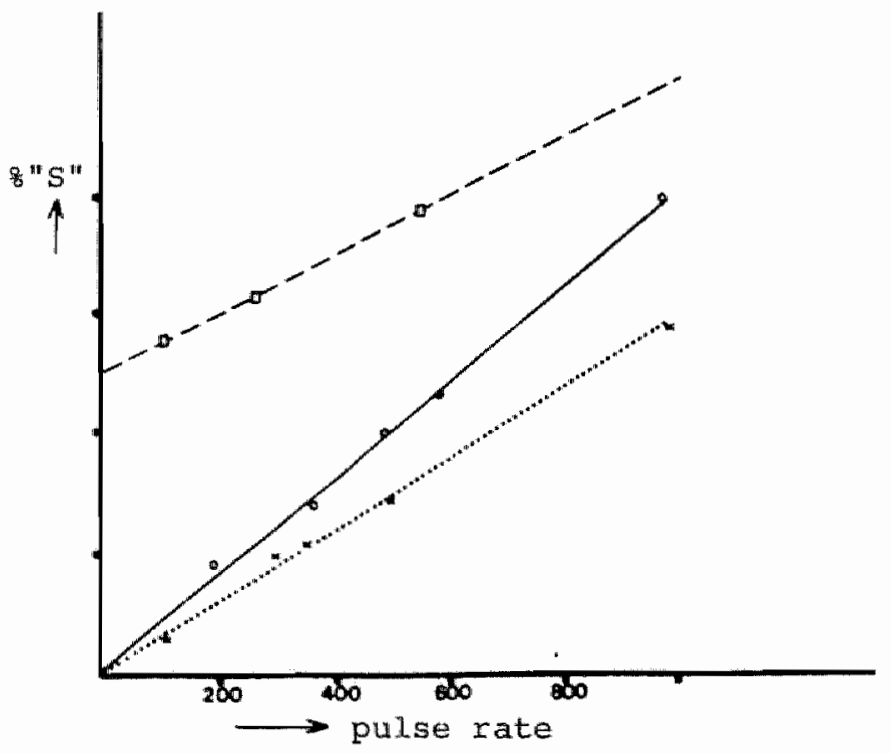

Figuur 3.5.3.1.: Het effect van de pulse rate (cellen per seconde) op het percentage geregistreerde signalen met een DNA hoeveelheid tussen $2 c$ en $4 c\left(8 " S^{\prime \prime}\right)$. $x . . . . x=$ kippe-erythrocyten; $0-0$ - perifere levicocyten;

$-\cdots--$ humane epidermiscellen. 
Calibratie curven voor humane epidermismonsters kunnen niet routinematig worden gemakt omdat hiervoor aanieniljke hoeveelheden material nodig zijn. Derhalve geven we de voor keur aan een correctiefactor die is afgelleid van de calibratie curve van kippe-erythrocyten of perifere leukocyten. De in dit proefschrift gebruikte correctiefactor bedraagt $0,3 \%$ voor de $S$ fractie en 0,128 voor de $G_{2}$ fractie per pulse rate van 100 cellen per seconde. De gecorrigeerde percentages worden derhalve aldus berekend:

gecorrigeerd $\mathrm{S}=$ gemeten $\mathrm{s}$ minus $0,38 \mathrm{x}$ pulse $\frac{1}{10} \overline{0}$ ate gecorrigeerd $G_{2} M=$ gemeten $G_{2} M$ minus $0,128 \times$ pulse $\frac{x a t e}{100}$

De relatieve fout in de gemeten waarden voor de $s$ fractie voor normale epidermis kan zeer aanzienlijk zijn (tot \pm $100 \%$. Derhalve kunnen de warden voor celcyclustijd en turnovertijd, die gebaseerd zijn op de ongecorrigeerde waarden voor het percentage $S$, aanmerkelijk te laag worden geschat. Voor psoriasiscellen met hun veel hoger percentage $S$ en $G_{2}$ is de relatieve fout veel kleiner.

6. MOEILIJKHEDEN BIJ DE INTERPRETATIE.

6.1. KLONTJES.

Met de flowcytometer kan geen onderscheid worden gemakt tussen eén cel met $4 \mathrm{c}$ BNA en een kiontje van twee cellen, elk met 2c DNA. Analoog is er geen verschil tussen octoploide cellen en een klontje van vier diplolde cellen. Om het percentage $4 \mathrm{c}$ cellen niet te hoog te schatten is het noodzakelijk bij het prepareren van het monster zoveel mogelijk losse cellen te verkrijgen.

In de histogrammen van suspensies van kippe-erythrocyten, bereld volgens de normale procedure, die voor elke serie metingen zijn gemaakt ter optimale insteliling van de apparatuur, zijn pieken bij $4 \mathrm{c}$, $6 \mathrm{c}$ en $8 \mathrm{c}$ waarneembaar. In het perifexe bloed delen de erythrocyten niet meer. De pleken bij $4 c, 6 \mathrm{c}$ en $8 \mathrm{c}$ reprensenteren derhalve klontjes van twee, resp. drie, resp. vier cellen. Na ultrasone trilling $(80 \mathrm{~W}$, 10 sec.) is de klontjesvorming steeds sterk afgenomen. onder bepaalde preparatieve omstandigheden komen ook in suspensies van epidermiscellen klontjes voor. Dit betekent dat de $4 \mathrm{c}$ piek bestaat uit cellen met 40 DNA (echte $\mathrm{G}_{2}$ M cellen) en klontjes van twee diploide cellen. Wanneer echter klontjes van twee voorkomen, zullen ook in een bepaalde verhouding klontjes van drie en vier cellen voorkomen. De bijarage door klontjes aan de $4 c$ piek kan worden bepaald uit de verhouding van de $4 \mathrm{c}, 6 \mathrm{c}$ en $8 \mathrm{c}$ pleken voor en na ultrasoon trilllen (Bauer, persoonlijke mededeling). Met deze correctie- 
factor kan het percentage cellen in de $G_{2}$ fractie zonodig worden gecorrigeerd. In het algemeen is het voorkomen van klontjes in de histogramen te verwarlozen wanneer de epidermiscelsuspensies op bovenbeschreven wijze zijn bereid.

\subsubsection{CELBESCHADIGING, ONVOLLEDIGE KLEURING EN ASYMMETRIE.}

Wanneer de cellen en nuclei kapot gaan zullen er brokstukken ontstan met een DNA warde kleiner dan $2 \mathrm{c}$. Dit uit zich in een voorpiek of in een asymmetrische linker schouder van de 20 plek. Ook klontjes fluorochroom of verontreinigde partikels komen hier terecht. Met onze standaard preparatieve methode hebben we bij normale epidermiscellen nauwelijks last van afbraak. Bij epldermiscellen uit een psoriasislaesie is dit in het algemeen in geringe mate het geval. Bij de analyse wordt de voorpiek geheel geëlimineerd. Een asymmetrische schouder is echter een foutenbron, ondat de analyse is gebaseexd op de veronderstelling dat de verdelingen verdeilingen volgens Gauss zijn. Extreme afbraak in de vorm van een asymmetrische linker flank betekent dat het histogram met de door ons gebruikte rekenmethode niet kan worden geanalyseerd. Bij deze histogrammen zijn dan ook de diverse fracties niet berekend.

onvolledige kleuring uit $z$ ich bij onze standaard methode in een asymmetrische rechter schouder van de 20 piek. Dit probleem wordt vrijwel geheel uitgeschakeld door een tijasinterval van 1 uur tussen toevoeging van het fluorochroom en het moment van meting aan te houden.

Asymmetrie van de rechter schouder van de $2 \mathrm{c}$ piek kan ook worden veroorzaakt door een niet-lineaire progressie van de cellen door de $S$ fase of door synchronisatie van een gedeelte van de proliferatieve cellen. Ook in dit geval kunnen de percentages van de diverse fracties niet op standaard manier worden berekend.

\subsubsection{CORRELATIE MET CELCYCLUS- EN TURNOVERTIJD.}

Met de hier gebruikte procedure worden alle levende epidermiscelien in oplossing gebracht. De celsuspensie bestat derhalve uit de prollferatieve celpopulatie en de gedifferentieerde cellen. De gedifferentieerde cellen hebben een $2 c$ DNA warde, evenals de $G$ cellen, en worden door de flowcytometer derhalve niet geschelden op grond van hun DNA gehalte. De percentages $S$ en $\mathrm{G}_{2} \mathrm{M}$ hebben dus betrekling op de gehele celpopulatie. Wil men de gemeten percentages $S$ en $\mathrm{G}_{2} \mathrm{M}$ relateren aan de proliferatieve cellen, dan moet men het aandeel van de proliferatieve cellen in de totale populatie kennen. In de literatuur wordt voor de normale huid vermeld dat dit aandeel \pm 30 \% bedraagt (Halprin, 1972). Voor psoriasis is deze warde niet met zekerheid bekend. Uit de histologie van psoriasis kan men afleiden dat het aandeel van de proliferatieve cellen in een vol ontwikkelde laesie beduidend groter moet zijn. Welnstein \& Housman (1972) veronderstellen dat in een psoriasislaesie het aantal prolifererende cellen 
even groot is als het aantal gedifferentieerde cellen. Bij de flowcytometrie wordt de hoeveelheid DNA van de cellen en niet, zoals bij autoradiografie, de DNA synthese gemeten. Naar alie waarschijnlijkheid echter zal een cel met een DNA hoeveelheid tussen $2 \mathrm{c}$ en $4 \mathrm{c}$ een cel zijn die DNA synthetiseert.

Uitgaande van deze feiten geldt, wanneer men kijkt naar het aantal cellen met DNA waarden tussen $2 \mathrm{c}$ en $4 \mathrm{c}$ ( 85 ), dat:

$$
\mathrm{S}=-\frac{\mathrm{N}_{\mathrm{s}}}{\mathrm{N}_{\text {tot }}} \times 100
$$

Gerelateerd aan de cellen in de celcyclus,

$$
\approx \mathrm{S}^{\prime}=-\frac{\mathrm{N}_{\mathrm{S}}}{\mathrm{N}_{\text {Cycl }}} \times 100
$$

Uit (1) en (2) volgt:

$$
S^{\prime}=-\frac{N_{\text {cycl }}}{\text { tot }_{\text {cycl }}} \times S^{\prime}
$$

In deze formule staat $\mathrm{N}_{\mathrm{Cycl}} / \mathrm{N}_{\text {tot }}$ voor de groeifractie. Deze groeifractie is hiel gedefinieerd als dat deel van het totale aantal kernhoudende cellen, dat de celcyclus daadwerkelijk doorloopt en niet als het deel van de basale cellen dat prolifereert.

De relatie tussen de turnovertijd van de levende epidermis lide tijd die nodig is voor het produceren van een antal cellen gelijk aan de grootte van het compartiment) en de celcyclustijd is:

$$
T_{\text {tarn ep }}=-\frac{\mathbb{N}_{\text {tot }}}{\mathbb{N}_{\text {cycl }}} \times T_{c}
$$

of

$$
\mathrm{T}_{\mathrm{C}}=\text { groeifractie } \times \mathrm{T}_{\text {turn ep }}
$$

echter,

$$
-\frac{T_{T}}{T_{S}}=-\frac{\mathbb{N}_{C Y C 1}}{\mathbb{N}_{S}}
$$


Substitutie van (5) en (1) in (4) geeft:

$$
T_{\text {turm }} \mathrm{ep}=-\frac{\mathrm{T}}{\mathrm{S}}-\mathrm{S}-\mathrm{S} 100
$$

In plats van uit te gaan van de eenvoudige formule

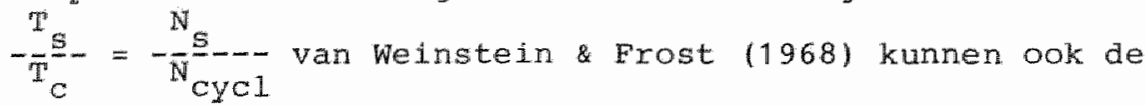
meer ingew 1 kkelde formules wan Duffill et al. (1976) worden gebruikt. De gedachtengang verandert hierdoor echter niet wezeniljk.

Wanneer de Ts bekend is kan de turnovertija van de levende epldermis berekend worden uit het $s$ van het DNA histogram. Deze afleidingen gelden echter alleen als ex sprake is van eer "steady state" conditie en als de cellen at random zijn verdeeld over de celcyclus. Het is duidelijk dat deze vergelijkingen met terughoudendheid moeten worden gernterpreteerd.

De in bovenbeschreven afleidingen gebruikte symbolen worden als volgt gedefinieerd:

$\begin{aligned} \mathbb{N}_{\text {tot }}= & \text { aantal cellen in de levende epidermis; } \\ = & \text { aantal cellen met een DNA hoeveelheid tussen } 2 \mathrm{c} \\ & \text { en } 4 \mathrm{C} \text { DNA; } \\ \mathbb{S}_{\mathrm{S}}= & \text { aantal cellen dat de celcyclus daadwerkelijk door- } \\ & \text { loopt; }\end{aligned}$

$\mathrm{S}=$ cellen met DNA warden tussen $2 \mathrm{c}$ en $4 \mathrm{c}$, uitgedrukt als percentage van het totale aantal cellen, zoals met de flowcytometer wordt gemeten;

s $S^{\prime}=$ cellen met DNA waarden tussen $2 \mathrm{c}$ en $4 \mathrm{c}$, uitgedrukt als percentage van de werkelijk prolifexerende populatie;

$\mathrm{T}_{\mathrm{s}}=$ duur van de siase;

$\mathrm{T}_{\mathrm{C}} \quad=$ celcyclustijd;

'Turn ep $=$ turnovertijd van de levende epidermis:

G. E. = groeifractie. 


\subsection{REEERENTIES.}

Baisch, H. \& Linden, W.A. : Different mathematical models for pulse-cytophotometric evaluations applied to asynchronous and partially synchronized cell populations. In: Pulsecytophotometry I, C.A.M. Haanen, H.E.P. Hillen \& J.M.C. Wessels, European Press Medikon, Ghent, pag. 61-67,1975.

Baisch, H., Göhde, W. \& Linden, W.A.: Mathematical analysis of ICP-data to determine the fraction of celis in the various phases of the cell cycle. In: Pulse-cytophotometry I, C.A.M. Haanen, H.F.P. Hillen \& J.M.C. Wessels, European Press Medikon, Ghent, pag. 68-76,1975.

Bauer, F.W. \& De Grood, R.M.: Improved technique for epidermal cell cycle analysis. Br. J. Derm.,95:565-567, 1976.

Beck, H.P.: Effect of pepsin pretreatement on pulse-cytophotometric DNA histograms. Cell Tussue Kinet., 10:265-268, 1977 .

Dean, P.N. \& Jett, J.H.: Mathematical analysis of DNA distributions derived from flow microfluorometry. J. Cell. Bio1. ,60:523-530,1974.

Duffill, M., Wright, N. \& Shuster, S.: The cell proliferation kinetics of psoriasis examined bij three in vivo techniques. Br. J. Derm.,94:355-362,1976.

Göhde, W.: Zellzyklusanalysen mit dem Impulscytophotometer. Der Einfluss chemischer und physikalischer Noxen auf die Proliferationskinetik von Tumorzellen. Habilitationsschrift, Medizinische Fakultät, Münster, 1973.

Göhde, W., Schumann, J. \& Fruh, J.: Coincidence eliminating device for pulse-cytophotometry. In: Pulse-cytophotometry part II, W. Göhde, J. Schumann \& Th. Büchner, European press, Medikon, Ghent, pag. 79-85, 1976.

Halprin, K.M.: Epidermal "turnover time" - A re-examination Br. J. Derm. , 86:14-19,1972.

Hentzer, B. \& Kobayasi, T.: Dissociation of human adult ep1dermal celis by disulfide-reducing agents and subsequent trypsinization. Acta Dermatovener. (Stockholm) 56:19-25, 1976 .

Hillen, H.F.P.: Pulse cytophometry in acute leukemia. Proefschxift, Nijmegien, 1975 .

Kobayasi, T., Hentzer, B. \& Asboe-Hansen, G.: Degradation of dermal fibrillar structures: effects of collagenase, elastase, dithioerythrol and citrate. Acta Dermatovener. (stockholm), $57: 379-387,1977$. 
Kraemer, P.M., Deaven, L.L., Crissman, H.A. \& Van Dilla, M.A.: DNA-constancy despite variability of chromosome number. In: E.J. Du Praw, Advances in Cell and Molecular Biology, Academic Press, New York, vol. 2, pag. 47-107, 1972.

Vendrely, C.: Cytophotometry and histochemistry of the cell cycle. In: $\mathbb{R}$. Baserga, The cell cycle and cancer, Dekker, New York, pag. 227-268,1971.

Welnstein, G.D. \& Frost, P.: Abnormal cell proliferation in psoriasis. J. Invest. Derm., 50:254-259,1968.

Welnstein, G.D. \& Housman, R.: Interrelationship of epidermal proliferative and differentiated cell kinetics. J. Invest. Derm. $58: 265-272,1972$. 
HOOFDSTUK 4

DNA DISTRIBUTIE IN NORMALE HUMANE EPIDERMIS.
4.1 .
Inleiding
4.2 .
Materiaal en methode
4.3.
Resultaten
4.3.1. Normaal waarden
4.3.2. Invloed van het geslacht
4.3.3. Invloed van de leeftijd
4.3.4. Invloed van het seizoen
4.3.5. Invloed van de plaats op het lichaam
4. 4 .
Discussie
4. 5 .
Referenties 


\subsection{INLEIDING.}

Voor de invoering van de flowcytometrie werd het onderzoek nar de spreiding wan de diverse celkinetische parameters en de daaruit berekende celcyclustijden van de normale epidermis bemoeilijkt door de arbeidsintensiviteit van de te verrichten onderzoekingen. Ook de statistische betrouwbaarheid liet, gezien het vaak kleine aantal onderzochte cellen en patienten, te wensen over. Vergelijking van de in de literatuur vermelde gegevens brengt dan ook aanzienlijke tegenstellingen aan het licht. Flowcytometrle van een met propldium jodide gekleurde epidermiscelsuspensie makt het mogelijk informatie over de verdeling van het DNA gehalte van grote aantallen individuele cellen te verkrijgen binnen korte tijd.

Bovendien geeft het meten van een groot aantal (10 ${ }^{5}$ ) cellen een statistische betrouwbaarheid die met geen van de andere beschikbare methoden is te bereiken. Omdat het afnemen van de huidmonsters gemakkelijk en onschulaig is, kunnen vele biopsieën worden werkregen.

De percentages cellen in de diverse fasen van de celcyclus kunnen uit de histogrammen worden berekend, omdat cellen in de $G_{1}$, $S$ en $G_{2} M$ fase worden gekenmerkt door een karakteristieke hoeveelheid DNA.

Het doel van dit hoofdstuk is statistisch meer betrouwbare informatie over de DNA verdelingen van de cellen van de normale humane epidermis te verkijgen.

De invloed van het geslacht en de leeftijd op deze parameters wordt onderzocht. Eventuele verschillen in DNA distributie tussen zomer en winter zijn bekeken. De verschillen tussen diverse plaatsen op het lichaam zijn onderzocht teneinde na te gaan of bij de beoordeling van een histogram van cellen afkomstig ult een psorlasislaesie rekentng moet worden gehouden met de plats van afname. Uit de met de flowcytometer verkregen gegevens is de turnovertija van het gehele levende epitheel en de celcyclustijd van de basale cellen berekend. De gevonden resultaten zijn met de in de literatuur opgegeven warden vergeleken.

\subsection{MATERIAAI EN METHODE.}

De huidbiopsieën zijn gemomen van normal uitziende huid van vrijwilligers zonder huldziekten. Bij allen was de familieanamnese negatief voor psorilasis. De monsters zijn genornen 
van de rug, armen, benen en knleën. Afname en bewerking van de monsters geschiledde als beschreven in 3.3. en 3.4. . Het tijdstlp van afname was tussen 9.00-10.00 uur a.m. teneinde be invloeding door een mogelijke "diurnal variation" uit te sluten. De Eluorescentie van het aan propidium jodide gebonden DNA is gemeten met behulp van de Impuls cytophotometex (I.C.P. 11, Phywe, Göttingen, BRD) (cf. 3.2.). Analyse van de histogrammen vond plaats met behulp van een programma ontwikkela door De Jongh \& Boezeman (Cf. 3.5.) dat een modificatie is van het door Balsch \& Iinden (1975) beschreven planimetrdsche model. War aangegeven zijn de waarden gecorrigeerd voor de coincidentie (cf. 3.5.3.). De statistische analyse geschiedde met Statistlcal Package for the Social Sclences (S.P.S.S.) subprogramma's (N.e, 1975; U.R.C.,1979).

\section{3. RESULTATEN.}

\section{3. 1. NORMAAL WAARDEN .}

De gemidaelde percentages diploide, tetraploide en interploide cellen, alsmede de ratio $\mathrm{s} / \mathrm{G}_{2} \mathrm{M}$, voor normale humane epldermis zijn weergegeven in tabel 4.1 .

Tabe 1.1 .

\begin{tabular}{cccc}
\hline \multicolumn{5}{c}{ Normale epidermis } & $\mathrm{n}=137$. \\
\hline \multicolumn{1}{c}{$\mathrm{S}$} & $\mathrm{S}$ & $\mathrm{G}_{2} \mathrm{M}$ & $\mathrm{S} / \mathrm{G}_{2} \mathrm{M}$ \\
\hline $\mathrm{A} 96,2 \pm 1,0$ & $2,6 \pm 0,8$ & $1,2 \pm 0,5$ & $2,5 \pm 1,1$ \\
B 97,4 & 1,8 & 0,9 & - \\
\hline
\end{tabular}

Tabe1. 4.1.: Analyse van de DNA verdelingen in de normale humane epidermis bij 137 huidmonsters. A: gebaseerd op de planimetrische methode. B: gecorrigeerd voor de coincidentie (gemiddelde pulse rate 250 cellen per seconde).

\subsubsection{INULOED VAN HET GESLACHT.}

Tussen mannen en vrouwen bestaan geen slgnificante verschillen in DNA distributie in normale epidermiscellen (tabel 4 . 2.). 
Tabe1 4.2 .

\begin{tabular}{lccccr}
\hline & $\mathrm{n}$ & $2 \mathrm{c}$ & $\mathrm{s}$ & $\mathrm{G}_{2} \mathrm{M}$ & $\mathrm{S} / \mathrm{G}_{2} \mathrm{M}$ \\
\hline Man & 99 & 96,3 & 2,6 & 1,2 & 2,5 \\
Vrouw & 38 & 96,1 & 2,6 & 1,3 & 2,4 \\
\hline Signific. & $\mathrm{p}=$ & 478 & 998 & 168 & 408 \\
\hline
\end{tabular}

Tabel 4.2.: Invloed van het geslacht van de persoon op de DNA verdelingen in de normale humane epldermis.

4.3.3. INVLOED VAN DE LEEFTIJD.

Teneinde de invloed van het jaargetijde (zie 4.3.4.) uit te sluiten zijn alleen metingen die in juni-juli zijn verricht geselecteerd voor de analyse. Er is tevens zorg voor gedragen dat in de leeftijdsgroepen een uniforme verdeling wat betreft de plaats van afname bestaat.

Figuur 4.1. toont de met behulp van de PDP $11 / 45$ computer verkregen scatter diagrammen met daarin getrokken de regressielijnen van de 4 onderzochte parameters tegen de leeftijd.

Figuur 4.1 .
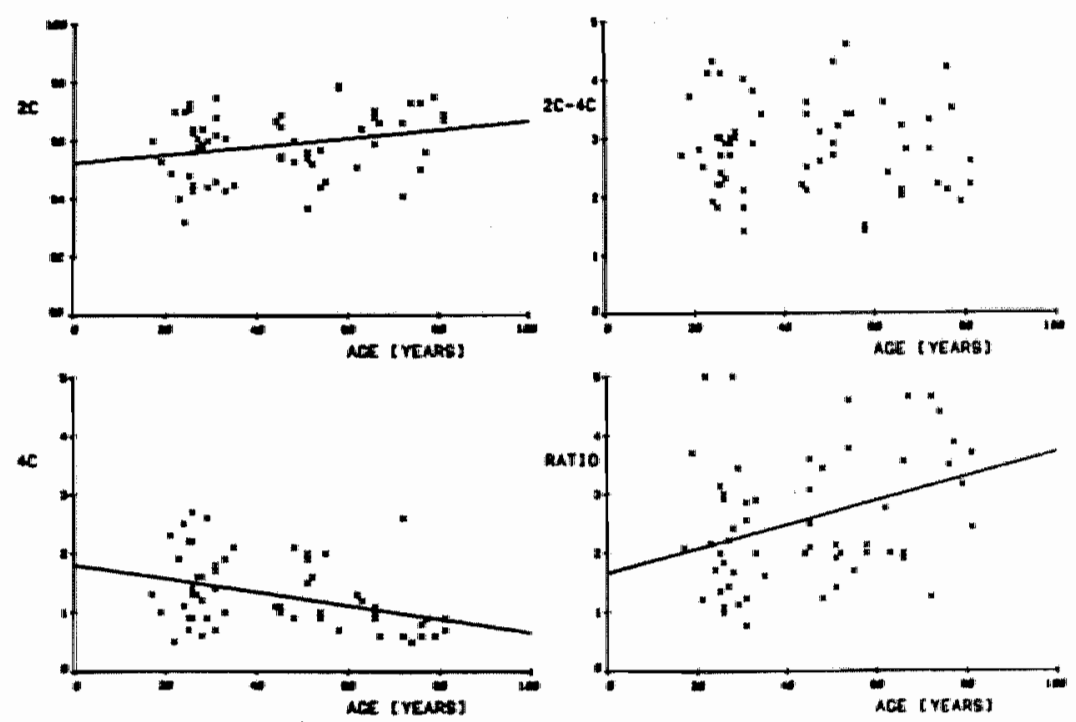

Figuur 4.1.: De met behulp van de PDP $11 / 45$ computer verkregen scatter diagrammen en de regressielijnen van de aiverse parameters tegen de leeftijd. 
Tabe1 4.3. geeft de 1nvloed van de leeftijd van de persoon weex op de gemeten percentages. De percentages $2 \mathrm{c}$ en $\mathrm{G}_{2} \mathrm{M}$ zijn afhankelijk van de leeftijd. Blj het ouder worden neemt de $2 \mathrm{c}$ fractie met $0,014 \%$ per jaar toe. Het percentage $G_{2} M$ daalt met 0,011 per jaar. Het percentage $S$ is onafhankelijk van de leeftijd. ook de ratio $S / G_{2} M$ verandert significant bij het ouder worden. Per jaar stijgt deze ratio met 0,02 .

Tabe 1.3.

\begin{tabular}{lccc}
\hline $\begin{array}{c}\text { Toename } \\
\text { per jaar }\end{array}$ & $\begin{array}{c}\text { snijpunt } \\
\text { met Y-as }\end{array}$ & $\begin{array}{c}\text { signifi- } \\
\text { cantie }\end{array}$ \\
\hline $2 \mathrm{c}$ & 0,014 & 95,2 & $\mathrm{p}=3,08$ \\
$\mathrm{~S}$ & - & 2,9 & $\mathrm{p}=30,08$ \\
$\mathrm{G}_{2 M}$ & $-0,011$ & 1,8 & $\mathrm{p}=0,28$ \\
$\mathrm{~S} / \mathrm{G}_{2 M}$ & 0,02 & 1,7 & $\mathrm{p}=0,38$
\end{tabular}

Tabel 4.3.: De invloed van de leeftijd op de DNA verdelingen in de normale epidermis. De veranderingen in procenten per jaar veroudering voor de diverse Eracties. Snijpunt met de Y-as is leeftijd = 0 jaar.

4.3.4. INVLOED VAN HET "SEIZOEN".

De diverse percentages cellen in de verschillende fasen van de celcyclus van huidmonsters genomen in juni-juli versus november-december zijn weergegeven in tabel 4.4. Bij de analyse is zorg gedragen voor een uniforme verdeling wat betreft de leeftijdsverdeling en de plats van afname. De warden voor $2 \mathrm{c}, \mathrm{S}$ en $\mathrm{G}_{2} \mathrm{M}$ verschilien significant ( $\mathrm{p} \leqslant 5 \%$ ). De ratio $s / G_{2} M$ verandert niet met het "seizoen".

Thabe 1.4 .4

\begin{tabular}{lccc}
\hline & juni-juli & $\begin{array}{c}\text { november- } \\
\text { december }\end{array}$ & $\begin{array}{c}\text { signifi- } \\
\text { cantie }\end{array}$ \\
\hline $2 \mathrm{C}$ & 95,9 & 96,5 & 0,18 \\
$\mathrm{~S}$ & 2,8 & 2,4 & 0,18 \\
$\mathrm{G}_{2} \mathrm{M}$ & 1,3 & 1,1 & 3.8 \\
$\mathrm{~S} / \mathrm{G}_{2} \mathrm{M}$ & 2,6 & 2,4 & 40 \\
& $\mathrm{~N}=60$ & $N=77$ & \\
\hline
\end{tabular}

Tabel 4.4: De gemeten DNA verdelingen in celsuspensies van normale epidermis afgenomen in juni-jult en in november-december. 
Onderstaande tabel 4.5. geeft de DNA verdelingen weer voor de normale epidermis op verschillende platsen op het lichaam. Ook hier zijn, teneinde "seizoensinvloeden" uit te sluiten alleen metingen die in de periode juni-juli zijn verricht gebruikt voor de analyse. De verkregen waarden zijn gevonden na lineaire correctie voor leeftijdsinvioeden.

Tabe 14.5 .

\begin{tabular}{l} 
r \\
\hline
\end{tabular}

Tabe1 4.6.: Overzicht wan de significantie ( $\$ 5$ ) van de verschillen tussen enkele plaatsen op het 1icham voor de fracties van de celcyclus en voor de ratio $\mathrm{S} / \mathrm{G}_{2} \mathrm{M}$. - = significantie meer dan $5 \% ;+=$ significantie minder dan $5 \%$. 
Gegevens over cytofotometrische onderzoekingen van normale en pathologisch veranderde humane epidermis zijin zeldzaam in de Ilteratuur. Grove et al. (1976) voerden statische cytofotometrische onderzoekingen uit bij normale en psoriasis eplaermis. Deze procedure is veel langzamer dan de flowcytometrische methode terwijl ook de variatie coëfficient, die de analyse van de DNA verdelingen beinvloedt, veel groter is. De auteurs slaagden er niettemin in, ondanks de moeilijkheden die inherent zijn an de methode (Würthner et 1. 1972), verschillen in DNA verdelingen tussen normale epidermis en psoriasis aan te tonen.

Haag et al. (9975) bestudeerden het DNA gehalte in nuclei van een suspensie van epidermiscellen. De auteurs geven echter geen nadere analyse van de verkregen histogrammen. Het aantal onderzochte cellen was bovendien beperkt.

Flowcytometrie, door Bauex et al. (1975) geintroduceerd in de dermatologie en in dit proefschrlft nader uitgewerkt, maakt het mogelijk schattingen van het gehalte aan DNA in de kernen van een groot aantal epldermiscelien te maken binnen korte tijd: meer dan $10^{5}$ cellen kunnen binnen anderhalf uur na afname worden gemeten.

Het DNA histogram weersplegelt de percentages cellen in de verschillende fasen van de celcyclus. De hier vermelde flowcytometrische metingen zijn uitgevoerd op epitheliale celsuspensies van de gehele levende epldermis. Niet alleen cellen in de $G$ fase van de celcyclus hebben een $2 \mathrm{c}$ DNA hoeveelheid. Ook een deel van de $G_{0}$ cellen (Gelfant, 1976) en de gedifferentieerde cellen in het stratum spinosum en stratum granulosum hebben een $2 \mathrm{c}$ hoeveelheid DNA in hun kernen. Het is derhalve niet juist cellen met een $2 \mathrm{c}$ hoeveelheld DNA als $G_{1}$ cellen te beschouwen.

Tevens hebben we bij deze studie aangenomen dat we alleen keratinocyten in de suspensie hebben. Dit is uiteraard niet war. Andere celtypen zijn eveneens aanwezig maar in relatief kleine aantalien zodat, zelfs als zij een zeer afwijkende klnetlek zouden hebben, hun invloed op de gevonden warden verwarloosd kan worden.

Cellen in de $G_{2}$ en de $M$ fase, die beide $4 \mathrm{c}$ DNA bevatten, kunnem met de flowcytometer niet van elkaar worden geschelden.

Alle DNA verdelingen zijn geanalyseerd met een mathematisch model, warin geen correctie voor de coincidentie is opgeromen. De bljdrage van de coIncidentie aan het percentage $S$ en $G_{2} M$ is afhankelijk van de signaalwijdte de pulse rate. omat de ICP apparatuur geen mogelijkheid heeft de signaalwijate te meten, hebben we een correctie voor de corncidentile gemakt op basis van calibratie curven.

De flowcytometrische metingen in deze studie zijn uitgevoerd op celsuspensies van de gehele levende epidermis. Het wergegeven percentage $s$ heeft derhalve betrekking op alle levende epidermiscelien. Door het gevonden percentage s te 
vermeniguruldigen met een factor 3,2, zijnde de ratio $\mathrm{N}$ totaal / $\mathrm{N}$ cycl. (Halprin, 1972 ) wordt het aantal cellen in de $S$ fase gerelateerd aan de proliferatieve celpopulatie gevonden. Bij vergelijking van het op deze wijze door ons gevonden percentage $S$, biljkt dit percentage goed overeen te stemmen met de gemiddelde warde van een aantal 1abe 1ling indices zoals deze in de literatur worden vermela (Potten, 1975).

De enige ons bekende studie aangaande DNA flowcytometrie van normale humane epidermis geeft waarden voor $S$ en $G_{2} M$ fractie $\left(S: 3,0 \# 0,6 ; G_{2} M: 1,1 \pm 0,1\right)$ die overeenstemmen met de hiex vermelde. In deze studie zijn echter 14 monsters van én patient gemeten (Frentz et all.,1980).

Celcyclustijden (TC) en turnovertijden (Tturn ep.) kumnen niet rechtstreeks met de onderhavige methode worden bepalid. De hier verrichte metingen kunnen slechts relatieve celcyclustijden geven. Een schatting kan echter worden gemaakt als $\mathbb{T}_{s}$ bekend is,

$$
T_{\text {turn ep }}=-\frac{T}{8}-\times 100 \quad(\text { Cf. } 3.6 .3 .)
$$

Indien we aannemen dat $T_{S}=8$ uur (gemiddelde waarde uit de literatuur, celfant, $1976)$.

$$
\begin{aligned}
T_{\text {turn ep }}=-\frac{8}{1}, \overline{8}-\times 100 & =444 \text { uur } \\
& =18,5 \text { dagen }
\end{aligned}
$$

Deze waarden komt overeen met turnovertijden zoals deze zijn berekend uit onderzoekingen met gelabelde aminozuren (Rothberg et al.,1961).

De gemiddelde celcyclustijd bedraagt:

$$
\begin{aligned}
& \mathbb{T}_{C}=\text { G.F.X } \mathbb{T}_{\text {turn ep }} \quad(\mathrm{c} f \cdot 3 \cdot 6 \cdot 3 .) \\
& \begin{aligned}
\mathbb{T}_{C}=-\frac{1}{3}, \frac{1}{2} \times 18,5 & =5,8 \text { dagen } \\
& =139 \text { uur. }
\end{aligned}
\end{aligned}
$$

Uiteraard zijn dit ruwe schattingen. 
In de statistische studies is geen correctie voor de coincidentie aangebracht. Het is niet waarschijniljk dat de coincidentle bijarage aan het percentage $S$ en $G_{2} M$ verschilt in de groepen die worden onderzocht.

In geen van de onderzochte parameters zijn verschilien gevonden tussen de beide geslachten.

Tabel 4.3. toont aan dat er in enkele van de gemeten parameters een leeftijdsathankelijkheid bestaat. Meerdere interpretaties hiervoor zijn mogelijk. Het feit echter dat de ratio $\mathrm{S} / \mathrm{G}_{2} \mathrm{M}$ stijgt blj het ouder worden betekent dat de relatieve duur van de $s$ fase t.o.v. de $G_{2} \mathrm{M}$ fase langer wordt. Bij veroudering treden ex derhalve veranderingen in de celCyClus op.

Tabe1 4.4. Lat zien dat er "selzoens" variaties (strikt genomen, verschillen tussem twee specifieke tijden van het jaarl in het percentage cellen in $S$ en $G_{2} M$ fase bestaan. De ratio $\mathrm{S} / \mathrm{G}_{2} \mathrm{M}$ verandert niet. Op dit moment kunnen we slechts speculeren over de betekenis van deze verschillen, omat we te weinig gegevens hebben. Een mogelijke verklaring kan zijn dat de groelfractie in de zomer hoger is dan in de winter; dat de duur van zowel de $S$ als de $G_{2} M$ fase in de zomer verlengd is of dat de-G fase verkort is bij gelijkblijvende $S$ en $G_{2} M$ Ease.

Kleine verschillen in DNA verdeling bestaan er tussen de diverse plaatsen op het lichaam. In het bijzonder bij het vergelijken van arm met been komen er statistisch significante verschililen aan het licht in de $2 \mathrm{c}$ warde (hoger in beenl en $G_{2} M$ warae (lager in been). Het aantal DNA synthetiserende cellen is echter niet afhankelijk van de plaats. De knie, een plaats die voortdurend blootstat a an mecha-i. nische prikkeling en tevens een van de predilectieplaatsen voor psoriasis, verschilt in de hier gemeten parameters niet valn arm, been of rug. De gevonden plaatsverschilien zijn echter zo gering dat bij afname van monsters uit psoriasislaesies geen correctie voor de afnameplaats behoeft te worden gemaakt.

Bovenstaande meetresultaten tonen an dat een aantal variabelen de gegevens beinvloeden. Dit kan enkele van de tegenstrijdige gegevens, die men in de literatur kan vinden aangaande celkinetische parameters van normale humane epidermis, verklaren. Op grond van de snelheid en het gemak waarmoe de resultaten kunnen worden verkregen is flowcytometrie, ondanks de beperkingen van de hier gebrulkte apparatuur, een geschikte methode gebleken om deze variabelen te bestuderen. 
4. 5. REFERENTIES .

Baisch, H. I Inden, W.A.: Different mathematical models for pulse cytophotometric evaluations applied to asynchronous and partially synchronized cell populations. In * PulseCytophotometry, Part I, pp 68-76, Eds. Haanen, Hilien and Wessels, European Press Medikon, Ghent, Belgium), 1975.

Bauer, F.W. \& De Grood, R.M. : Impulse cytophotometry in psoriasis. Br. J. Derm.,93:225-227,1975.

Frentz, G., Moller, U. Chxistensen, I.: DNA flow cytometry on human epidermis: I. Methodological stuaies on nomal skin. J. Invest. Derm., 74:119-121,1980.

Gelfant, S.: The cell cycle in psoriasis: a reappraisal. Bx. J. Derm., 95:577-590,1976.

Grove, G.I., Anderton, R.L. \& Smith, J.G.: Cytophotometric studies of epidermal proliferation in psoriatic and normal skin. J. Invest. Derm., 66:326-238,1976.

Haag, D., Tschahargane, C. \& Ehemann, V.: Isolation of single cell nuclei from human epidermis for cytophotometric DNA measurements. Arch. Derm. Res.,253:301-310,1975.

Halprin, K.M. : Epidermal "turnover time" - A re-examination. Br. J. Derm. ,86:14-19,1972.

Nie, N.H.: Statistical Package for the Social Sciences, McGraw-Hi11, London, 1975.

Potten, C.S.: Epidermal cell production rates. J. Invest. Derm. , 65:488-500,1975.

Rothberg, S., Crounse, R.G. \& Lee, J.L.: Glycine-C ${ }^{14}$ incor- $^{-}$ poration into the proteins of normal stratum corneum and the abnormal stratum corneum of psoriasis. J. Invest. Derm.,37: $497-505,1961$.

U.R.C. (Universitair Reken Centrum) Nijmegen: Release 7.02 or I.B.M. $370 / 158 ., 1979$.

Wurthner, K., Sachs, H. \& Bahnsen, J.: Zum Problem der Kermanschnitte bei dex zytophotometrie an histologischen Praparaten. Histochemie, $32: 261-270,1972$. 
HOOFDSTUK 5

DNA DISTRIBUTIE IN LAESIES EN KLINISCH NIET AANGETASTE EPIDERMIS VAN PSORIASISPATIENTEN.

5.1. Inleiding

5.2. Material en methode

5.3. Resultaten

5.3.1. Psoriasis vulgarlis

5.3.2. Interindividuele en intraindiwiduele variantie

5.3.3. Intrallaesionale variantie

5.3.4. Onrustige psoriasis

5.3.5. Psoriasis pustulosa

5.3.6. KIInisch niet aangetaste epidermis bij psoriasis

5.4. Discussie

5.5. Referenties 
DNA DISTRIBUTIES IN LAESIES EN KIINISCH NIET AANGETASTE ERIDERMIS VAN PSORIASISPATIENTEN.

5. 1. INIEIDING.

Psoriasis wordt gekenmerkt door een aantal veranderingen in de epldermiscellen. Er is een toename van het totale aantal cellen per eenheid huidoppervlak (Van Scott Ekeit, 1963), van het aantal proliferatieve cellen (Goodwin et al. 1974), van de grootte van de cellen (Fry \& McMinn, 1968), van het celoppervlak (Gommans et al.,1979) en van het aantal mitoseEiguren (cf. 2.5.1.).

Bovendien is men in de literatuur eensgezind van mening, dat de celcyclustijd van een psoriasiscel korter is dan van een normale epidermiscel (cf. 2.9.). De door diverse auteurs gevonden waarden voor labelling index en celcyclustijd verschillen echter aanzienlijk (Gelfant, 1976; Grove, 1979; cf. 2.9.). Over de celkinetiek van de klinisch normale epidermis bij personen met psoriasis zijn de meningen verdeeld. Wohlrab \& Gruneberg (1966) en Weinstein \& Frost (1968) vinden geen verschillen; Hell \& Hodgson (1966), Braun-Falco et al. (1967), Kaidby \& Kurban (1971), Goodwin et al. (1973) vinden daarentegen een toename van de mitotische en labelling indices in de klinisch normale epidermis bij psoriasis vergeleken met normale epidermis.

Alle tot nu toe uitgevoerde studies over de celkinetische aspecten van psoriasiscellen zijn aan statistische beperkingen onderhevig. De vraag werpt zich op of de in de literatuur gevonden verschillen in aantal DNA synthesiserende cellen berusten op methodieke verschillen of dat er sprake is van een grote intra- en interindividuele variabiliteit. Flowcytometrie maket het mogelijk het DNA gehalte van vele individuele cellen bij een groot antal persorien te bepalen.

Het doel van dit hoofdstuk is statistisch meer betrowwbare informatie te verkrijgen over de DNA verdelingen in cellen afkomstig uit psoriasislaesies. Op klinische gronden zijn drie typen psoriasis onderscheiden: de chronisch verlopende psorlasis vulgaris, waarbij de lavies vrijwel lnert zijn, de onrustige psoriasis en de zeer heftig verlopende psoriasis pustulosa.

De intralaesionale verschillen in DNA verdeling zijn bepaald teneinde na te gaan of $b i j$ het vergelijken van de interlaesionale verschilien rekening moet worden gehouden met de plaats van afname in de laesie.

Op grond van het klinisch aspect, het natuurlijk beloop en de reactie op therapie rijst de vraag of elke patient $z i j n$ "eigen" psorliasis heeft. Teneinde deze hypothese te toetsen zijn de verschilien tussen diverse laesies van hetzelfae type psoriasis bij dezelfde persoon en de verschillen tus- 
sen personen met hetzelfde type psoriasis vergeleken.

5. 2. MATERTAAL EN METHODE.

De huidblopten zijn genomen op de in hoofdstuk 3 beschreven wijze uit laesies van patienten met een klinisch manifeste psoriasis vulgaris, die tot minimaal een week voor afname geen theraple hadden ontvangen. Alle biopten zijn in de perlode juni-juli afgenomen.

De spreiding binnen eenzelfde laesie is bepaald door een aantal biopten te nemen langs een rechte lijn door het midden van de afwijking. Afhankelijk van de grootte van de afwijking zijn meerdere monsters uit rand en centrum genomen. Onder rand wordt verstaan de buitenste anderhalve centimeter van de afwijking.

De interlaesionale verschillen bij" eenzelfde persoon zijn bepaald door uit het centrum van een aantal willekeurige, gelijk uitziende psoriasisplekken huidmonsters te nemen. De biopten bij de personen met een $z$ ich snel uitbreidende psoriasis pustulosa zijn gelijktijaig genomen uit de normaal uitziende huid op een plaats waar te verwachten was dat de laesle zou passeren, uit de huld voor het front war reeds veranderingen zlchtbaar waren, uit het front en op een plats achter de voortkruipende rand, waar na een massale afstoting van necrotisch epltheel, een weer min of meer gave huid resteerde.

De proliferatiepatronen van de huidbiopten zijn met de flowcytometer op de in hoofdstuk 3 beschreven wijze bepaald. De statistische verwerking van de aldus verkregen gegevens geschiedde met SSPS subprogramma's (Nie,1975; U.R.C.,1979).

5. 3. RESULTATEN.

5.3.1. PSORIASIS VULGARIS.

De gemiddelde percentages voor de diverse fracties van de celcyclus $z 1 j n$ samengevat in tabel 5.1 . Deze verschilien significant van de overeenkomstige pexcentages voor normale eplarmis ( $\mathrm{P} \leqslant 0.01)$.

Tabe1 5.1. geeft ook de warden gecorrigeerd voor de coincidentie weer.

Vergeleken met normale epidermis is de variatie tussen de individuele specimens groot. Dit kan berusten op meerdere factoren: op verschillen in de laesie zelf, op variatie tussen verschillende laesies bij én persoon en op interindividuele verschilien.

Het aandeel van elk van deze factoren is onderzocht. 


\begin{tabular}{lllll}
\hline & \multicolumn{2}{c}{$\mathrm{S}$} & $\mathrm{G}_{2} \mathrm{M}$ & $\mathrm{S} / \mathrm{G}_{2} \mathrm{M}$ \\
$\mathrm{A}$ & $87,4 \pm 3,4$ & $9,7 \pm 2,6$ & $2,9 \pm 1,4$ & $4,1 \pm 2,2$ \\
\hline
\end{tabular}

Tabel 5.1.: Analyse van de DNA verdelingen in psoriasis vulgaris laesies. A: gebaseerd op de planimetrische methode. B: gecorrigeerd voor de coincidentie (gemiddelde pulse rate 250 cellen per seconde).

5.3.2. INTERINDIVIDUELE EN INTRAINDIVIDUELE VARIANTIE.

Bij de analyse van oorzaken van deze variabiliteit is gebruik gemaakt van de variantie in plaats van de stanaaard deviatie. De variantie voor psoriasis laesies is gebaseerd op een populatie van 94 monsters van 17 personen. De vraag rijst of deze populatie homogeen is t.o.v. de persoon, m. a. W. of de vaxiantie in de subpopulatie biopsieën van eenzelfde patient evengroot als of significant kleiner dan de variantie in de totale populatie is.

Hervoor is een -one way- variantie analyse met factor patient nummer uitgevoerd. De variantie is gescheiden in een inter- en een intraindividuele component (tabel 5.3.).

Tabe 15.3 .

\begin{tabular}{lcccc}
\hline & $2 \mathrm{C} *$ & $\mathrm{~S}^{*}$ & $\mathrm{G}_{2} \mathrm{M}^{*}$ & $\mathrm{~S} / \mathrm{G}_{2} \mathrm{M}^{*}$ \\
$\begin{array}{l}\text { Interindividuele } \\
\text { variantie }\end{array}$ & 6,6 & 4,8 & 2,6 & 3,3 \\
$\begin{array}{l}\text { Intraindividuele } \\
\text { variantie }\end{array}$ & 2,2 & 1,8 & 1,0 & 1,9 \\
Verklaarde variantie & 648 & $61 \%$ & 578 & 398 \\
\hline & $* \mathrm{P} \leqslant 0.01$ & &
\end{tabular}

Tabel 5.3.: Variantie anaylse in inter-en intraindividuele componenten. 
Tussen verschillende plekken van klinisch hetzelfde type psoriasis bij eenzelfde persoon alsook tussen de verschillende patienten bestaan aanzienlijke verschillen. Tabel 5.2. geeft dit 1 llustratief weer.

Tabe1 5.2.

\begin{tabular}{|c|c|c|c|c|c|c|}
\hline Pat. & No & Plaats & $\mathrm{G}_{1}$ & $s$ & $\mathrm{G}_{2} \mathrm{M}$ & Ratio \\
\hline \multirow[t]{7}{*}{ I } & 1 & $\begin{array}{l}\text { I1. boven- } \\
\text { been }\end{array}$ & 82,6 & 14,0 & 3,4 & 4,1 \\
\hline & 2 & $d i j$ & 82,4 & 12,2 & 5,4 & 2,3 \\
\hline & 3 & rug & 84,6 & 11,1 & 4,3 & 2,6 \\
\hline & 4 & rug & 78,4 & 14,7 & 6,8 & 2,2 \\
\hline & 5 & onderarm & 85,7 & 11,6 & 2,7 & 4,3 \\
\hline & 6 & borst & 80,7 & 14,6 & 4,7 & 3,1 \\
\hline & 7 & borst & 81,7 & 13,4 & 4,9 & 2,7 \\
\hline \multirow[t]{7}{*}{ II } & 1 & $d i j$ & 89,1 & 7,8 & 3,1 & 2,5 \\
\hline & 2 & $\mathrm{~d} i j$ & 90,7 & 7,0 & 2,3 & 3,0 \\
\hline & 3 & been & 90,3 & 6,6 & 3,0 & 2,2 \\
\hline & 4 & re.arm & 89,5 & 7,6 & 2,8 & 2,7 \\
\hline & 5 & 1i. arm & 93,6 & 5,3 & 1,1 & 4,8 \\
\hline & 6 & sacrum & 88,9 & 6,8 & 4,2 & 1,6 \\
\hline & 7 & sacrum & 91,5 & 5,6 & 2,9 & 1,9 \\
\hline \multirow[t]{6}{*}{ I I I } & 1 & rug & 90,7 & 7,1 & 3,2 & 2,2 \\
\hline & 2 & been & 87,2 & 10,7 & 2,0 & 5,4 \\
\hline & 3 & buik & 84,0 & 13,0 & 3,0 & 4,3 \\
\hline & 4 & rug & 91,2 & 7,4 & 1,3 & 5,7 \\
\hline & 5 & rug & 88,9 & 8,6 & 2,5 & 3,4 \\
\hline & 6 & rug & 83,5 & 14,1 & 2,3 & 6,1 \\
\hline
\end{tabular}

Tabel 5.2.: Overzicht van de DNA verdelingen in procenten en de ratio $S / G_{2} M$ van een aantal willekeurig gekozen psoriasis vulgaris laesies bij drie personen. De hier weergegeven percentages zijn illustratief voor de verschilien tussen de personen en voor de spreiding die binnen Eén persoon kan bestaan. 
Uit tabel 5.3. kan worden geconcludeerd dat de individuele subpopulaties significant meer homogeen zijn dan de totale populatie. Minimaal $39 \%$ en maximaal 648 van de totale variantie wordt verklaard door interindividuele verschillen. Het aantal biopsieên en de afnameplaats waren niet identiek voor alle patienten. Een - two way- analyse van plats en patient nummer gaf geen significante toename van de verkiaarde variantie.

5.3.3. INTRALAESTONALE VARIANTIE.

Teneinde na te gaan of een psoriasislaesie kinetisch homogeen is zijn in totaal 31 biopsieën gemeten uit het centrum en de rand van 6 psoriasis vulgaris laesies. Voor dit onderzoek zijn de huidmonsters van elk individu genomen uit een enkele laesie. De plaats van de laesie was niet gelijk voor elke patient (tabel 5.4.).

Tabel 5.4

\begin{tabular}{|c|c|c|c|c|c|c|}
\hline \multirow{2}{*}{$\begin{array}{l}\text { Patient } \\
\text { no }\end{array}$} & \multicolumn{3}{|c|}{ rand } & \multicolumn{3}{|c|}{ centrum } \\
\hline & been & rug & abdomen & been & rug & abdomen \\
\hline 1 & & 2 & & & 1 & \\
\hline 2 & & 2 & & & 1 & \\
\hline 3 & & & 4 & & & 3 \\
\hline 4 & & 4 & & & 5 & \\
\hline 5 & 2 & & & 3 & & \\
\hline 6 & & & 2 & & & 2 \\
\hline totad 1 & 2 & 8 & 6 & 3 & 7 & 5 \\
\hline
\end{tabular}

Tabel 5.4.: Samenwatting van de biopsleplaatsen van elke patient.

De significantie van de mogelijke verschillen van de gemiddelde waarde van elke patient tussen rand en centrum van de laesie is bepaald met de student's t-test ervan ultgaande dat de monsters waren gepaard aan de patient.

Tabel 5.5. toont dat er geen significant verschil in de hier onderzochte parameters is tussen rand en centrum van psoriasisilaesies. 
verschil centrum-rand

\begin{tabular}{|c|c|c|c|c|c|c|c|c|}
\hline \multirow{2}{*}{$n$} & \multicolumn{2}{|c|}{$2 c^{*}$} & \multicolumn{2}{|c|}{$s^{*}$} & \multicolumn{2}{|c|}{$\mathrm{G}_{2} \mathrm{M}^{*}$} & \multicolumn{2}{|c|}{$S / G_{2} M^{*}$} \\
\hline & gemid. & s..d. & gemid. & s.d. & gemid. & s.d. & gemid. & s.d. \\
\hline 6 & 0,04 & 3,3 & $-0,61$ & 2,8 & 0,58 & 1,0 & $-0,42$ & 1,5 \\
\hline
\end{tabular}

Tabel 5.5.: Student's t-test op het verschil in gepaarde waarnemingen van de gemiddelde waarden van centrum en rand van psoriasislaesies bij 6 patienten.

5.3.4. ONRUSTIGE PSORIASIS.

De DNA verdelingen in celsuspensies afkomstig van personen met een onrustige psoriasis geven een lichte maar duidelijk significante verhoging van het percentage $s$ te zien. Het percentage $G_{2} M$ en de ratio $S / G_{2} M$ zijn niet significant verschillend van de overeenkomstige parameters van psoriasis vulgaris laesies (tabel 5.6.).

Tabe1 5.6 .

$\mathrm{n} 2 \mathrm{~s} \quad \mathrm{G}_{2} \mathrm{M} \quad \mathrm{s} / \mathrm{G}_{2} \mathrm{M}$

Onrustige

psoriasis

$1585,5 \pm 1,3 \quad 11,8 \pm 1,12,7 \pm 0,85,0 \pm 2,5$

Psoriasis

vulgaris

$9487,4 \pm 3,4 \quad 9,7 \pm 2,5 \quad 2,9 \pm 1,44,1 \pm 2,2$

Signifi-

cantie

$$
p=48 \quad p=0,28 \quad p=568 \quad p=148
$$

Tabel 5.6.: Vergelijking van de analyses van de DNA verdeIingen van celsuspensies afkomstig uit laesies van onrustige psoriasis en van psoriasis vulgaris. 
Het klinisch beeld bij personen met een psoriasis pustulosa is van patient tot patient verschillend. De laesies lopen als het waré als een golf in enkele dagen tijd over vaak grote gebieden van het lichaam.

$\mathbb{T}^{\text {abel }} 5.7$. geeft een overzicht van de DNA distributie in de klinisch normale huld en de angetaste huid resp. voor, in en achter het voortschrijdend front van de laesie.

Tabe1 5.7 .

\begin{tabular}{|c|c|c|c|c|c|}
\hline Pat. no. & & $2 c$ & $s$ & $\mathrm{G}_{2} \mathrm{M}$ & $S / G_{2} M$ \\
\hline \multirow[t]{4}{*}{$\mathrm{I}$} & Normale huid & 94,0 & 3,3 & 2,7 & 1,2 \\
\hline & Voor het front & 83,7 & 10,2 & 6,0 & 1,7 \\
\hline & Front & 76,3 & 17,3 & 6,4 & 2,7 \\
\hline & Achter het front & 90,4 & 6.7 & 2,8 & 2,4 \\
\hline \multicolumn{6}{|c|}{ 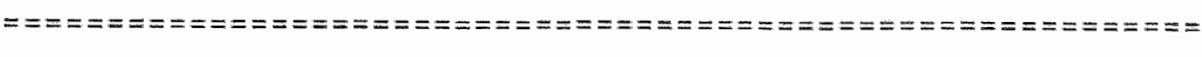 } \\
\hline \multirow[t]{4}{*}{ II } & Normale huid & 92,7 & 4,9 & 2,4 & 2,0 \\
\hline & Voor het Eront & 87,3 & 9,6 & 3,1 & 3,1 \\
\hline & Front & 76,6 & 18,7 & 4,6 & 4,1 \\
\hline & Achter het front & 92,1 & 5,7 & 2,2 & 2,6 \\
\hline \multicolumn{6}{|c|}{ 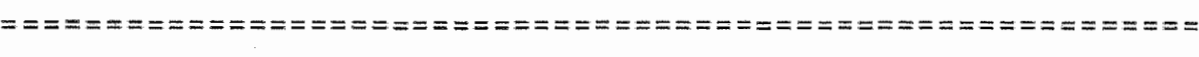 } \\
\hline \multirow[t]{4}{*}{ III } & Normale huid & 94,0 & 4,1 & 1,9 & 2,2 \\
\hline & voor het front & 83,9 & 13,5 & 2,6 & 5,2 \\
\hline & Front & 79,4 & 18,2 & 2,5 & 7,3 \\
\hline & Achter het front & 90,6 & 7,5 & 1,9 & 3,9 \\
\hline
\end{tabular}

Tabel 5.7.: Analyse van de DNA verdelingen in de klindsch normale huid en resp. vó̋r, in en achter de rand van de zich uitbreidende psoriasils pustulosa laesie.

5.3.6. KLINISCH NIET AANGETASTE EPIDERMIS BIJ PERSONEN MET PSORIASIS.

De gevonden percentages voor $20, S$ en $G_{2} M$, alsmede de ratio $S / G_{2} M$ zijn weergegeven in tabel 5.8. In deze tabel zijn ook de warden na correctie voor de coincidentie vermeld. De gevonden waarden verschillen significant van de waarden voor normale epidermis $(p \leqslant 0,01)$. De ratio vertoont geen signigicant verschil (tabe1 5.9.$)$. 
Tabe1 5.8 .

Klinisch niet aangetaste epidermis

$n=47$

$2 c$

s

$\mathrm{G}_{2} \mathrm{M}$

$\mathrm{S} / \mathrm{G}_{2} \mathrm{M}$

A $\quad 94,5 \pm 2,0$

$3,8 \pm 1,4$

$1,8 \pm 0,8$

$2,3 \pm 0,8$

B 95,4

3., 1

1,5

Tabel 5.8. : Analyse van de DNA verdelingen in klinisch niet aangetaste psoriasis epidermis bij 47 huldmonsters. A: gebaseerd op de planimetrische methode. B: gecorrigeerd voor de coIncidentie (gemidalelde pulse rate 250 cellen per seconde).

Tabe1 5.9 .

n.

$2 c$

$S$

$\mathrm{G}_{2} \mathrm{M}$

$S / G_{2} M$

Normale epidermis

60

95,9

2,8

1,3

2,6

KIIn. normale epidermis bij psortasis 47

$\begin{array}{ll}94,5 & 3,8 \\ 0,18 & 0,18\end{array}$

1,8

2,3

significantie $p$

0,18

0,18

18 웅

Tabe1 5.9.: Vergelijking van de DNA verdelingen in normale en niet angetaste epidermis bij psoriasis.

In tabel 5.10. worden de gemeten gemiddelde warden voor de diverse fracties van de celcyclus weergegeven voor normale epldermis, klinisch niet aangetaste epidermis bij psoriasis en voor psoriasis vulgaris laesies. 
Tabe1 5.10 .

\begin{tabular}{lccc}
\hline & $\begin{array}{c}\text { normale } \\
\text { epidermis } \\
\mathrm{n}=60\end{array}$ & $\begin{array}{c}\text { niet aangetaste } \\
\text { epidermis } \\
\mathrm{n}=47\end{array}$ & $\begin{array}{c}\text { psoriasis } \\
\text { laesie } \\
\mathrm{n}=94\end{array}$ \\
\hline $2 \mathrm{c}$ & $95,9 \pm 1,1$ & $94,5 \pm 2,0$ & $87,4 \pm 3,4$ \\
$\mathrm{~S}$ & $2,7 \pm 0,8$ & $3,8 \pm 1,4$ & $9,7 \pm 2,5$ \\
$\mathrm{G}_{2} \mathrm{M}$ & $1,3 \pm 0,6$ & $1,8 \pm 0,8$ & $2,9 \pm 1,4$ \\
$\mathrm{~S} / \mathrm{G}_{2} \mathrm{M}$ & $2,6 \pm 1,1$ & $2,3 \pm 0,8$ & $4,1 \pm 2,2$ \\
\hline
\end{tabular}

Tabel 5.10: Overzicht van de analyses van de DNA verdelingen in procenten van epidermiscellen uit normale epidermis, niet aangetaste epidermis bij personen met psoriasis en uit psoriasislaesies.

5. 4. DISCUSSIE.

ook van op bovenbeschreven wijze geprepareerde epidermiscellen uit een psoriasislaesie is het goed mogelijk met behulp van de flowcytometer DNA verdelingen te verkrijgen. De bijarage van de coincidentie aan het percentage $S$ en $\mathrm{G}_{2} \mathrm{M}$ is bij psoriasiscellen relatief geringer dan bij normale epidermiscellen. De anaylse van de $G_{2} M$ plek wordt niet in meerdere mate gestoord door klontjesvorming.

In de DNA verdeling van cellen uit onbehandelde psoriasis vulgaris laesies wordt een toename van het aantal cellen in de $S$ en $G_{2} M$ fase gezien. Omdat deze percentages van cellen in $S$ en $G_{2} M$ betrekking hebben op het totale aantal epidermiscelien en niet op de proliferatieve cellen alleen, kunnen deze percentages niet direct worden vergeleken met labelling indices gevonden bij autoradiografische studies. ook bij deze onderzoeksmethode wordt echter een toename van het $s$ compartiment gevonden bij psoriasis vergeleken met normale epidermis.

Vergelijking van de hiex weergegeven meetresultaten met die in de bestaande $\mathbb{1}$ iteratur is van beperkte waarde gezien de diversitelt van wroegere onderzoeken. Het overzicht van Gelfant (1976) onderstreept dit nogmaals. Het is duidelijk dat een onathankelijke technlek als flowcytometrie van grote waarde kan zijn. De onderhavige bevindingen ondersteunen de autoradiografische bevindingen van Born \& Kalkoff (1969) en Pullmann, Lennartz \& Steigleder (1977) dat de duur van de $S$ fase is verlengd in de psoriasislaesie, ofschoon andere verklaringen mogelijk zijn, b.v. een korter worden van de tijasduur van $\mathrm{G}_{2} \mathrm{M}$.

Bij psoriasis verschuift de ratio $s / G_{2} M$ naar hogere waarden dan bij normale epidermis. De relatief kleine veranderingen 
In deze ratio lijken in strijd te $z$ ijn met de bevindingen van Goodwin, Hamilton Fry (1973) die de ratio gemerkte cellen mitotische cellen bestudeerden. Zij vonden een ratio van 25:1 bij klinische psoriasis, van 190:1 bij niet aangetaste psoriasis epidermis en van 450:1 bij normale epidermis. Bij aanname dat gemerkte cellen cellen in de $S$ fase zijn zou dit betekenen dat de duur van de $s$ fase $z i c h$ t. o.v. mitoseduur verhoudt als 450:1 in normale epidermis. Bif een $S$ fase duur van 8 uur zou de duur van de mitosefase ongeveer 1 minuut bedragen. Het ligt meer voor de hand a an te nemen dat de gemerkte cellen voor een groot deel reflecteren wat is genoemd "metabool DNA", een suggestie die reeds door deze auteurs is gedaan. Flowcytometrie daarentegen meet DNA hoeveelheid en een cel met een DNA hoeveelheid tussen $2 \mathrm{C}$ en $4 \mathrm{C}$ zal daarom warschijnlijk een cel in de $\mathrm{S}$ fase zijin.

Een verder punt dat de duidelijke verschilien kan verklaren is dat tijdens de preparatieprocedure met het proteolytisch enzym pepsine cellen in de mitosefase worden vernletigd (Beck, 1977). Voor trypsine geldt dit mogelijk ook. Het percentage $4 \mathrm{C}$ cellen reflecteert dan meer $G_{2}$ dan $G_{2} M$. Veranderingen in de duur van de mitosefase zullen dan niet worden geregistreerd.

Uit bovenstaande metingen blijkt in de percentages $2 \mathrm{c}, \mathrm{S}$ en $G_{2} M$ een aanzienlijke spreiding te bestaan. Deze kan een partiele verklaring vormen voor de spreiding in de in de literaturur vermelde labelling indices. De intralaesionale spreiding in de percentages blijkt gering te zijn. Deze betrekkelijke homogenlteit is in overeenstemming met de histologische bevindingen van Fry \& McMinn (1970) en van Beek \& van Reede (1977). Daarentegen vinden Soltani \& van Scott (1972) in de rand van de laesie een hogere mitotische index, terwijl Christophers et al. (1973) met behulp van autoradiografie in het centrum meer DNA synthetiserende cellen vinden dan in de rand van de laesie. De bevindingen van Soltan \& Van scott (1972) zijn niet noodzakelijkerwijs in tegenspraak met de hier beschreven resultaten indien bij de preparatieprocedure van de epldermiscelien mitosen worden beschadigd. De verschillen in M.I. weerspiegelen dan een verlenglng van $T m$ in de periferie van de laesie. De variabilitelt in de gevonden DNA verdelingen berust voornamelijk op de interindividuele verschillen. Gezien deze bevindingen. wordt de sterk individueel bepaalde reactie op eenzelfde therapie van personen met klinisch gelijk uitziende psoriasislaesles verklaarbaar. Op analoge wijze moet het voor de diverse laesles soms sterk uiteenlopende therapieresultaat bij dezelfde persoon worden gezien.

In tegensteliling tot de verwachting op grond van het $\mathrm{kli-}$ nisch beeld 1 s de verhoging van het percentage $s$ bij onrustige psorlasis verrassend gering vergeleken met psoriasis vulgaris. 
In de snel voortschrijdende rand van een psoriasis pustulosa laesie blijkt meer dan $1 / 3$ van de prolifererende cellen zilch in de synthese fase te bevinden. De verandering in percentage $G_{2} M$ ligt, behalve bij patient 1 , niet in de orde van grootte van die van het percentage $S$. De hier weergegeven percentages stemmen overeen met de door Bauer \& Mali (1975) gevonden waarden bij psoriasis pustulosa. De klinische bevinding dat de epidermis na het passeren van het front weer redelijk normal wordt, wordt door deze metingen bevestiga.

Evenals bij normale epidermiscellen (hoofdstuk 4) kan het percentage $S$ of $G_{2} M$ verkregen uit flowcytometrische metingen van psoriasiscellen worden gebruikt voor de berekening van de turnovertijd van het levende epitheel als de duur van de $S$ of $G_{2} M$ fase bekend is. Uitgaande van de gevonden waarden 4,1 en 2,6 voor de ratio's $\mathrm{S} / \mathrm{G}_{2} \mathrm{M}$ in psoriasislaesie en normale huid en van een $T$ s in normale huid van 8 uur (Ge1fant, 1976) kan worden berekend dat:

$$
T_{s}\left(\text { laesie) }=-\frac{4,1}{2, \frac{1}{6}} \times 8= \pm 13\right. \text { uur. }
$$

De turnovertijd bedraagt dan:

$$
\begin{aligned}
T_{\text {turn ep }} & =-\frac{T_{S}}{S} \times 100 \\
& =-\frac{13}{9,7} \times 100=134 \text { uur }= \pm 5,5 \text { dagen. }
\end{aligned}
$$

Deze berekening berust op de verondersteliling dat de verandering in de ratio wordt veroorzakt door een verlenging van de $S$ fase dur terwijl $T-G_{2} M$ onveranderd blijft. De aldus gevonden warden stemmen in grote lijnen overeen met de schattingen van Van scott Ekel. (1963) gebaseerd op morphometrische metingen en mitose teilingen.

De celcyclustijd (TC) krijgt een waarden van 67 uur wanneer we aamemen dat de verhouding prolifererende en gedifferentieerde cellen ongeveer $1: 1$ bedraagt (Weinstein \& Housman, 1972). Dit is uiteraard een ruwe schating waarbij nog individuele verschillen kunnen optreden.

Voor psoriasis epidermis is algemeen aanvaard dat alle prolifererende cellen inderdaad aan de celcyclus deelnemen. Voor normale huid bestaat hierover twijfel (Gelfant, 1976). De geschatte TC van 139 uur voor normale epidermis (hoofastuk 4) is gebaseerd op de aanname dat alle prolifexerende cellen aan de cyclus deelnamen. Indien slechts een deel van de celien aan de celcyclus deelnemen wordt de celcyclustija 
korter. In felte zou het weleens zeer de vraag kunnen $z i j n$ of de celcyclustijd van een psoriasiscel zoveel korter is dan die van een normale epidermiscel. De abnormale celproductie moet dan geheel worden verklaard in termen van het aantal daadwerkelijk proliferende cellen per eenheid oppervlak, hetgeen dooy Chopra Elaxman (1974) uit in witro-studies is gesuggereerd. In verband hiermee is het onderzoek van Heeqen et al. (1979) van belang. vit computer simulatie studies concluderen $z i j$ dat een tijdelijke verschuiving in het normale evenwicht tussen de mate van celflow naar het gedifferentieerde en die naar het proliferatieve compartiment voldoende is om een permante toename in de germinatieve populatie te veroorzaken; dus zonder een verandering in de duur van de celcyclustijd zelf kan een verandering in epidermale morfologie in de richting van psoriasis worden gesimuleerd. De in dit hoofdstuk gevonden meetresultaten lijken deze hypothese te steunen ofschoon kleine veranderingen in de duur van de afzonderlijke celcyclusfasen bestaan (verlenging van de $s$ fase). In het licht van deze bevindingen verdient het concept van Gelfant (1978) aandacht dat bij de behandeling van psoriasis die therapiemethode waarbij psoriasiscellen worden gehinderd vanult de $G_{0}$ fase in de celcyclus te treder, bij voorkeur moeten worden onderzocht.

Morfologisch kan geen onderscheid worden gemaakt tussen normale epidermis en "gezonde" epidermis van personen met psoriasis. In het verleden hebben een aantal onderzoekers een verhoogde M.I. en labelling index in de "latent psoriatische epidermis" opgemerkt. De spreiding was echter zo groot dat in het individuele geval geen uitspraak over een eventuele psorlasis dispositie bij een persoon zonder klinische manifestatie van de ziekte kon worden gedaan (Braun-Falco et a1., 1967; Born \& Kalkoff, 1969).

Voor alle celcyclusfasen verschillen de met de flowcytometer gevonden DNA verdelingen significant van die voor normale epidermils. Deze bevinding kan op meerdere manieren worden verklaard. De percentages voor de $S$ en $G_{2} M$ fracties Iiggen tussen die voor normale en psoriasis epidermis in. Het verhoogde percentage $S$ kan worden verklaard door een langere Ts bij een gelijkblijvende totale celcyclustijd, zoals door pulimann $(1974,1978)$ is gevonden. Het feit dat de ratio $S / G, M$ niet groter wordt pleit hiertegen. Bovendien is het langerworden van de duur van de synthesefase omstreden (Weinstein \& Frost, 1968; Chopra \& Flaxman, 1974). De meest waarschijnlijke verklaring voor deze stijging is dat ook in de niet aangetaste epidermis de celcyclus reeds verkort is of dat de groeifractie is verhoogd. Op grond van bovengenoemde bevinding dat er mogelijk geen grote verschillen in celcyclustijd tussen normale en psoriasis epldermis zijn kan de toename van $S$ en $G_{2} M$ worden verklaard doox het feit dat in de niet aangetaste psoriasis huid de ratio non-cycling en wel de celoyclus doorlopende cellen verandert ten gunste van de latste. Na een geëigende stimulus zou deze ratio dan verder kunnen veranderen en leiden tot een klinisch manifeste psoriasislaesie. De niet angetaste psoriasis epidermis rea- 
geert op uiteenlopende noxen (mechanische, toxische, allergische), mits deze zowel het epitheel als het stratum papillare treffen, met de vorming van efflorescenties die kenmerkend zijn voor psoriasis (Heber, 1974); het isomorf prikke1effect (Koebner, 1877). Anderzijas kan ook een endogene stimulus b.v. in het kader van een infectie of geneesmiddelenexantheem, psoriasis provoceren (Steigleder \& Orfanos, 1967). Gezien onze meetresultaten lijken de niet aangetaste epidermiscellen reeds continu in een toestand van verhoogde proliferatieactiviteit. Een aspecifieke stimulus is kennelijk voldoende om de reeds veranderde regulatie van de groei verder te laten ontsporen.

De ratio $S / G_{2} M$ in de niet aangetaste epidermis verandert niet ten opzichte van normale epidermis. Deze waarneming lijkt de bevindingen van Steigleder \& Pullman (1979) dat Ts in de niet angetaste psoriasis epidermis is verlengd, niet te ondersteunen.

Flowcytometrische metingen van psoriasiscellen en van niet aangetaste epidermiscellen bij psoriasis geven nieuwe waarden en inzichten die echter aan grote beperkingen onderworpen zijn. Toekomstig onderzaek met multi-parameter flowcytometers, die het mogelijk moeten maken onderscheld te maken tussen gedifferentieerde keratinocyten en prolifererende epidermiscelien, en met flowcytometrische stathmokinetische methoden teneinde absolute celcyclustijden te verkrijgen, moet een verder inzicht geven in de celkinetische elgenschappen van psoriasiscellen. 
Bauer, F.W. \& Mali, J.W.H.: Use of cytophotometry for studying cell kinetics in a case of psorlasis pustulosa et arthropathica, Dermatologica, 151:164-167,1975.

Beck, H.P.: Effect of pepsin pretreatement on pulse cytometric DNA histograms. Cell and tissue Kinet. ,10:265-269, 1977.

Beek, C.H. \& van Reede, E.C.: The nature and frequency of the histological changes found in psoriasis vulgaris. Arch. Derm. Res.,257:255-264,1977.

Born, W. \& Kalkoff, K.W.:Zur DNS-Synthese der psoriatischen Epldermiszelle. Arch. kiln. exp. Derm.,236:43-52, 1969.

Braun-Falco, 0., Christophers, E. \& Kurban, A.: Abnormales Verhalten dex epidermalen Regeneration bei patienten mit Psoriasis vulgaris. Arch. klin. exp. Derm.,229:276-284,1967.

Chopra, D.P. \& Flaxman, B.A.: Comparative proliferative kinetics of cells from normal human epldermis and benign epidermal hyperplasia (psoriasis) in vitro. Cell and Tissue kinet. $, 7: 69-76,1974$.

Christophers, E., Parzefall, R. \& Braun-Falco, 0.: Initial events in psoriasis: quantitative assessment. Br. J. Derm., $89: 327-334,1973$.

Fry, L. \& McMinn, R.M.H. : The action of chemotherapeutic agents on psoriasis epidermis. Br. J. Derm.,80:373-383,1968.

Fry, L. \& McMinn, R.M.H.: Observations on mitosis in psoriatic epidermis. Br. J. Derm., 82:19-22, 1970.

Gelfant, S.: The cell cycle in psoriasis: a reappraisal, Br. J. Derm., 95:577-590,1976.

Gelfant S.: Guest editorlal. Understanding chemotherapy of psoriasis in terms of epldermal cell proliferation. Cell and Tissue Kinet., 11:577-579,1978.

Gommans, J.M., Bexgers, M., van Erp, P., van den Hurk, J., Mier, P.D., Roelfzema, $H_{*}$ : Studies on the plasma membrane of normal and psoriatic keratinocytes. Br. J. Derm.,101: $407-412,1979$.

Goodwin, P., Hamilton, S. \& Fy, I.: A comparison between DNA synthesis and mitosis in uninvolved and involved psoriatic epidermis and normal epidermis. Br. J. Derm.,89: $613-6-18,1973$.

Goodwin, P., Hamilton, S. \& Fry, L.: The cell cycle in psoriasis. Br. J. Derm. ,90:517-524,1974. 
Grove, G.L.: Epidermal cell kinetics in psoriasis, present status. Int. J. Derm., 18:111-119,1979.

Heber, W.: Isomorpher Reizeffekt bei Psoriasis vulgaris. Hautarzt, $25: 211-218,1974$.

Heenen, M., De Martelaer, V. \& Galand, P.: Psoriasis and cell cycle: a computer simulation. Acta Dermatovener.

(Stockholm) Suppl, ,87:73-82,1979.

He11, E. \& Hodgson, C.: The uptake of $\mathrm{H}^{3}$-thymidine by epidermal cells in normal and psoriatic subjects. Br. J. Derm., $78: 262-268,1966$.

Kaidbey, K.H. \& Kurban, A.K.: Mitotic behaviour of the buccal mucosal epithelium in psoriasis. Br. J. Derm., 85:162-166, 1971.

Koebner, H.: Zur Aetiologie der Psoriasis. Vjschr. Derm. Syph., $4: 203-207,1877$.

Mie, N.H.: Statistical. Package for the Social Sciences. MC. Graw-Hi11, London, 1975 .

Pullmann, H., Lennartz, K.J. \& Steigleder, G.K. : In vitro examination of cell proliferation in normal and psoriatic epidermis with special regard to diurnal variations. Arch. Derm. Forsch.,250:177-184,1977.

Pullmann, H.: Autoradiographie-Untersuchung der Zellproliferation bei Psoriasis vulgaris. Grosse Scripta 3, Grosse Verlag, Berlin, 1978 .

Soltani, K. \& Van scott, E.J.: Patterns and sequence of tissue changes in inclpient and evolving lesions of psoriasis. Arch. Dermatol., 106:484-490,1972.

Steigleder, G.K. \& Orfanos, C.E.: Provozierte Psoriasis. Hautarzt, $18: 508-514,1967$.

Steigleder, G.K. \& Pullmann, H. : Cell proliferation $\mathbb{1 n}$ Psoriasis. Acta Dermatovener. (Stockholm) Supp 1., B7:64-72,1979.

U.R.C. (Universitair Reken Centrum) Nijmegen, Release on I.B.M. $370 / 158,1979$.

Van Scott, E.J. \& Ekel, T.M.: Kinetics of hyperplasia $1 n$ psoriasis. Arch. Dermatol.,88:373-381, 1963.

Weinstein, G.D. \& Frost, P.: Abnormal cell proliferation in psorlasis. J. Invest. Derm., 50:254-259,1968.

Weinstein, G.D. \& Housman, R.: Interrelationship of epidermal proliferative and differentiated cell kinetics. I. Invest. Derm. $58: 265-272,1972$. 
Wohlrab, W. Gruneberg, T.: Histochemische Befunde an der klinisch gesunden Haut von Psoriatikern. Arch. klin. exp. Derm, $225: 259-266,1966$. 
HOOFDSTUK 6

DNA DISTRIBUTIE IN ENKELE ANDERE DERMATOSEN.

6.1. Inleiaing

6.2. Materiaal en methode

6.3. Resultaten

6.3.1. Neurodermitis

6.3.2. Lichen ruber planus

6.3.3. Morbus Darier (dyskeratosis follicularis)

6.3.4. Normale epidermis versus niet aangetaste epidermis bij personen met neurodermitis, resp. lichen ruber planus, resp. M. Darier

6.3.5. Normale epidermis versus laesie van neurodermitis, lichen ruber planus en M. Darier

6.3.6. Psoriasis vulgaris versus neurodermitis, lichen ruber planus en M. Darier

6.4. Discussie

6.5. Referenties 
DNA DISTRIBUTIE IN ENKELE ANDERE DERMAMOSEN.

6. 1. INLEIDIMG.

De DNA verdeling in psoriasiscellen is significant verschiliend van die in normale epidermiscellen. In antwoord op de vraag of deze veranderingen speciflek voor psoriasis zijn, is bij een arietal genetisch bepalde huidaandoeningen, die slechts onder bepaalde omstandigheden manifest worden, en waarbij mogelijk een storing in het verhoorningsproces bestaat, de DNA verdeling in de epidermiscellen bepaald. Neurodermitis is gekozen op grond van de vaak grote overeenkomsten in histologisch beeld met psoriasis. Lichen ruber planus is een storing in het verhoorningsproces van de epidermiscellen, hetgeen zich uit in verdikking van het stratum granulosum en stratum corneum. Morbus Darier (ayskeratosis follicularis) tenslotte is gekozen op grond van het feit dat hier eveneens sprake is van een verhoorningsstoornis, die histologisch beperkt is tot de epidermis.

ook in de niet aangetaste psoriasishuid zijn verschillen in DNA verdeling t.o.v. normale epidermiscellen aantoonbaar. Het lijkt zinvol bij bovengenoemde dermatosen de DNA distributie van de cellen in de niet aangetaste epidermis te bepalen.

6. 2. MATERIAAI EN METHODE.

De monsters zijn genomen uit nog niet behandelde laesies van neurodermitis, lichen ruber planus en $M$. Darier van personen die de polikliniek dermatologie bezochten. Tevens zijn bij een aantal van deze personen monsters genomen uit de normaal vitziende huid van indien mogelijk arm of rug. Alle metingen vonden plaats in de periode juni-juli.

De proliferatiepationen van de monsters zijn op de in hoofastuk 3 beschreven wijze bepaald. De statistische analyse geschiedde met de simpele t-test en is uitgevoerd met spsS subprogramma's (Nie, 1975; U.R.C.,1979). De signiflcantie is getoest op een onbetrouwbaarheidsgrems van 58 .

6. 3. RESULTATEN.

6.3. 1. NEURODERMITIS.

Tussen de gemiddelde percentages voor de diverse fracties van de celcyclus van resp. neurodermitis-cellen en epi- 
dermiscellen uit de niet aangetaste huid van personen met neurodermitis bestaan wat betreft de $2 \mathrm{c}$ en $S$ fractie significante verschillen. De $G_{2} M$ fractie en de ratio $S / G_{2} M$ zijn niet significant verschillend (tabel 6.1.).

Tabel 6.1.

\begin{tabular}{lccccc}
\hline & $\mathrm{n}$ & $2 \mathrm{c}$ & $\mathrm{s}$ & $\mathrm{G}_{2} \mathrm{M}$ & $\mathrm{S} / \mathrm{G}_{2} \mathrm{M}$ \\
\hline $\begin{array}{l}\text { Laesie } \\
\text { Niet aange- }\end{array}$ & $91,3 \pm 3,1$ & $6,1 \pm 1,6$ & $2,5 \pm 1,9$ & $3,9 \pm 4,1$ \\
taste huid & 10 & $95,8 \pm 0,9$ & $2,8 \pm 0,7$ & $1,5 \pm 0,4$ & $1,9 \pm 0,4$ \\
Significantie $\mathrm{p}$ & $<0,18$ & $<0,18$ & 98 & 158 \\
\hline
\end{tabular}

Tabel 6.1.: Analyse van de DNA verdelingen in procenten in laesies en niet aangetaste huid van personen met neurodermitis met behulp van de t-test.

6.3.2. LICHEN RUBER PLANUS.

Tussen laesies en niet aangetaste huid bij personen met lichen ruber planus bestaan wat betreft de hier onderzochte parameters geen significante verschillen. Ook de ratio's $S / G_{2} M$ van de niet aangetaste huid en van de laesie bij deze aandoening zijn niet significant verschillend (tabel 6.2.).

Tabel 6.2.

\begin{tabular}{lccccc}
\hline & $\mathrm{n}$ & $2 \mathrm{c}$ & $\mathrm{s}$ & $\mathrm{G}_{2} \mathrm{M}$ & $\mathrm{s} / \mathrm{G}_{2} \mathrm{M}$ \\
\hline $\begin{array}{l}\text { Laesie } \\
\begin{array}{l}\text { Niet aange- } \\
\text { taste huid }\end{array}\end{array}$ & 6 & $94,9 \pm 0,6$ & $3,7 \pm 0,4$ & $1,4 \pm 0,3$ & $2,8 \pm 0,5$ \\
Significantie & $\mathrm{p}$ & $94,9 \pm 1,3$ & $3,3 \pm 0,9$ & $1,8 \pm 1,0$ & $2,3 \pm 1,2$ \\
\end{tabular}

Tabel 6.2.: Analyse van de DNA verdelingen in procenten in laesies en niet aangetaste huid van personen met lichen ruber planus met behulp van de tr-test.

6.3.3. MORBUS DARIER.

Bij $M$. Darier bestaan wat betreft de $2 \mathrm{C}$, $S$ en $\mathrm{G}_{2} \mathrm{M}$ fractie alsmede wat betreft de ratio $S / G_{2} M$ geen significante verschillen tussen laesie en normaal uitziende huid bij deze 
aandoening (tabe 16.3.$)$.

Tabe1 6.3 .

$$
\mathrm{n} \quad \mathrm{2c} \quad \mathrm{s} \quad \mathrm{G}_{2} \mathrm{M} \quad \mathrm{s} / \mathrm{G}_{2} \mathrm{M}
$$

$\begin{array}{lccccc}\text { Laesie } & 8 & 93,4 \pm 1,3 & 4,3 \pm 1,2 & 2,2 \pm 0,3 & 2,0 \pm 0,6 \\ \text { Niet ange- } & & 95,4 \pm 1,7 & 2,9 \pm 1,0 & 1,8 \pm 0,7 & 1,7 \pm 0,3 \\ \text { taste huid } & 3 & 78 & 108 & 138 & 418\end{array}$

Tabel 6.3.: Analyse van de DNA verdelingen in procenten in laesies en niet aamgetaste huid van personen met $M$. Darier met behulp van de $t$-test.

6.3.4. NORMALE EPIDERMIS VERSUS NIET AANGETASTE EPIDERMIS VAN NEURODERMITIS, LICHEN RUBER PLANUS EN M. DARIER.

Bij vergelijking van de verdeling van het DNA gehalte in de epidermiscellen afkomstig uit de niet aangetaste huid van personen met neurodermitis, resp. lichen ruber, resp. $M$. Darier met de DNA verdeling in normale huid van controle personen komen geen significante verschillen naar voren (tabe 16.4.$)$.

Tabe1 6.4.
$\mathrm{n}$
$2 \mathrm{c}$
$\mathrm{S}$
$\mathrm{G}_{2} \mathrm{M}$
$\mathrm{S} / \mathrm{G}_{2} \mathrm{M}$

Normale epid. $60 \quad 95,9 \pm 1,1 \quad 2,8 \pm 0,8 \quad 1,3 \pm 0,6 \quad 2,6 \pm 1,1$

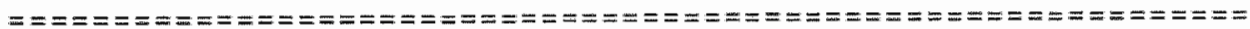
Neuradermitis $10 \quad 95,8 \pm 0,92,8 \pm 0,7 \quad 1,5 \pm 0,41,9 \pm 0,4$ Significantie $p \quad 8 \% \quad 82 \% \quad 51 \%$

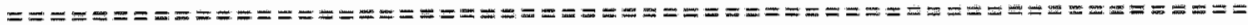

$\begin{array}{lccccc}\text { Lichen ruber } & 7 & 94,9 \pm 1,3 & 3,3 \pm 0,9 & 1,8 \pm 1,0 & 2,3 \pm 1,2 \\ \text { Significantie } & \mathrm{p} & 118 & 248 & 78 & 428\end{array}$

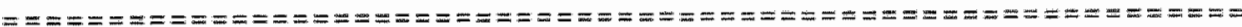

M. Darier $395,4 \pm 1,72,9 \pm 1,01,8 \pm 0,71,7 \pm 0,3$ $\begin{array}{llllll}\text { Significantie } \mathrm{p} & 59 \% & 97 \% & 12 \%\end{array}$

Tabel 6.4.: Vergelijking van de DNA verdelingen in procenten van epldermiscelien uit de niet aangetaste huid van personen met resp. neurodemitis, lichen ruber planus en M. Darler met de DNA verdeling in de normale huid van controle personen. 
6.3.5. NORMALE EPIDERMIS VERSUS LAESIE VAN NEURODERMITIS, LICHEN RUBER PLANUS EN M. DARIER.

Ex bestaan significante verschilien voor wat betreft de hier ondexzochte parameters tussen neurodermitis-laesies en de normale epidermis. Bij Ilchen ruber zijn deze verschilien niet aanwezig. Bij M. Darier zijn de verschillen juist significant voor de $20, S$ en $G_{2} M$ fractie. De ratio $S / G_{2} M$ is niet verschillend. Zaals reeds eerder is wermeld $z$ ijn er uitgesproken significante verschillen in DNA verdeling tussen psoriasislaestes en normale epidermis (tabe 16.5.$)$.

Tabe 16.5 .

$n \quad 2 \mathrm{c} \quad \mathrm{s} \quad \mathrm{G}_{2} \mathrm{M} \quad \mathrm{s} / \mathrm{G}_{2} \mathrm{M}$

Normale epi-

dermis $\quad 60 \quad 95,9 \pm 1,1 \quad 2,8 \pm 0,8 \quad 1,3 \pm 0,6 \quad 2,6 \pm 1,1$

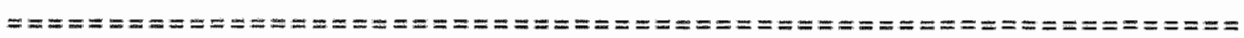
Neurodermitis $18 \quad 91,3 \pm 3,1 \quad 6,1 \pm 1,6 \quad 2,5 \pm 1,9 \quad 3,9 \pm 4,1$ Signif. P $0,1 \% 0,180,980$

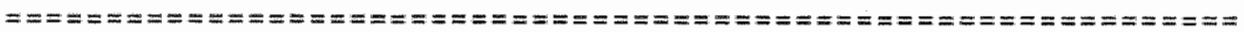
Lichen ruber $694,9 \pm 0,6 \quad 3,7 \pm 0,4,1,4 \pm 0,32,8 \pm 0,5$ Signif. p $438 \quad 30 \% \quad 90 \%$

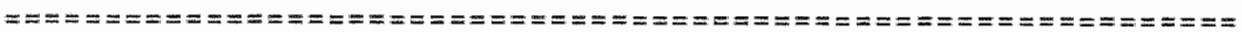
$\begin{array}{lrrccc}\text { M. Darier } & 8 & 93,4 \pm 1,3 & 4,3 \pm 1,2 & 2,2 \pm 0,3 & 2,0 \pm 0,6 \\ \text { Signif. } & & 28 & 4,28 & 4,48 & 448\end{array}$

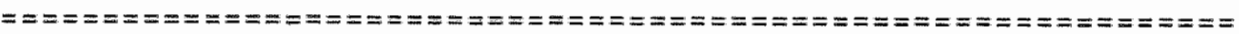
Psoriasis $\quad 9487,3 \pm 3,49,7 \pm 2,62,9 \pm 1,4 \quad 4,1 \pm 2,2$

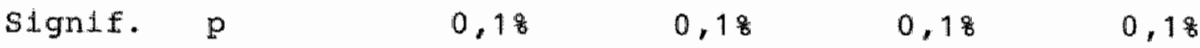

Tabel. 6.5.: Vergelijking van de DNA verdeling is normale huld van controle personen met de DNA verdeling in epidermale celsuspensles afkomstig uit laesies van resp. neurodermitis, lichen ruber, $M$. Darier en psordasis.

6.3.6. PSORIASIS VULGARIS VERSUS NEURODERMITIS; LICHEN RUBER PLANUS EN M. DARIER.

Blj vergelijking van de DNA verdeling van epidermiscellen uit laesies van bovengenoemde drie huidafwijkingen met psorlasis vulgarls laesies komen in de $2 \mathrm{c}$ en $\mathrm{S}$ fractie significante verschillen naar voren. De $G_{2} M$ fractie is alleen bij lichen ruber slgnificant verschiliend van psoriasis. 
De ratio $\mathrm{S} / \mathrm{G}_{2} \mathrm{M}$ is alleen significant verschiliend voor $\mathrm{M}$. Darier (tabeI 6.6.).

Tabel 6.6 .
$\mathrm{n}$
$2 \mathrm{c}$
$S$
$\mathrm{G}_{2} \mathrm{M}$
$\mathrm{S} / \mathrm{G}_{2} \mathrm{M}$

Psoriasis $\quad 94 \quad 87,4 \pm 3,4 \quad 9,7 \pm 2,6 \quad 2,9 \pm 1,4 \quad 4,1 \pm 2,2$

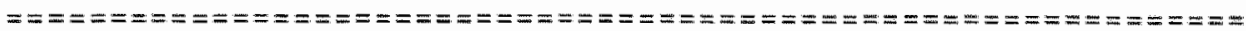

Neurodermitis $1891,3 \pm 3,16,1 \pm 1,6 \quad 2,5 \pm 1,9 \quad 3,9 \pm 4,1$

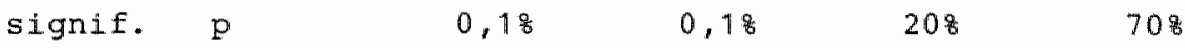

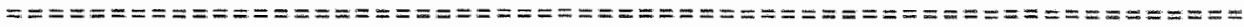

Lichen ruber $694,9 \pm 0,6 \quad 3,7 \pm 0,4 \quad 1,4 \pm 0,3 \quad 2,8 \pm 0,5$ Signif. p $\quad 0,1$ 용 $0,180,38 \quad 158$

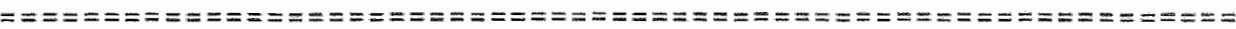

M. Darier $893,4 \pm 1,34,3 \pm 1,2 \quad 2,2 \pm 0,3 \quad 2,0 \pm 0,6$

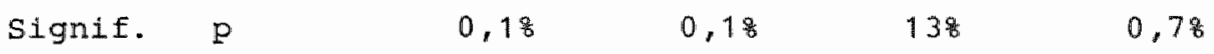

Tabel 6.6.: Vergeljjking van de DNA verdeling in procenten in psoriasis vulgaris laesies met de DNA verdelingen in epidermale celsuspensies afkomstig uit resp. neurodermitis, lichen ruber en $M$. Darier laesies.

6. 4. DISCUSSIE.

Epidermale cellen in neurodermitis laesies verschillen significant in DNA distributie van normale epidermiscellen. Het aantal cellen in de $s$ fase van de celcyclus is duidelijk verhoogd vergeleken met de niet aangedane huid bij deze aandoening (tabe1.6.1.) en met de normale huid van controle personen (tabel 6.5.). Het percentage $s$ is bij neurodermitis significant lager dan dat van psoriasislaesies (tabel 6.6.). Neurodermitis laesies zijn derhalve met de flowcytometer op grond van het afwijkende percentage cellen met een DNA gehalte van de kern tussen $2 \mathrm{c}$ en $4 \mathrm{c}$ te differentierren van normale epidermis en van psoriasis vulgaris.

In de ons bekende literatuur hebben we geen gegevens over de mate van proliferatie van de epidermis bij neurodermitis gevonden. Over de betekenis van het hogere percentage $s$ bij neurodermitis kan geen zekere uitspraak worden gedaan. Uit het veranderen van de ratio $\mathrm{s} / \mathrm{G}_{2} \mathrm{M}$ kan men wel concluderen dat bij neurodermitis, evenals dit het geval is bij psorlasis, veranderingen in de celcyclus optreden t. o.v. normale epidermis.

De niet aangedame huid en de laesies bij̆ neurodermitis ver- 
schillen significant voor wat betreft de 20 en $S$ fractie (tabel 6.1.). De $G_{2} M$ fractie en de ratio $S / G_{2} M$ zijn in deze metingen niet significant verschillend ofschoon er in de berekende warden schijnbaar grote verschillen $z i j n$. Dit berust op de grote standaarddeviatie in de $S$ en $G_{2} M$ fractie. Bij zowel psoriasis als neurodemitis is er, zij het in uiteenlopende mate, een toename van het aantal DNA synthetiserende cellen. De ratio $\mathrm{S} / \mathrm{G}_{2} \mathrm{M}$ verschilt bij deze aandoeningen niet. In theorie is de mogelijkheld aanwezig dat bij belde aandoeningen een, verschillend grote, toename van de groelfractie bestaat. Voor psorlasis is een dergelijke toename aangetoond (Chopra \& Flaxman, 1974). Ook een verkorting van de totale celcyclustija geeft een toename van het percentage $S$ bij gelijkblijvende ratio.

Het aantal DNA synthetiserende cellen in lichen ruber laesies is in onze metingen niet significant hoger dan in de niet angedane huid bij deze aandoening (tabel 6.2.) of in de normale huid van controle personen (tabel 6.5.). Deze bevinding stemt overeen met de studie van Walker \& Dolby $(1974)$, die geen verschil in labelling index tussen lichen ruber laesies en normale huid van controle personen vinden. Daarentegen is de proliferatie volgens Lever (1967) en volgens Pinkus \& Mehregan (1969) verlaagd in lichen ruber laesies. Op hun beurt vinden Marks et al. (1973) en Ebner et al. (1977) een verhoging van de L.I. zowel in de laesie als in de normal uitziende huid van lichen ruber vergeleken met de epldermis van controle personen.

Onze metingen suggerexen dat de mogelijke storing in het verhoorningsproces bij lichen ruber niet moet worden gezocht in de richting van een toegenomen proliferatie. Het door Marks et al. (1973) en Presbury \& Marks (1974) voorgestelde concept dat bij lichen ruber een repopulatie van de beschadigde basale cellen door keratinocyten uit de rand van de laesie plaatsvindt, is hiermee niet in tegenspraak. Lichen ruber laesies en psorlasislaesies verschillen significant in aantal. DNA synthetiserende cellen.

Epldermiscellen afkomstig uit laesies van M. Darier hebben een DNA verdeling van de kern die wat betreft de $S$ en $G_{2} M$ fractle net signiflcant verschilt van die van normale huid van controle personen (tabel 6.5.). Tussen laesie en klinisch niet aangetaste huid bij deze aandoening bestaan geen signiflcante verschilien in DNA verdeling (tabel 6.3.). De klinisch normal uitzlende huid bij $M$. Darier verschilt in de hiler gemeten parameters niet van normale huld. Deze schijnbare tegenspraak berust mogelijk op het kleine aantal gemeten proefpersonen.

Tussen M. Darier en psoriasislaesie zijn er significante verschillen in antal DNA synthetiserende cellen.

De niet aangedane huid van de 3 besproken huidaandoeningen verschilt niet wat de hier gemeten parameters betreft van 
normale huid van controle personen. De normal uitziende huid van personen met psoriasis is daarentegen wel significant verschillend van normale epidermis. Deze discrepantie vormt een aanwijzing dat er een verschil in aetiologie tussen psoriasis en neurodermitis kan bestaan. Mogelijk is de storing in de regulatie van de groel bij psoriasis central gelocaliseerd, waardoor de gehele epidermis reeds een veranderd proliferatiepatroon heeft, waarbij door aspecifieke stimuli klinisch manifeste psoriasislaesies kunnen ontstaan. Bij neurodermitis, waarbij eveneens een toename van de proliferatie, zij het in geringere mate dan bij psoriasis, blijkt te bestaan, bestaat mogelijk een locale storing in de groeiregulatie, waarbij de regulatie in de niet angedane epidermis normaal blijft.

De doelstelling van dit hoofdstuk is de beantwoording van de vraag of de afwijkende DNA verdeling in de kernen van de epidermiscellen bij psoriasis specifiek is voor deze aandoening. Aan de hand van de verkregen meetresultaten blijkt dat psoriasiscellen inderdaad flowcytometrisch kunnen worden gedifferentiëerd van epidermiscellen afkomstig van een aantal andere huidaandoeningen die eveneens op een mogelijke storing in thet verhoorningsproces berusten. 
Chopra, D.P. Flaxman, B.A. : Comparative proliferative kinetics of cells from normal human epidermis and benign epidermal hyperplasia (psoriasis) in vitro. Cell Tissue kinet., $7: 69-76,1974$.

Ebner, H., Gebhart, W., Lassmann, H. \& Jurecka, W.: The epidermal cell proliferation in lichen planus. Acta Dermatovener. $, 57: 133-136,1977$.

Lever, W.F.: Histopathology of the skin. 4th edn, pag.157, J.B. Lippincott, philadelphia.

Marks, R., Black, M. \& Wilson Jones, E.: Epidermal cell kinetics in lichen planus. Br. J. Derm., 88:37-45,1973.

Nie. N.H.: Statistical Package for the Social Sciences. Mc Graw-Hi1, Londion, 1975 .

Pinkus, H. \& Mehregan, A.H.: A guide to Dermatohistopathology., pag 123, Butterworhts, London, 1969.

Presbury, D.G.C. \& Marks, R.: The epidermal disorder in 1ichen planus: an in vitro study. Br. J. Derm.,90:373-380, 1974.

U.R.C. (Universitair Reken Centrum), Nijmegen, Release 7.02 on I.B.M. $370 / 158,1979$.

Walker, D.M. \& Dolby, A.E.: Labelling index in the mucosal lesions of lichen planus. Br. J. Derm.,91:549-556,1974. 
HOOFDSTUK 7.

FLOWCYTOMETRISCHE BEPALING VAN DE THERAPIE-EFFECTEN VAN EEN AANTAL VEEL TOEGEPASTE THERAPIEREGIMES BIJ PSORIASIS VULGARIS.

7. 1. Inleiding

7.2. Dithranol.

7.2.1. Inleiding

7.2.2. Materiaal en methode

7.2.3. Resultaten

7.2.4. Discussie

7.3. Photochemotherapie

7.3.1. Inletding

7.3.2. Goeckerman theraple.

7.3 .2 .1 . Inleiding

7.3.2.2. Materiaal en methode

7.3.2.3. Resultaten

7.3 .2 .4 . Discussie

7.3.3. P.U.V.A.

7.3.3.1. Inleiding

7.3.3.2. Materiaal en methode

7.3.3.3. Resultaten

7.3.3.4. Discussie

7.4. Röntgen therapie

7.4.1. Inledding

7.4.2. Materiaal en methode

7.4.3. Resultaten

7.4.4. Discussie

7.5. Referenties 
FLOWCYTOMETRISCHE BEPALING VAN DE THERAPIE-EFFECTEN VAN EEN AANTAL VEEL TOEGEPASTE THERAPIEREGIMES BIJ PSORIASIS VULGARIS

7. 1. INLEIDING.

De behandeling van psoriasis is nog steeds voor een belangrijk deel gebaseerd op emptrie. Deze therapie bestaat uit applicatie van lokale agentia, soms in combinatie met systemische chemotherapeutica. Het aangrijpingspunt en werkingsmechanisme van deze medicamenten op celkinetisch niveau is vaak nog in duisternis gehuld. ook de rationele achtergrond van het combineren van de divexse therapeutische mogelijkheden ontbreekt nog.

Flowcytometrisch onderzoek van een epidermale celsuspensie makt het mogelijk binnen korte tijd het aantal cellen in de $S$ en $G_{2} M$ fase te bepalen. Het proliferatiepatroon van de epidermiscellen uit een psoriasislaesie versch1lt significant van dat van klinisch niet aangetaste epidermiscellen (cf. hoofdstuk 5). Nadat een psoriasislaesie onder invloed van therapie is verdwenen is er in de DNA histogrammen geen onderschelld meer tussen de epidermiscellen van de plaats van de voormalige laesie en van de overige niet aangetaste epidermiscelien.

Het lijkt zinvol de veranderingen in proliferatieactiviteit die tijdens de therapeutisch geinduceerde genezing van een psoriasisplek optreden met behulp van de flowcytometer te volgen. In dit hoofdstuk worden de flowcytometrische bevindingen tijdens dithranol (cignoline ${ }^{R}$ ) applicatie, teerbad-hoogtezon behandeling, PUVA therapie en röntgenbestraling weergegeven.

7.2. DITHRANOL (CIGNOLINE ${ }^{\mathrm{R}}$ ).

\subsubsection{INLEIDING.}

De monografie van de Engelse dermatoloog Balmanno Squire in 1878 over ruw chrysarobine gaf de beslissende impuls voor de invoering van goa-poeder in de westerse geneeskunst en zijn toepassing als theraple van in het bijzonder psoriasis maar ook van lichen ruber, acne, rosacea, pityriasis versicolor en andere chronische dermatosen (Weirich \&ettlewe 11,1972). Dithranol (1,8 dihydroxy-anthranol = anthraline = cignoline ${ }^{R}$ ) is door unna en Galewsky in 1916 genntroduceerd als substituut voor chrysarobine, dat inconstant in samensteling, wisselvallig in anti-psoriatisch effect en veranderlijk in chemische stabiliteit is. In $1953 \mathrm{pu}-$ 
bliceerde Ingram $(1953,1954)$ de methode om dithranol in de stijve pasta Lassar te appliceren in combinatie met teer en $u . v$. straling. Comaish $(1965,1971)$ modificeerde het Ingram regime door oplopende concentraties dithranol te appliceren. Roxtarende applicatie wan hoge concentraties dithranol is de laatste ontwikkeling op het gebied van psoriasis behandeling met dithranol (schaefer et al "1980).

Dithranol dringt snel de levende epidermis binnen en wordt in het stratur spinosum geoxydeerd (Kammerau et al.,1975; Selim et a1. "1981). De intrinsieke instabiliteit wan het anthraline molecuul, die leidt tot het ontstaan van meerdere derivaten, bemoeilijkt het onderzoek naar het werkingsmechanisme op moleculalr niveau aanzienlijk. Dithranol heeft meeraere effecten op de epidermis.

Dithranol vormt complexen met DNA (Swanbeck \& Thyresson, 1965: Swanbeck \& zetterberg,1971). De ligging van dithrano1 tussen elke achtste basenpaar in leidt tot verstoring van de matrix en $z o$ tot stilstand van de DNA replicatie. In tegenstelling tot de klinische evvaring zou ditranol in lage concentratles carcinogeen zijn (Segal et al.,1971; zetterberg Swanbeck, 1971). Complexvorming met FNA is omstreden (Weigand Everett, 1967). Het vermogen van de cellen om aninozuren te incorporeren in elwitten wordt door dithranol niet angetast; wel wordt de thymidine inbouw in DNA in met de $t$ ijd toenemende mate geremd (Klem, 1978).

Tevens leldt ditranol in therapeutische concentraties tot enzyminhibitie. De enzymactiviteiten van de pentose-fosfaat shunt (glucose-6-fosfaat dehydrogenase) en van de anaerobe glycolyse (glyceraldehyde-3-fosfaat dehydrogenase, lactlicodehydrogenasej worden het sterkst geremd. Andere enzymsystemen (ademhalingsketen, hydrolyse, citroenzuur cyclus) worden niet of slechts in geringe mate geremd (Melers et a1.,1968; Raab,1969; Braun-Falco et a1.,1971; Rassner, 1971; cotton \& v Rossum, 1975). De inhibitiepercentages verschillem sterk, afhankelijk van de methode van bepaling. In psoriasiscellen 1 s de activiteit van de enzymen van de glycoloyse met een facor 2 en var de enzymen, die betrokken zijn bij de pentose-fosfaat shunt, met een factor 4 verhoogd. In een therapeutische concentratie kan dithranol de activiteit van glyceraldehyde-3-fosfat dehydrogenase in de epidermis in 6 dagen tot normale waarden en de activiteit van G-6-PD tot bijna normale warden terugbrengen. Het is nog niet geheel. duldelijk of dithranol een direct effect op deze enzymen heeft of indirect door reactie met co-enzymen aangrijpt.

Dithranol wordt in de epidermis geoxydeerd (Lehmann, 1965). De auto-oxydatie van dithranol verloopt via meerdere vrije radicalen en leidt tot zeer reactieve dithranol radicalen en univalente reductieproducten van zuurstof. Volgens som- 
mige auteurs zouden destructieve radical reacties verantwoordelijk zijn voor het therapeutisch effect (Mustakallio, 1981; Martinmaa et a1., 19811.

7.2.2. MATERIAAL EN METHODE.

Van 11 personen met psoriasis vulgaris, die klinisch behandeld werden met cignoline pasta (cignoline, vaste parafine 1.25\%, vloeibare paraffine 1,25\%, pasta Lassarl te beginnen met $0,05 \%$ en overeenkomstig het klinisch beeld opklimmend tot 3 \% cignoline, werden meerdere malen per week huidmonsters afgenomen. De monsters zijn alle uit dezelfde psoriasislaesie genomen, omdat tussen twee psoriasis plaques aanzienlijke verschilien kunnen bestaan (Cox \& Watson, 1972 ; cf. hoofdstuk 51 . Tevens zijn gelijktijdig huidmonsters genomen uit de klinisch niet aangetaste, niet behandelde huid. De patienten werden dagelijks met bovengenoemde pasta behandeld. Geen van de patienten ontving een andere locale of systemische therapie.

Afname en bewerking wan de huldmonsters en meting en analyse van de celsuspensies geschiedde als beschreven in hoofdstuk 3.

7.2.3. RESULTATEN.

Bij alle onderzochte patienten treedt in de DNA histogrammen in de loop van de behandeling een asymmetrie van de $2 \mathrm{c}$ plek op (fig.7.2.1.). Deze asymmetrie wordt niet gevonden in de niet behandelde, klinisch normal uitziende huid. Bij continueren van de therapie verdwijnt de asymmetrie weer. De berekende percentages voor de $S$ fractie dalen in de loop van de tijd, redelijk in overeenstemming met het verschijnen van de klinische verbetering. Uiteindelijk worden, wanneer de behandelde psoriasis plek klinisch geheel is genormaliseerd, waarden voor de $s$ fractie gevonden die liggen in het spreldingsgebied van de klinisch normale huid van psoriasis patienten.

De $G_{2} M$ warden vertonen tijdens de aithranol behandeling geen extravagante reactie. Bij een antal van de onderzochte personen treedt een geleidelijke daling van het aantal tetraploide cellen in de DNA histogrammen op tot het niveau van de klinisch niet aangetaste epidermis. Tabel 7.2.1. toont de in het verloop van de behandeling gevonden percentages voor de $20, s$ en $G_{2} M$ fractie van een met athranol behandelde psoriasis plek.

Figuur 7.2.1. toont een voorbeeld van de voorbijgaande asymmetrie van de $2 c$ piek in de DNA histogrammen van celsuspensies afkomstig uit met dithranol behandelde psoriasislaesies. 
E.g. $7.2 \cdot 1$.
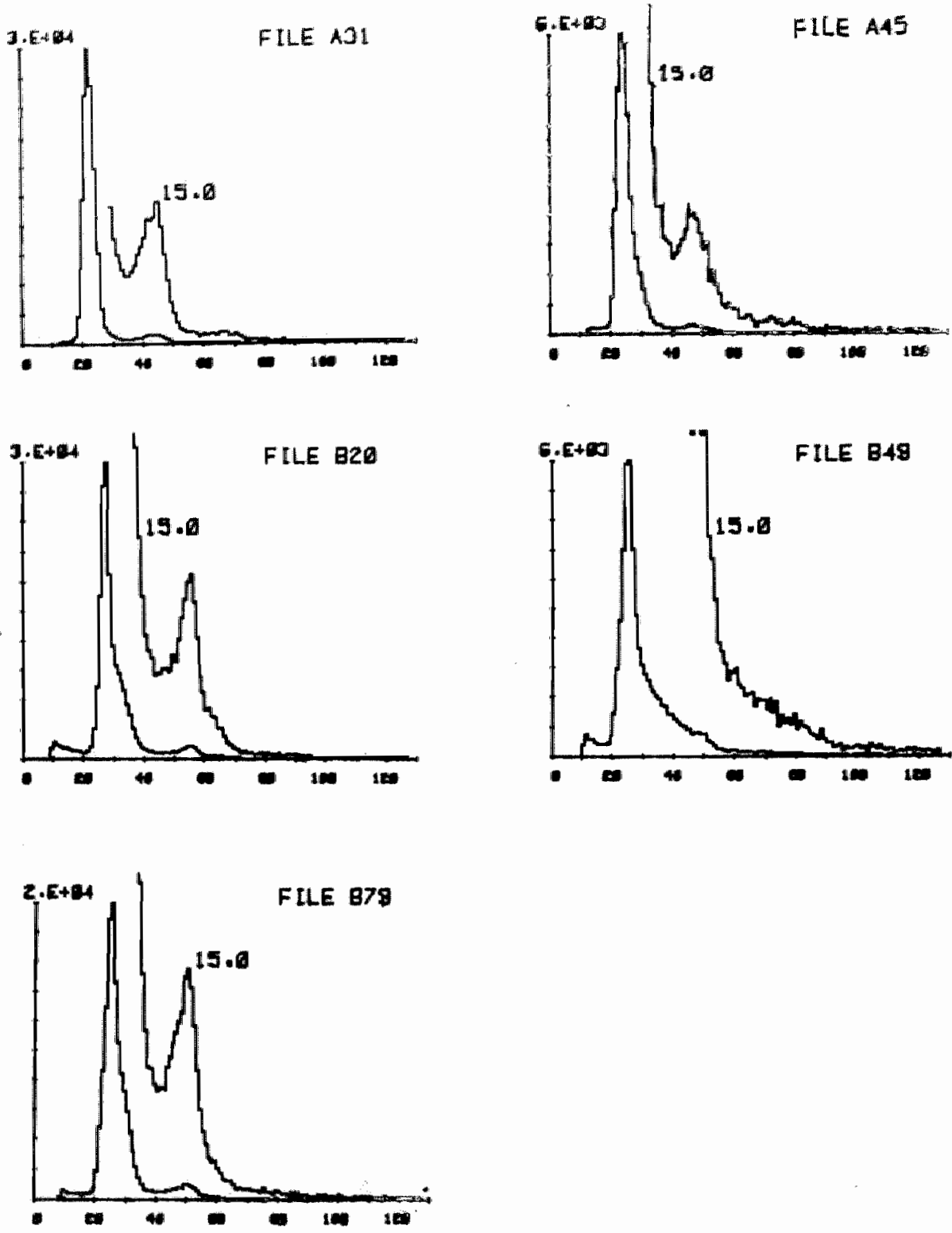

Fig. 7.2.1.: Voorbeeld van de voorbijgaande asymmetrie van de $2 \mathrm{c}$ piek in de DNA histogrammen van celsuspensies afkonstig uit met aithranol behandelde psoriasislaesies. 
Tabel 7.2.1.

\begin{tabular}{lcccc}
\hline$T$ & $\mathrm{~T}$ & $\mathrm{~s}$ & $\mathrm{G}_{2} \mathrm{M}$ & $\mathrm{S} / \mathrm{G}_{2} \mathrm{M}$ \\
\hline 0 & 84,7 & 11,6 & 3,7 & 3,1 \\
3 & 86,6 & 10,5 & 2,9 & 3,6 \\
4 & 90,1 & 7,1 & 2,8 & 2,5 \\
5 & 86,3 & 10,3 & 3,4 & 3,0 \\
6 & 88,7 & 8,9 & 2,4 & 3,7 \\
9 & 87,3 & 9,6 & 3,0 & 3,2 \\
10 & 91,8 & 5,5 & 2,7 & 2,0 \\
11 & 91,4 & 7,0 & 1,6 & 4,4 \\
12 & 93,0 & 5,4 & 1,6 & 3,4 \\
15 & 93,3 & 4,9 & 1,8 & 2,7 \\
18 & 94,2 & 4,0 & 1,8 & 2,2 \\
\hline
\end{tabular}

Tabe1 7.2.1.: Overzicht van de gemeten percentages epidexmiscellen in de $2 c, S$ en $G_{2} M$ fase in de DNA histogrammen, alsmede de ratio $S / G_{2} M$, van een persoon met psoriasis vulgaris na behandeling met locale dithranol applicatie. $T=t i j d$ in dagen na anvang van de dithranol theraple.

7.2.4. DISCUSSIE.

Het mechanisme warmee dithranol zijn therapeutisch effect op psoriasiscelien uitoefent is op diverse wijzen in de afgelopen jaren bestudeerd.

Een daling van de mitotische index na dithranol therapie 1 is meermalen beschreven (Krebs \& Schaltegger, 1969; Fry \& McMinn, 1968; Baxter \& Stoughton, 1970; Fry et al. 1974).

Fisher Maibach (1971) vinden daarentegen een stijging van de mitotische index na ditranol applicatie.

steigleder et al. (1973) vinden een normalisatie van de verkorte celcyclustijd en een daling van de labeliling index. Deze daling in antal DNA synthetiserende cellen wordt niet gevonden door Born (1969). Pullmann et al. (1981) vinden, na een aanvankelijke toename van de L.I. in een met dithranol behandelde psoriasislaesie, een daling var de L.I. in de daaropvolgende dagen en weken.

ook over de invloed van dithranol op de duur van de synthesefase heersen uiteenlopende opvattingen. Stelgleder et al. (1973) vinden dat de Ts onder invloed van dithranol korter wordt, terwijl Eisher \& Mabach (1975) een verlenging van deze tijd vinden. Deze tegenstrijdigheden, die weliswaar inherent zijn aan de opvattingen van de diverse auteurs over 
de verschillen in dur van de celcyclus en zijn deelfasen tussen psorlasis en normale epidermis, onderstrepen het gebrek aan kennis van het werkingsmecharisme van dithranol. In de ons bekende literatur hebben we geen onderzoeken met behulp van de flowcytometer naar de therapie-effecten van dithranol kunnen vinden.

Voor de bestudering van het effect van dithranol op het proliferatiepatroon van psoriasiscellen is de methode, waarbij cignoline dagelijks wordt geappliceerd, gekozen boven een Eenmalige lokale toediening. Blj autoradiografisch onderzoek is gebleken dat na een énmalige applicatie van dithranol zeer uiteenlopende en tegenstrijdige waarnemingen werden gedaan (Liden \& Michalesson, 1974). Bij het benadrukken van het fundamentele aspect van het onderzoek naar de therapie-effecten van dithranol zou het juister geweest zijn de eventuele effecten van een éfnmalige toediening te bestuderen. De moellijkheid daarbij is of DNA het enlge aangrijpinspunt van dithranol is. In dit onderzoek is gekozen voor de pragmatische kant van het onderzoek door het effect van dagelijkse applicaties van dithranol na te gaan. Dithranol vormt complexen met DNA leidend tot de inhibitie van de DNA synthese. Het is derhalve te verwachten dat dit zal reflecteren in de parameters die met de flowcytometer worden onderzocht.

Na dagelijkse applicatie van stijgende doses dithranol verschijnt na verloop van tijd in de DNA histogrammen een asymmetrie van de $2 \mathrm{c}$ piek. Het tijdsinterval tussen aanvang van de therapie en het optreden van deze asymetrie, alsook de mate van asymmetrie, is individueel bepaald. Wel is er een relatie tussen het optreden van deze vormverandering en het begin wan de klinische verbetering. Wanneer de klinische verbetering doorzet verdwijnt de asymmetrie geleidelijk.

Asymmetrie van de $2 \mathrm{c}$ piek betekent een toename van het aantal celien dat geregistreerd wordt met een hoeveelheid DNA zoals normaliter cellen in de vroege $S$ fase hebben. Deze schouder in de $2 c$ plek kan reẹel $z i j n, d . w . z$. er is een toename van celien in de vroege $s$ fase, of kan een artefact zijn.

Indien de asymmetrie een gevolg is van een ophoping in de vroege $S$ fase zijn hiervoor in theorle meerder oorzaken denkbaax. De ophoplng kan een gevolg zijn van een synchronisatlegolf. Deze golf moet kunnen worden teruggevonden wanneer ze de celcyclus verder doorloopt. Daar dit in de histogrammen niet gebeurt is deze mogelijkheid hier uitgesloten. ofschoon dithranol de groei van het epitheel irreversibel remt (Klem, 1978), treedt er toch geen totale blokkade op in de vroege $S$ fase. Immers in dat geval moeten de celcylcuscompartimenten achter de blokkade op korte termijn leeglopen. In aanvullend gemaakte DNA histogrammen is echter gebleken dat dit niet geschledt. Een irreversibele blokkade van een deel van de prolifererende cellen geeft histogrammen zoals na toediening van dithranol worden gevonden. Deze mogelijkheid is niet met zekerheid uit te sluiten. Het feit 
dat de asymmetrie verdwijnt bij het voortschrijden van de klinische verbetering is niet in tegenspraak met de mogelijkheid dat dithranol een deel van de prolifererende cellen $11-$ reversibel blokkeert in de vroege $s$ fase. De DNA-dithranol complexen leiden tot stilstand van de DNA replicatie, waardoor de betrokken cellen irreversibel in hun verdere proliferatie worden geremd. Op histologische gronden is het aannemelijk dat deze irreversibel beschadigde cellen door lysis of migratie naar het huidoppervlak verdwijnen. Nadat deze cellen het levend epitheel hebben verlaten neemt de $2 c$ plek in de histogrammen weer de normale vorm aan.

Indien de asymmetrische schouder van de 20 plek op een artefact berust zijn ook in dit geval meerdere mogelijke oorzaken denkbaar. De aanwezigheid van infiltratcellen, die, ofschoon ze diploid zijn, andere kleurelgenschappen hebben dan keratinocyten, kan een dergelijke asymmetrie veroozaken. Dit is onwaarschijnlijk omdat bij histologisch onderzoek geen infiltraat in de epidermis wordt gezien na dithranol applicaties.

Een andere mogelijkheid is dat onder invloed van de dithranol therapie een aantal keratinocyten een afwijkende kleuringskarakteristiek krijgen. In dat geval nelgt de DNA distributie tot verbreding. Uit piek-area experimenten $\mathbb{1}$ s gebleken dat deze afwijkende populatie in de volgens de hier gebruikte wijze verkregen histogrammen grotendeels terecht komt in het gebied van de vroege $s$ fase. ook het ontstaan van cellen met een stabiel RNA, dat niet afbreekt met het hier gebruikte RNA-ase, kan artefacten geven waarbij asymmetrie van de 20 piek ontstaat. Mogelijk dat toepassing van diverse soorten RNA-ase hierin inzicht kan verschaffen.

Bij het uitvergroten van de $4 \mathrm{c}$ piek blijkt dat ook hier een asymmetrie naar de hogere kanaalnummers voorkomt. Deze verbreding kan gezien worden als klontjes van twee cellen met deze afwijkende kleureigenschap. Deze bevinding doet ons ertoe neigen een voorkeur uit te spreken voor de mogelijkheid dat onder invloed van althranol applicaties op de psoriasislaesie een subpopulatie van keratinocyten ontstat die een afwijkende kleuringskarakteristiek hebben. Wanneer deze cellen tijdens de verdere behandeling verdwijnen door lysis of migratie uit de prolifererende pool herkrijgen de histogrammen hun normale vorm.

Het percentage cellen in de $G_{2} M$ fase van de celcyclus wordt volgens onze metingen niet bij alle patierten belnvloed door de dithranol therapie. Bij een aantal personen daalt het aantal tetraploide cellen tot het niveau wan de kilnisch niet aangetaste epidermis. Vele auteurs vinden in histologische coupes een daling van het aantal mitosefiguren na dithranol applicatie. Op grond hiervan zou een geringe daling van de $G_{2} M$ te verwachten $z i j n$. Mogelijk wordt de daling 
in mitose aantal gecompenseerd door verlenging van de duur van de $\mathrm{G}_{2}$ fase, zoals deze met behulp van FLM curves door F"isher \& Malbach (1975) na dithranol therapie is gevonden.

Op grond van de gevonden histogrammen is het aannemelijk dat dithranol een deel van de prolifererende psoriasiscellen uit de prolifererende populatie doet verdwijnen, waarna deze cellen uit het levend epitheel verwijnen.

7.3. FOTOCHEMOTHERAPIE.

7.3.1. INLEIDING.

Het gunstige therapeutische effect van zonlicht op psoriasis is reeds lang bekend. Betere resultaten met ultra violet licht behandeling werden na 1925 verkregen toen Goeckerman de methode beschreef om de werking van u.v. licht te vergroten door de huid te fotosensibiliseren met koolteerzalf. Dit principe is ook met succes toegepast door gebrulk te maken van tryptaflavine (Oppenheim, 1928) en sulfa (Tulipan, 1941; Epstein, 1947). Ook psoralenen zowel lokaal (Walter \& Voorhees, 1973; Mortazawi \& Oberste Lehn, 1973; Weber, 1974) als oraal (Parrish et al.,1974; Swanbeck et al.,1975; Wolff et al.,1975) in combinatie met langgolvig ultra violet licht blijken succesvol bij de behandeling van psorlasis.

In onderstaand capitulum worden met behulp van de flowcytometer de eventuele effecten van behandeling met teerbaden en hoogtezon en met PUVA op de DNA distributie in epidermiscellen uit normale huid en uit psoriasislaesies onderzocht.

7.3.2. GOECKERMAN THERAPIE.

7.3 .2 .1$. INLEIDING.

De Goeckerman theraple, zoals deze bij dit onderzoek is toegepast, bestaat ult het nemen van een teerbad en vervolgens hoogtezon bestraling in stijgende dosering. Deze procedure wordt bij het gebruikelijke therapleregime in de kliniek gecompleteerd door dagelijkse applicatie van dithranol pasta in stijgende concentraties (Ingram therapie). Deze combinatietherapie is nog steeds een van de meest succesvolle bij de behandeling van psoriasis. Daar dithranol, gezien de complicaties die kunnen optreden, alleen door ervaren personen kan worden geappliceerd, kan deze behandeling slechts intramuraal plaatsvinden. De gemiddelde opnameduur bedraagt dan ongeveer 4 weken. Behandeling volgens Goeckerman kan wel poliklinisch worden toegepast. De teerbad-hoogtezon behan- 
deling wordt, teneinde een opname te voorkomen, frequent als adiuvans gebruikt in die gevallen warbij de psoriasis resis tent is tegen de gebruikelijke poliklinische behandelingswijze. Het therapeutisch resultaat van de teerbad-hoogtezon behandeling is wisselend. Als regel wordt de laesie slechts schilfervijj, waarbij nog vaak rode plaques op de huld blijven bestaan (LeVine et a1.,1979).

Het effect van dithranol op de DNA verdeling in de behandelde epidermiscellen is reeds elders (7.2.) vermeld. Met het oog op een optimalisatie van de therapie lijkt het zinvol het effect op de celcyclus van teerbad-hoogtezon behandeling alleen en in combinatie met dithranol applicatie te onderzoeken.

3.2. 2. MATERIAAL EN METHODE.

Bij zes patienten, die reeds jaren 1 ijden an psoriasis vulgaris, is én arm behandeld met teerbad-hoogtzon alleen. op de overige laesies werd tevens dithranol in stijgende concentratie in pasta Lassar geappliceerd. De behandeling bestond uit het nemen van een teerbad $(100 \mathrm{ml}$ liquor carbonis detergens in ongeveer 200 liter water) gedurende 20 minuten gevolgd door hoogtezon bestraling. De duur van deze bestraling bedroeg 1 minuut op de eerste dag; elke volgende dag stijgt de bestralingsdur met 1 minuut totdat een dur van 15 minuten is bereikt. De betraling vond plaats met westinghouse hoogtezonlampen (FS 40W sunlamp). Deze lampen zenden voornamelijk u.v. B licht uit (emissieplek bij $312 \mathrm{~nm}$ ). De behandeling vond klinisch plaats. Geen van de patienten gebruikte medicatie van welke aard dan ook.

Dagelijks zijn monsters voor flowcytometrisch onderzoek afgenomen uit dezelfde psoriasis plaque op linker en rechter arm. De monsters van de klinisch niet aangetaste epidermis zijn genomen uit de arm die alleen Goeckerman therapie had ontvangen. Afname en bewerking van de monsters geschiedde gelijktijdig en onder gelijke condities. Meting van de celsuspensies en anaylse van de histogrammen gebeurde op de wijze zoals beschreven in hoofdstuk 3 .

3.2.3. RESULTATEN.

In de niet aangetaste epidermis treden tijdens de teerbadhoogtezon behandeling geen veranderingen op in het percentage $s$. Het percentage $G_{2} M$ stijgt bij enkele proefpersonen, terwijl bij anderen geen reactie wordt gereglstreerd.

De psoriasislaesies die alleen met teerbad gevolgd door hoogtezon bestraling zijn behandeld vertonen in de loop van de behandeling geen tot een geringe daling van het percentage $S$. De $G_{2} M$ fractie ondergaat geen duidelijke verandering. Er ontstaat geen asymmetrie van de $2 \mathrm{c}$ piek in tegensteliing tot de 
laesies die anvullend met dithranol zijn behandeld. De daling van het percentage $S$, die in de volgens Ingram behandelde laesies optreedt, is veel groter dan in de laesie die alleen teerbad en hoogtezon bestraling hebben ontwangen. Het percentage $G_{2} M$ ondergaat ook tijdens de Ingram therapie sechts geringe verandering. Tabel 7.3.1. geeft de gevonden warden weer voor én aldus behandelde persoon.

Tabel 7.3 .1 .

$T$ Niet angetaste epidermis
Teerbad + Hoogtezon laesie
Ingram laesie

$$
\mathrm{G}_{2} \mathrm{M}
$$

$S$

$G_{2} M$

\begin{tabular}{lcccccc}
\hline 0 & 4,3 & 1,8 & 8,2 & 3,0 & 8,4 & 2,9 \\
1 & 4,1 & 1,7 & 8,7 & 3,2 & 8,0 & 3,0 \\
2 & 4,4 & 2,0 & 8,6 & 2,6 & 9,0 & 2,8 \\
3 & 4,4 & 1,9 & 7,8 & 2,7 & 7,4 & 2,5 \\
4 & 3,8 & 1,6 & 8,6 & 3,1 & 7,6 & 2,8 \\
5 & 4,0 & 2,1 & 8,8 & 3,2 & - & - \\
7 & 4,2 & 1,9 & 7,8 & 2,9 & 7,0 & 3,0 \\
8 & 4,0 & 1,7 & 7,9 & 2,8 & 7,3 & 2,7 \\
9 & 4,2 & 2,0 & 8,0 & 3,2 & 6,4 & 2,8 \\
10 & - & - & - & - & 6,0 & 2,7 \\
\hline
\end{tabular}

Tabe1 7.3.1.: Overzicht van de DNA verdelingen in procenten in het verloop van de $t i j d$ ( $T$ in dagenl na behandeling van niet aangetaste epidermis en psoriaslslaesie met teerbad en hoogtezon bestraling en van psoriasislaesie behandeld volgens Ingram bij ëen persoon.

7.3.2.4. DISCUSSIE.

Ultraviolet bestraling in combinatie met koolteer voorbehandeling is een therapeutisch regime geweest gedurende vele jaren. Vele psoriasispatienten ervaren het nemen van een teerbad echter als een minder prettige ervaring.

Hoogtezonbestraling van met teer gefotosensibiliseerde epidermiscellen uit een psoriasislaesie heeft geen grote veranderingen in de DNA verdeling in de epidermiscelien tot gevolg. Hiermee in overeenstemming is onze klinische ervaring 
dat Goeckerman therapie de psoriasislaesie niet doet verdwijnen. De laesie wordt als regel slechts schilfervrij. Fischer (1976) vermeldt dat u.v. energie van $313 \mathrm{~mm}$ psoriasislaesies kan aanzetten tot genezing. Levine et al. (1980) tonen daarentegen aan dat, ook indien de laesies klinisch zijn verdwenen, het extractiepatroon van de keratineproteinen van de epidermis kenmerkend voor psoriasis blijft. Eveneens is er geen complete resolutie van de abnormale histologische en histochemische bevindingen zals deze bij psoriasis worden gezien (Frank et al. 1964: Lawler \& Vineyard, $1960)$.

De door Epstein et a1. (1970) gevonden remming van de proIiferatieactiviteit na Goeckerman therapie wordt door onze metingen niet bevestigd. Het wargenomen verdwijnen van de schilfers berust volgens onze metingen niet op een verminderde delingsactiviteit van de psoriasiscellen. Veeleer is het effect van deze therapie meer cosmetisch dan reêlel.

Uit de histogrammen blijkt dat het celkinetisch effect pas optreedt wanneer dithranol an de therapie wordt toegevoegd. Flowcytometisch zijn er duidelijke verschillen tussen behandeling met en zonder dithranol applicatie na Goeckerman therapie.

Klinisch ontstaat na een behandelingsduur van ongeveer een week bij de meeste patienten een duidelijk waarneembaar verschil tussen laesies die op deze belde manieren zijn behandeld. De gevonden verschilien in percentage $s$ lopen parallel met de verschillen in klinisch beeld. Ook in deze proefnemingen bestaat een correlatie tussen het verschijnen van de asymmetrie van de $2 c$ piek in de histogrammen van met dithranol behandelde laesies en het begin van de klinische verbetering van deze laesies.

Volgens Ingram (1953) biedt de combinatie van teer, u.v. licht en dithranol voordelen. Met deze methode berelkte Comaish (1965) bij klinisch behandelde psoriasispatienten bij een gemiddelde therapleduur van 15,2 dagen bij 95 van de patienten een volledig verdwijnen van de laesles. We $1 \mathrm{ke}$ rol dithranol en $u . v$. licht in deze behandelingsketen spelen is nog geenszins duidelijk. Er bestaan experimentele en kilnische aanwijzingen dat $u . v$. licht het therapeutisch effect van dithranol kan verhogen (Dugois et ad., 1975: Walter et al.,1978). Schauder \& Mahrle (1982) kunnen daarentegen geen beter therapileresultaat voor deze combinatietheraple aantonen.

Aan de therapeutische rol van teer in de combinatie met $u$. $v$. bestraling wordt door meerdere auteurs getwijfeld (Levine Parrish,1980; Belsito \& Kechijian,1982).

Schauder \& Mahrle (1982) kunnen geen verbetering van de dithranolwerking op psoriasislaesies door u.v. B bestraling vaststellen. Dit stemt overeen met onze bevindingen.

Het percentage $G_{2} M$ daalt tijdens de Ingram behandeling 
nawwelijks, in tegenstelling tot de verwachting. Psoriasiscellen die alleen met cignoline zijn behandeld vertonen deze daling tijdens de behandeling wel. Van belichting met u. $v$. B licht is bekend dat deze een toename van de G2M fractie geeft (Mier et a., 1977 ). Het is mogelijk dat de bij de met de Ingram theraple geinduceerde genezing verwachte daling wordt gecamoufleerd door deze toename van $\mathrm{G}_{2} \mathrm{M}$.

Het is de vraag of bij de behandeling met dithranol voorbehandeling met teerbad en hoogtezonbestraling noodzakelijk is. Aan de therapeutische rol van teer wordt door velen getwijfeld, terwijl schauder \& Mahrle (1982) geen verbetering van de dithranolwerking door $u$. v. B bestraling hebben kumnen aantonen. Zowel de histogrammen van psoriasiscellen afkomstig uit laesies die alleen met dithranol zijn behandeld (cf. 7.2.), alsook de histogrammen van psoriasiscellen die tevens teerbad en hoogtezonbestraling hebben ontvangen (totale Ingram behandeling) vertonen belde dezelfae trend wat betreft daling van het percentage $s$ en asymmetrie van de $2 \mathrm{c}$ plek. De tijd die verloopt tussen aanvang van de therapie en het optreden van de voorbijgaande asymmetrie van de $2 \mathrm{c}$ plek is individueel bepaald. Derhalve dient bij het doen van een uitspraak over het al dan miet leveren van een bijdrage van de teerbad-hoogtezon component aan het therapeutisch succes en de snelheid warmee dit succes optreedt voorzichtigheid te worden betracht gezien het feit dat hier siechts een gering aantal personen is onderzocht. De verkregen resultaten maken een uitgebreider klinisch en flowcytometrisch onderzoek natar deze vraagstelling gewenst, temeer daar recente publicaties een keerpunt in deze reeds tientallen jaren bestaande behandelingswijze lijken in te luiden, hetgeen zeker door vele patienten als angenaam zal worden ervaren.

3.3. PUVA.

7.3.3.1. INLEIDING.

Onder PUVA behandeling verstaat men de combinatie van een psoraleen preparaat (P) en bestraling met ultra violet $A$ (UVA) 1lcht (320-400 nm). Onder belichting met het lang golvige u.v. licht intercaleren de geëxciteerde furocoumarines met de pyrimidine basen van nucleinezuren door hiermee een covalente binding aan te gaan (Musajo et al.,1967; Pathak \& Kramer, 1969; Rodighiero et al.,1970). Deze fotochemische reactile leidt tot meerdere typen foto-producten, afhankelijk van het furocoumarine derivaat (Dall'Acqua et al.,1971). De moleculaire structuur van de diverse furocoumarine derivaten en de stereometrische relatie met de pyrimidine basen, wanneer $z i j$ geintercaleerd worden in het DNA, $z i j n$ bepalend voor de mate waarin dwarsbruggen worden gevormd tussen de twee strands van de DNA dubbel helix (Cole,1970; Dall.'Acqua et al.,1971; Musajo \& Rodighiero,1972). Deze dwarsbruggen 
kunnen met het electronenmicroscoop zichtbaar worden gemaakt en worden gekwantificeerd (Lerche et al. "1979).

De vorming van foto-adducten van psoraleen en pyrimidines leidt mogelijk tot inhibitie van de DNA synthese. Deze inhibitie van de epidermale DNA synthese is de rationele achtergrond voor het gebruik van psoralenen bij de behande$11 n g$ van psoriasis (Parrish et al. 1974).

Het doel van dit onderzoek is met behulp van de flowcytometer na te gaan of en zo ja op welke wijze PUVA behandeling de epidermale celkinetiek bij psoriasis beinvloedt.

\subsubsection{MATERIAAL EN METHODE.}

Het effect van een eénmalige PUVA behandeling op een normale epidermis is bepaald. Hiervoor werden twee personen zonder psoriasis, bij wie tevens de familieanamnese voor psoriasis negatief was, énmalig bestraald met een hoeveelheid UVA licht (Waldmann 6000 PUVA apparat), die in overeensteming was met de minimale erytheem dosis (M.E.D.) twee ur na orale toediening van 8-Methoxypsoraleen (8-MOP). De hoeveelheid 8-MOP werd bepaald door het lichaamsgewicht van de proefpersonen.

Vervolgens zijn de veranderingen in de DNA distributie in de epidermiscellen tengevolge van PUVA therapie bepaald bij twaalf personen met een psoriasis palmaris. Deze onderzochte groep patienten, die op de polikliniek is gerecruteerd, is gedurende het gehele onderzoek klinisch behandeld. Veertien dagen voor en tijdens het gehele onderzoek hebben $z i j$ geen locale of systemische therapie van andere aard gekregen.

Het bij dit onderzoek gebruikte furocoumarine derivat is het 8-Methoxypsoraleen (Meladinine, 30-50 mg per os, afhankelijk van het lichaamsgewicht). De lichtbestraling vond twee uur na de inname plaats. De UVA belichting geschiedde met een Waldmann 200 PUVA apparaat (emissile piek $365 \mathrm{~nm}$ ). De begindosis van de bestraling was gelijk aan de minimale erytheem dosis, de verhoging van het aantal Joules/cm was overeenkomstig de phototoxische pigmentatie index (P.P.I.). De psoriasislaesies werden viermaal per week behandeld. Dagelijks werden monsters uit laesie en normaal uitziende huid voor flowcytometrisch onderzoek afgenomen. Het afnametijdstip was steeds 1 uur na de belichting.

Tevens is bij acht van de bovengenoemde psoriasispatienten het effect van 8-MOP alleen en 8-MOP In combinatie met UVA nagegaan voor de k.linisch normale huld. Deze monsters werden afgenomen op een tijdstip dat de histogrammen van cellen uit de psoriasislaesies duidelijke veranderingen ver- 
toonden.

Aframe, bewerking en meten van monsters van dezelfide patient geschiedden gelijktijdig en onder gelijke condities op de in hoofastuk 3 beschreven wijze.

Tenslotte zijn de eventuele verschillen in DNA distributies van celpopulaties afkomstig uit klinisch nomale huid die de volle belichting met UVA had ontvangen en uit de klinisch normale huld die slechts zijdelings was "meebelicht" onderzocht. De verschillen in hoeveelheid opgestraald UVA Iicht tussen beide plaatsen op de huid konden met een belichtingsmeter goed zichtbaar worden gemaakt. Door de grote individuele verschilien in de volgens het behandelingsschema benoagde hoeveelheid UVA licht op grond van de sterk witeenlopende P.P.I.'s, was het niet goed mogelijk deze verschillen te kwantificeren. Ook deze monsters zijn gelijktijdig afgenomen, bewerkt en gemeten op de in hoofastuk drie beschreven wijze.

7. 3.3.3. RESULTATEN.

Eénmalige PUVA behandeling van normale epidermiscelien.

Een énmalige PUVA behandeling van een normale epidermis met een lichtdosis gelijk aan de M.E.D. geeft een stijging van de $4 \mathrm{c}$ piek te zien (tabel 7.3.2.).

Tabe1 7.3 .2 .

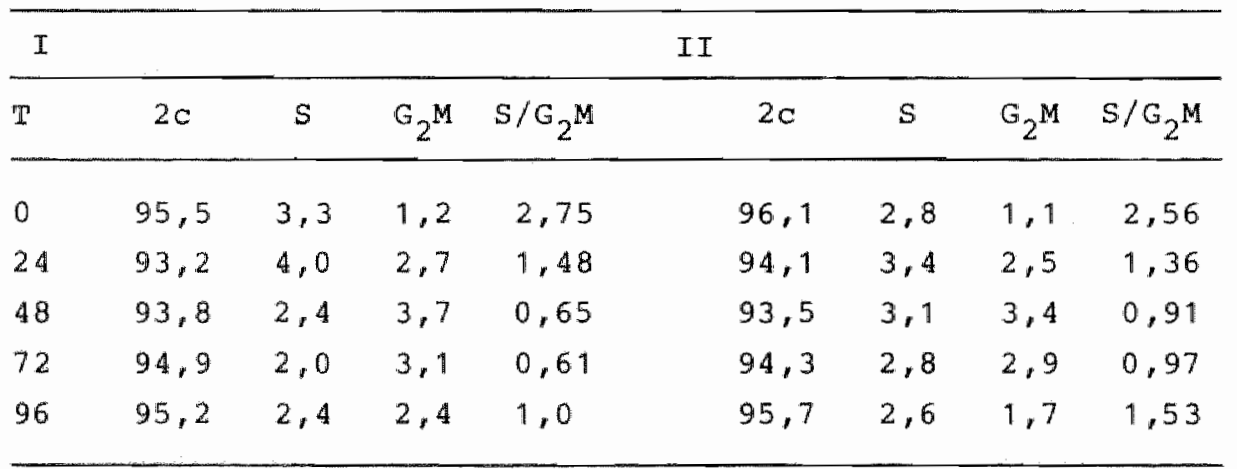

Tabel 7.3.2.: Overzicht van de analyses van de DNA verdelingen in normale epidermiscellen na een éénmalige PuVA behandeling met een dosis gelijk aan de M.E.D. bij twee gezonde proefpersonen in relatie tot de tijd (uren). 
KIinisch niet aangetaste epidermis bij personen met psoriasis.

Blj 8 psoriasispatienten zijn, op een tijdstip dat de histogrammen van cellen uit met PUVA behandelde lavesies duidelijke veranderingen vertoonden, de DNA verdeling in klinisch normal uitziende epidermis bepaald. Bij allen blijkt 8-MOP alleen geen stijging van de $G_{2} M$ fractie te geven. Deze stijging treedt pas op bij de combinatie 8-MOP en UVA 1 icht. De ratlo $\mathrm{S} / \mathrm{G}_{2} \mathrm{M}$ daalt dientengevolge a anmerkelijk.

Tabel 7.3.3. geeft de gevonden waralen voor de ratio $\mathrm{s} / \mathrm{G}_{2} \mathrm{M}$ weer.

Tabe1 7.3 .3 .

$$
\text { 8-MOP alleen } 8-M O P+U V A
$$

Pat no Ratio $\mathrm{S} / \mathrm{G}_{2} \mathrm{M} \quad$ Ratio $\mathrm{S} / \mathrm{G}_{2} \mathrm{M}$

Tabel 7.3.3.: Toont de ratio $\mathrm{S} / \mathrm{G}_{2} \mathrm{M}$ van klinisch niet aangetaste epidermis bij 8 psoriasispatienten die verscheidene malen 8-methoxypsoraleen alleen en 8-methoxypsoraleen in combinatie met UVA bestraling hebben ontvangen op een tijastip dat de histogrammen van cellen uit de met PuvA behandelde psorastslaesies duldelijke veranderingen vertoonden.

De stijging van de $4 \mathrm{c}$ piek geschiedt pas als de combinatie 8-MOP en UVA wordt toegepast. Tabel 7.3.4. geeft aan dat de mate van toename van de $4 \mathrm{c}$ piek is gerelateerd aan de dosis opvallend UVA licht. 
Tabe 17.3 .4 .

geen
UVA
Partiele

belichting
Volle

belichting
5
$\mathrm{G}_{2} \mathrm{M}$
$s / G_{2} M \quad s$
$\mathrm{G}_{2} \mathrm{M}$
$S / G_{2} M$
S $\quad G_{2} M$
$\mathrm{S} / \mathrm{G}_{2} \mathrm{M}$

\begin{tabular}{llllllllll}
1 & 3,9 & 1,8 & 2,17 & 4,5 & 2,7 & 1,67 & 4,4 & 4,0 & 1,10 \\
2 & 3,6 & 1,2 & 3,00 & 4,2 & 2,8 & 1,50 & 5,4 & 4,9 & 1,10 \\
3 & 3,6 & 1,7 & 3,82 & 3,8 & 2,3 & 1,22 & 5,3 & 4,3 & 1,23 \\
\hline
\end{tabular}

Tabe 1 7.3.4.: Geeft de DNA distributie in de cellen uit klinisch normale epidermis van drie psoriasispatienten die, in combinatie met 8-MOP, geen, resp. partiële, resp. volle UVA belichting hebben ontvangen.

Psoriasis.

Bij 10 van de 12 patienten met palmaire psoriasis treedt, na een individueel sterk wisselende tijd, variërend van enkele dagen tot twee weken, een zeer sterke stijging van het percentage $\mathrm{G}_{2} \mathrm{M}$ op (fig. 7.3.1. tabel 7.3.5.). Het percentage $G_{2} M$ kan stijgen tot boven de $20 \%$. Ondanks het feit dat de PUVA therapie wordt gecontinueerd, $z i j$ het bij verbeteren van het klinisch beeld in een lagere frequentie, daalt het percentage $\mathrm{G}_{2} \mathrm{M}$ weer (fig. 7.3.2.).

Tegelijkertijd treedt in het algemeen een relatief geringe daling van het percentage $s$ op. Dit percentage blijft langdurig, ook wanneer de behandelde psoriasisplek reeds lang weer klinisch normal uitziet en de PUVA behandeling is gestopt, op een hoog nlveau (fig. 7.3.3.). De ratio $5 / G_{2}$ daal, door de sterke stijging van $G_{2} M$, in een individuee 1 sterk wisselend tijasbestek.

Het kilnisch resultaat is bij 10 patienten goed, d.w.z. dat de psorlasislaesie klinisch is verawenen, bij twee patienten treedt echter snel een recidief op. Twee patienten reageerdem noch klinisch, noch flowcytometrisch op de PUVA therapie (tabe 1 7.3.5.). 
Tabe $\mathbb{1} 7 \cdot 3 \cdot 5$.

$\begin{aligned} \text { No } M / V & \text { Leeftijd Begin stij- Begin kli- Kiinisch eind- } \\ \text { ging } G_{2} M & \text { nisch effect resultat }\end{aligned}$

\begin{tabular}{lllccl}
1 & $M$ & 52 & 2 & 2 & goed \\
2 & $\mathrm{~V}$ & 21 & 10 & 5 & goed, snel rec. \\
3 & $\mathrm{M}$ & 50 & geen & geen & geen effect \\
4 & $\mathrm{M}$ & 37 & 7 & 7 & goed \\
5 & $\mathrm{M}$ & 47 & 6 & 10 & erytheem rest \\
6 & $\mathrm{M}$ & 47 & 14 & 19 & goed \\
7 & $\mathrm{M}$ & 67 & geen & geen & geen effect \\
8 & $\mathrm{M}$ & 17 & 3 & 3 & goed \\
9 & $\mathrm{~V}$ & 57 & 13 & 12 & goed \\
10 & $\mathrm{M}$ & 28 & 3 & 5 & goed \\
11 & $\mathrm{~V}$ & 31 & 10 & 9 & goed \\
12 & $\mathrm{M}$ & 80 & 2 & 4 & goed, snel rec. \\
\hline
\end{tabular}

Tabe1 7.3.5.: Geeft voor de met PUVA beharidelde patienten met palmaire psoriasis het eindresultaat van de behandeling weer, alsmede de tijdsintervallen in dagen tussen aanvang van de therapie en het begin van de stijging van de $4 \mathrm{c}$ piek en resp , het begin van het klinisch effect. 
E19. $7 \cdot 3 \cdot 1$.

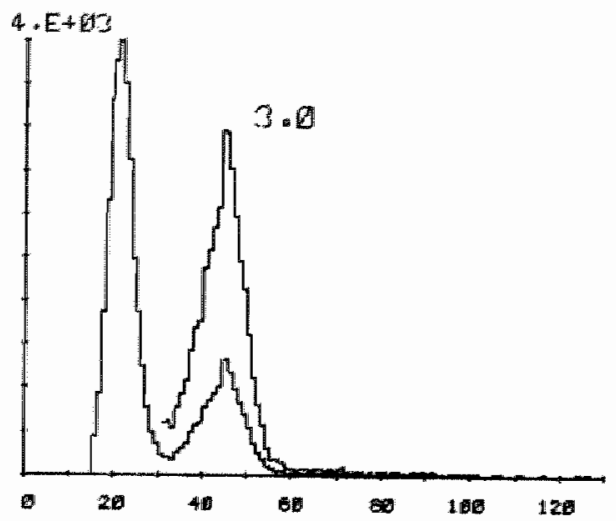

F19. 7.3.1.: toont de zeer sterke toename van de $4 \mathrm{c}$ piek in het DNA histogram van cellen uit een psoriasislaesie die meermalen met PUVA is behandeld.

Fig. 7.3 .2 .

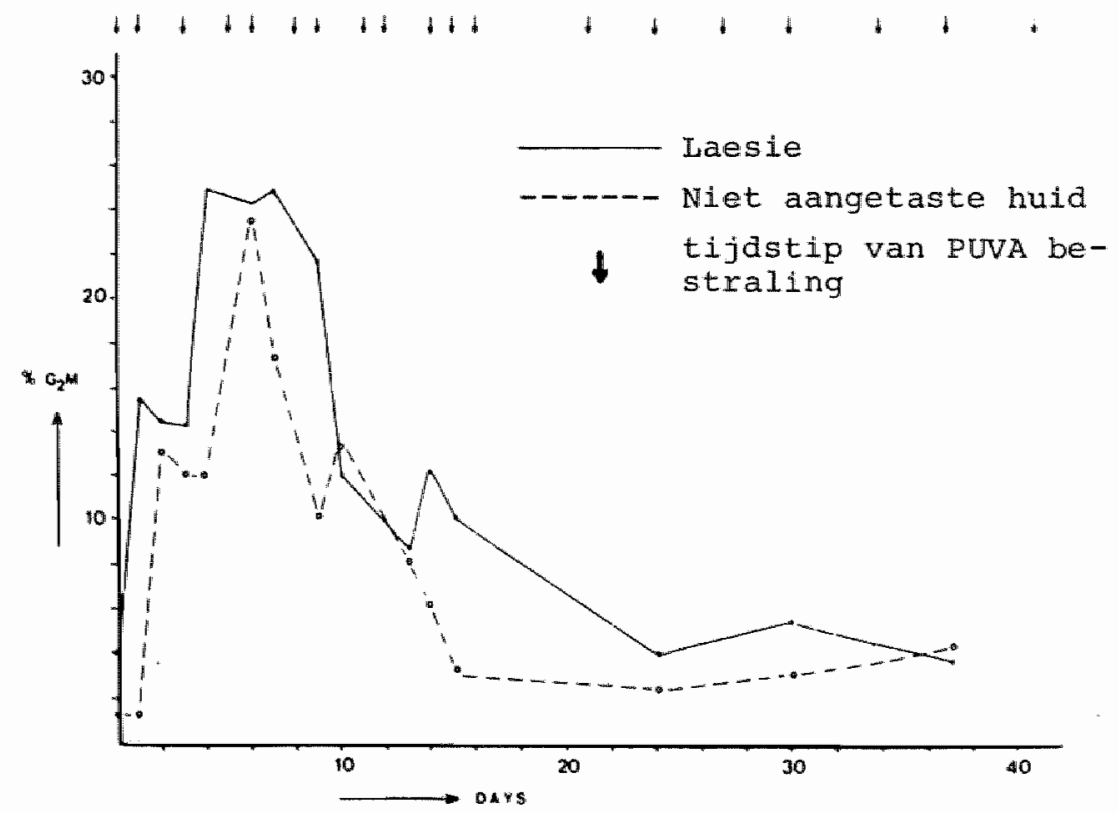

Fig. 7.3.2. : Toename en afname van het percentage $G_{2} M$ in de DNA histogrammen van cellen uit psoriasislaesie en niet aangetaste epidermis na PUVA behan-deling. 
Fig. $7 \cdot 3 \cdot 3$.

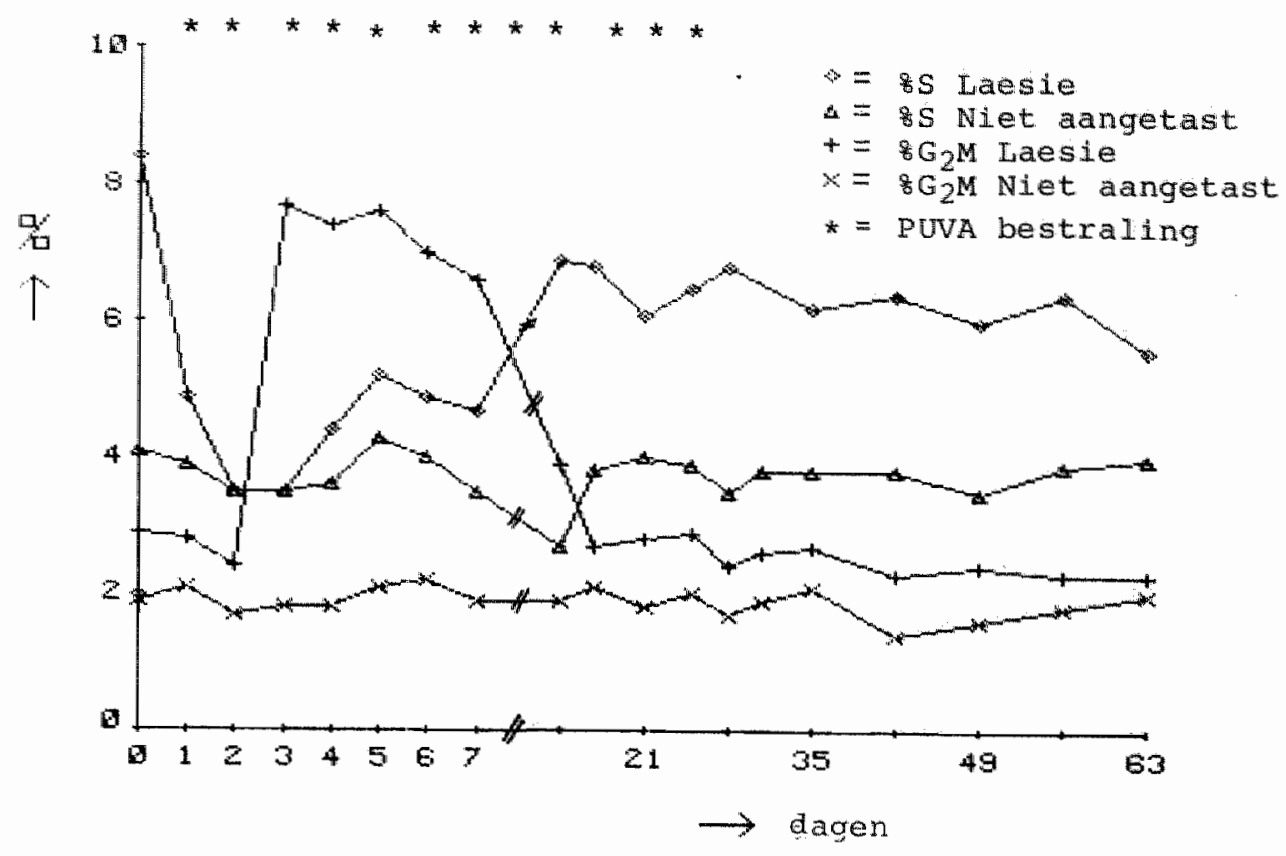

Fig. 7.3.3.: overzlcht van het verloop van de percentages $S$ en $G_{2} M$ in DNA histogrammen van celsuspensies uit meE PUVA behandelde psoriasislaesies en uit klinisch niet aangetaste epidermis, die geen behandeling heeft gekregen, bij én psoriasispatient in het verloop van de tijd.

3. 4. DISCUSSIE.

Sinds Parrish et al. (1974) over de succesvolle behandeling van psoriasis met B-MOP en UVA stralen berichtten, heeft PUVA therapie zich een belangrijke plaats verworven bij de behandeling van psoriasis (Wolff et a.l., 1981). PuVA behandeling heeft ondermeer inhibitie van de celproliferatie tot gevolg (Kenicer et al.,1981), waarbij momenteel nog niet met zekerheid bekend is of de inhibitie van de DMA synthese een direct gevolg van DNA beschadiging is of het resultaat. van effecten in andere systemen (Bishop \& Gray,1981).

Uit de resultaten van de hier verrlchte metingen kan worden geconcludeerd dat de flowcytometrische methode gevoelig gemoeg is om subtiele veranderingen in DNA distributie tijdens de behandeling van de epidermis met PUVA te registreren. Bovendien geeft zij nieuwe informatie die autoradiografische 
methoden niet bieden.

Een Eennalige Puva behandeling van een normale epidemis geeft een voorbijgande sterke stijging van de Gy fractie. De $s$ fractie lijkt kortdurend enige stijging te ondergaan. ook klinisch niet aangetaste huid bij personen met psoriasis vertoont een stijging van de $\mathrm{G}_{2} \mathrm{M}$ fractie. 8-Mop alleen geeft geen toename van de $4 \mathrm{c}$ piek. De mate van stijging van de $4 c$ plek in de histogrammer van cellen uit klinisch normale hula lijkt bij de individuele patient afhankelijk van de hoever lheid Joules $/ \mathrm{cm}^{2}$ die op de epidermis valt. Dit is in overeensteming met de bevindingen van kräger et al. (1978) dat de mate van fototoxiciteit voornamelijk afhanke1 ljk is van de dosis UVA.

Na een individueel bepaalde tijd na aanvang van PUVA behandeling van psoriasiscellen treedt een weer sterke stijging van de $G_{2} M$ fractie op. ondanks continueren van de PUVA theraple daalt het percentage $G_{2} M$ vervolgens weer.

De sterke toename van de $G_{2} M$ fractie betekent een ophoping van cellen in de $G_{2}$ fase. Dat late $S$ cellen een bijdrage aan de $4 \mathrm{c}$ piek leveren kan niet worden uitgesloten. De zich in de $G_{2}$ fase ophopende cellen $z i j n$ afkomstig uit de $S$ fase. Omdat de $S$ fase uiteindelijk niet leegloopt kan ex geen sprake zijn van een totaal irreversibel blok in de $G_{2}$ fase. Wel kan de tijdelijke toename verklaard worden door het felt dat een deel van de proliferende cellen irreversibel in de $\mathrm{G}_{2}$ fase wordt geblokkeerd. De wargenomen daling van de $G_{2} M$ plek wordt vervolgens veroorzaakt doordat de geblokkeerde celien uit de populatie worden verwijderd door lysis of migratie naar het huidoppervlak. Het therapeutisch effect van de PUVA behandeling op de prolifererende celpopulatie in een psoriasisepidermis bestaat kennelijk uit elimininatie van een aantal cellen uit deze populatie en wel. In de $\mathrm{G}_{2}$ fase van de celcyclus.

ondanks het contimueren van de pUVA behandelingen treedt na de daling van de $G_{2}$ iractie niet opnieuw een stijging op. De oorzaak hiervan is ons niet duidelijk. Mogelijk dat het repair mechanisme, dat door meerdere auteurs na PUVA behandeling $1 \mathrm{~s}$ a angetoond (Lata et al.,1981; Honigsmann et a1. 1981), door enzyminductie beter functioneert.

Het percentage $S$ in de laesie daalt slechts langzaam en biljft ook in de klinisch weer normal uitziende huid relatief hoog. Ook in de belichte niet aangetaste huid is dit percentage verhoogd. Het effect van PUVA behandeling van de proliferende celpopulatie is wat de $s$ fractie betreft soms nog tot 40 dagen na de laatste PUVA behandeling nog aantoonbaar.

op grond van de optredende verbetering in klinisch beeld is een daling van het percentage s te verwachten. Deze daling treedt wel op, max is vrij gering. Uit figuur 7.3.3. blijkt dat de ratio $S / G_{2} M$ in de voormalige laesie groter is dan die 
in de overige niet aangetaste epidermis. Hieruit kan geconcludeerd worden dat de relatieve duur van de $s$ fase langer wordt. Eien verlenging van de $s$ fase duur resulteert in de flowcytometrische metingen in een hoger percentage $\mathrm{s}$. Bij autoradiografisch onderzoek wordt een toename van de incorporatie van gemerkt thymidine in met PUVA behandelde monsters gevonden, welke wordt toegeschreven aan repair mechanismen in door PUVA beschadigd DNA (Epstein \& Fukama, 1975; Lata et al.,1981). Met de flowcytometer worden deze herstelwerkzaamheden aan het DNA nilet gemeten, daar de cellen waarin het DNA wordt hersteld een $2 \mathrm{c}$ hoeveelheid DNA blijven bevatten.

over het verhoogde percentage s kan met behulp van de flowcytometer geen zekere uitsprak worden gedaan omdat bij deze methode de hoeveelheid DNA per cel wordt gemeten en niet de syntheseactiviteit.

De ophoping van cellen in de $G_{2}$ fase treedt blijkbaar pas op wanneer een individueel bepalde drempel is overschreden. ofschoon er een duidelijke correlatie is tussen de toename van het percentage $\mathrm{G}_{2} \mathrm{M}$ in de histogrammen en de klinische verbetering, kam de doelstelling dat in het histogram van te voren de te verwachten klinische verbetering kan worden waargenomen en voorspeld, niet worden bereikt.

De laatste tijd bestaat er discussie of PUVA therapie rechtstreeks in de epidermis aangrijpt of via andere systemen werkt. De ophoping van cellen in de $G_{2}$ fase wijst op een directe beschadiging van de prolifererende keratinocyten door PUVA, hetgeen niet uitsluit dat PUVA ook aangrijpingspunten in andere systemen, b.v. het immunologische systeem heeft. Dit kan met de hier gebruikte methode niet worden opgehelderd. 
7.4.1. INLEIDING.

In het verleden is röntgenbestraling, vaak in sterk uiteenlopende doses, frequent toegepast bij de behandeling van psoriasis. De latste jaren wordt deze therapie in toenemende mate gereserveerd voor hardnekkige plaques die geenzins op de normale therapie reageren (Braun-Falco \& Lukacs,1973; Röntgencomuissie NVVD, 1976).

Empirisch 1 s gebleken dat $100 \mathrm{R}$, drie doses met tussenpausen van een week, een gunstig therapeutisch resultaat hebben. De absorptie van röngenstralen in een parakeratot 1 sche psoriasis hoornlaag is groter dan in een normale hoornlaag zodat de reststraling onder het niveau van de epidermis bij psortasislaesies $k$ leiner is dan onder normale epidermis (Steigleder \& Raab,1962). De gevaren van röntgenbehandeling van benigne dermatosen zijn gering en in de moderne dermatologie geaccepteerd mits aan een aantal voorwaarden wordt voldaan (Goldschmidt, 1978).

7.4.2. MATERIAAL EN METhode.

Bij vijf personen, allen mannen, is een geisoleerde handpalmgrote psoriasis vulgaris plek op romp of arm bestraald. De dosis per bestraling bedroeg $100 \mathrm{R} 130 \mathrm{KV}, 0,30 \mathrm{Al}$, FHA: $30 \mathrm{~cm})$. Bij twee personen is deze bestraling na 1 en 2 weken herhaald. Bij 2 patienten vond herhaling na 1 en 3 weken plaats, terwijl bij de laatste patient deze therapie werd herhaald op het tijdstip waarop het percentage $G_{2} M$ weex de uitgangswaarde had bereikt. De omgevende huid is met lood afgedekt. Alle patienten waren onder klinische behandeling voor hun psoriasis. Op de overige psoriasislaesies werd cignoline pasta in stijgende concentraties geappliceerd. Op de gelsoleerde bestraalde psoriasisplek alsmede op de naaste ongeving is geen lokale therapie toegepast. Geen van de patienten had orale of parenterale medicamenten. De bestraling vond plaats met een Philips RT-100 Röntgenapparaat. Het voltage, het fllter en de FHA zljn zodanig gekozen dat meer dan 908 van de straling nog aanwezig is ter hoogte van de basaalmembraan, terwijl op $10 \mathrm{~mm}$ onder het huidoppervlak nog 5 lechts ongeveer 208 van de straling resteert.

Dagelijks zijn monsters voor flowcytometrisch onderzoek volgens de standaardmethode afgenomen. De proliferatiepatronen van de biopten zijn op de in hoofdstuk 3 beschreven wijze bepaala. 
In de DNA histogrammen van op bovengenoemde wijze bestraalde psoriasiscellen treedt bij alle onderzochte patienten een snelle stijging van het percentage $G_{2} \mathrm{M}$ op. Na 3-4 dagen wordt een maximum bereikt waarna het percentage in enkele dagen weer daalt tot de uitgangswaarde. Fig. 7.4.1. toont een voorbeeld van deze toename en afname van $\mathrm{G}_{2} \mathrm{M}$ fase cellen in de DNA histogrammen na röntgenbestraling.

Het percentage $G_{2} M$ fase cellen in de DNA histogrammen van epidermiscellen afkomstig uit een met dithranol behandelde psoriasislaesie, alsmede uit de klinisch normale huid, die geen behandeling heeft ondergaan, vertoont geen reactie op de bestraling (fig. 7.4.2.).

Fig. 7.4.2.:

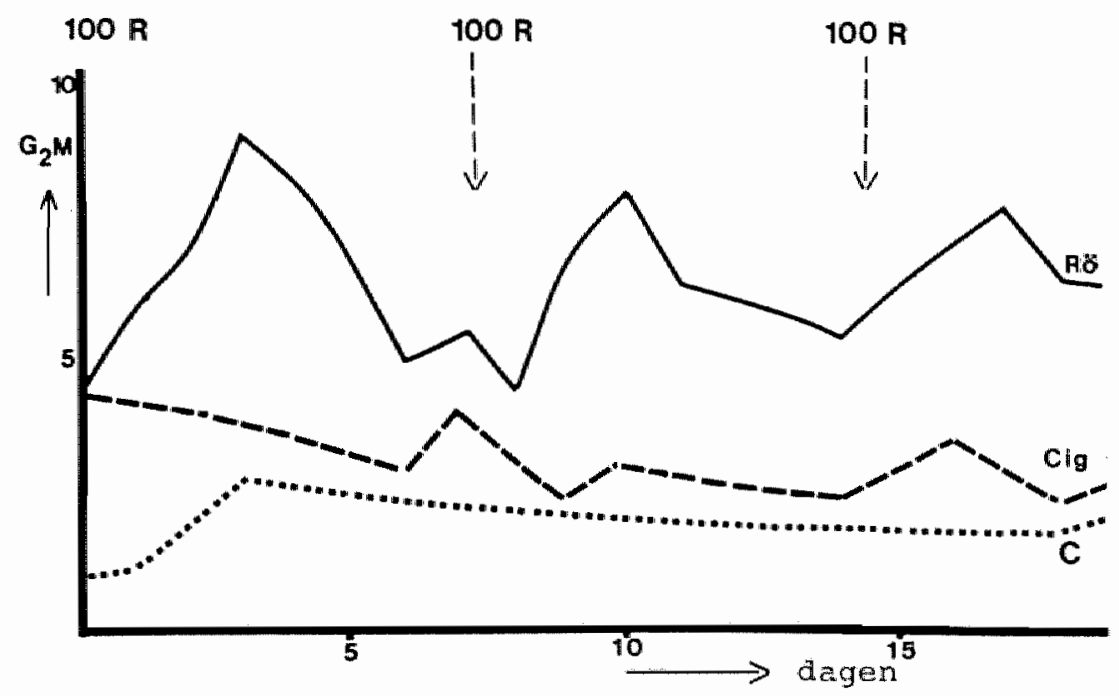

Fig. 7.4.2.: De percentages cellen in de $G_{2} M$ fase in de DNA histogrammen na röntgenbestraling (RÖ) $(100 \mathrm{R}, 0,30 \mathrm{Al}, 30 \mathrm{KV}, 30 \mathrm{~cm} F \mathrm{FA})$, dithranol applicatie (cignoline in stijgende concentraties) (cig) en van klinisch niet aangetaste epidermis (c).

Synchroom met de toename van het aantal $G_{2} M$ fase cellen ontstaat in de DNA histogrammen een sterke daling van het aantal $S$ fase cellen. Het percentage $S$ bereikt een minimum wanneer $G_{2} \mathrm{M}$ maximaal is en stijgt daarna weer geleidelijk tot de uitgangswaarde (fig. 7.4.3.). 
19. 7.4 .1$.
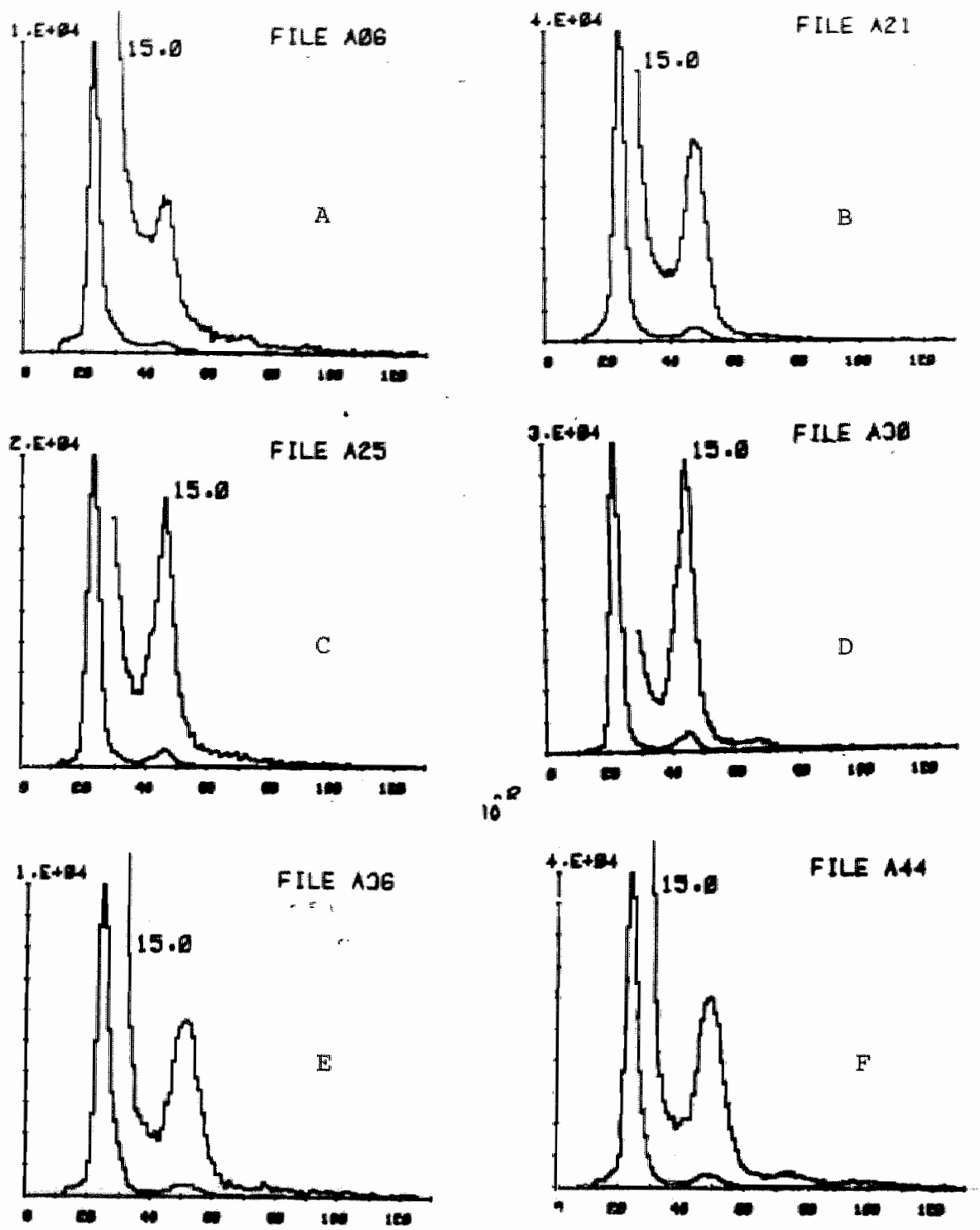

Fig. 7.4.1.: Karakteristilek voorbeeld van de toename en de daaropvolgende afname van de $G_{2} M$ fractie van met rontgenbestraling behandelde psoriasiscellen in het verloop van de tijd. $A: T=0 ; B:$ $T=24$ uur; $C: T=48$ uur; $\mathrm{D}: \mathrm{T}=72$ uur; $\mathbb{E}: T=144$ uur; $F: T=168$ uur na bestraling met $100 \mathrm{R}, 30 \mathrm{KV}, 0,30 \mathrm{Al}, \mathrm{FHA}: 30 \mathrm{~cm}$. 
Fig. 7.4.3.

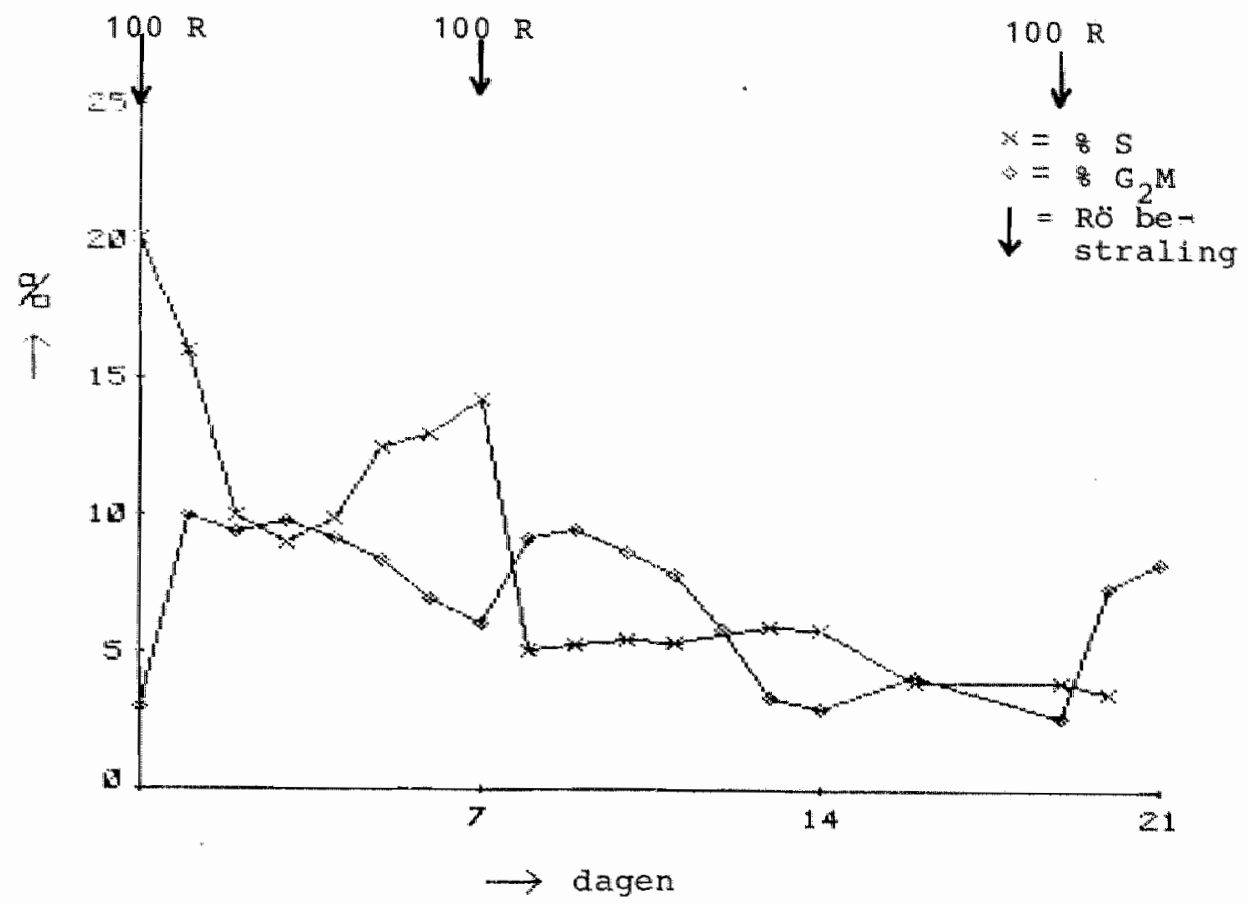

Eig. 7.4.3.: Overzicht van het verloop van de percentages $S$ en $G_{2} M$ in de DNA histogrammen in het verloop van de tijd na bestraling met $100 \mathrm{R}(30 \mathrm{KV}$, $0,30 \mathrm{Al}, \mathrm{FHA}: 30 \mathrm{~cm}$ ).

Een tweede röntgenbestraling geeft opnieuw deze effecten. $\mathrm{Na}$ enkele bestralingen stijgt het pexcentage s niet meer on uiteindelijke een niveau te bereiken van kinisch niet aangetaste epidermis bij psoriasis.

Het tijdsinterval dat nodig is om de $G_{2} M$ fractie weer de uitgangswaarde te laten aannemen lijkt na elke bestraling toe te nemen (fig. 7.4.4.).

In de klinisch niet aangetaste, niet behandelde huid worden geen veranderingen in percentage $S$ en $G_{2} M$ wargenomen. Een vrijwel uniform patroon wordt bij alie onderzochte patienten gezien, zij het dat de bereikte maxima en minima individueel verschilien.

Het röntgeneffect is goed $z i c h t b a a r$ te maken door de ratio $S / G_{2} M$ voox te stellen als functie van de tija (fig. 7.4.5.) 
Fig. 7.4 .4 .

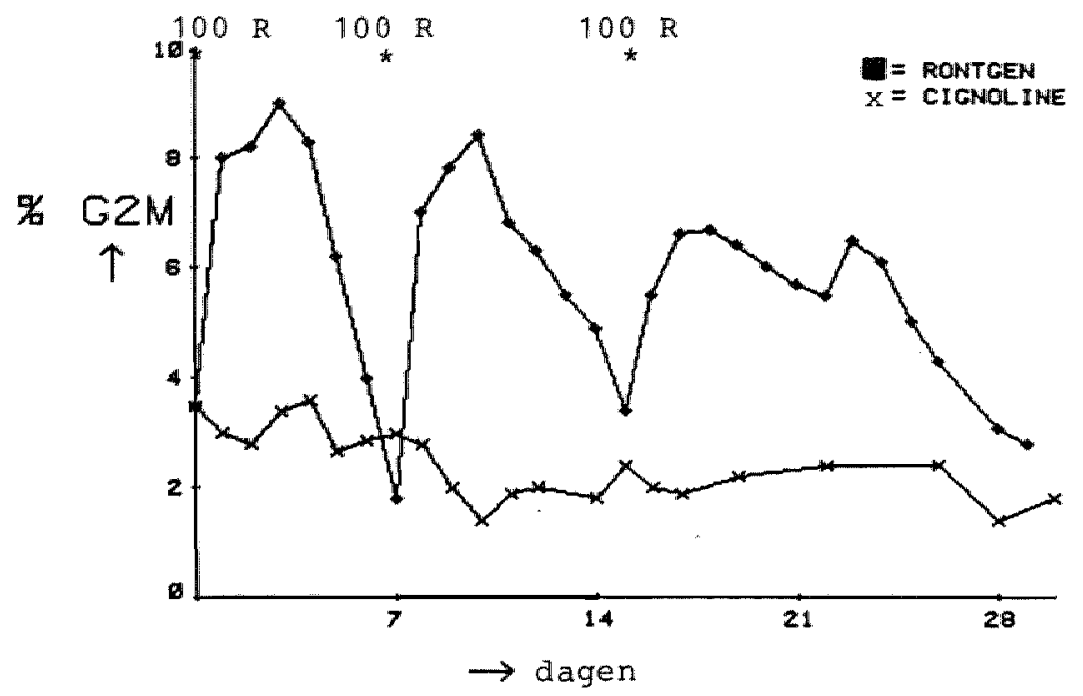

Fig. 7.4.4.: toont de percentages $\mathrm{G}_{2} \mathrm{M}$ in de DNA histogrammen van celsuspensles uit psoriasislaesies die met röntgenstralen resp. dithranol (cignoline) zijn behandeld.

Eig. $7.4 \cdot 5$.

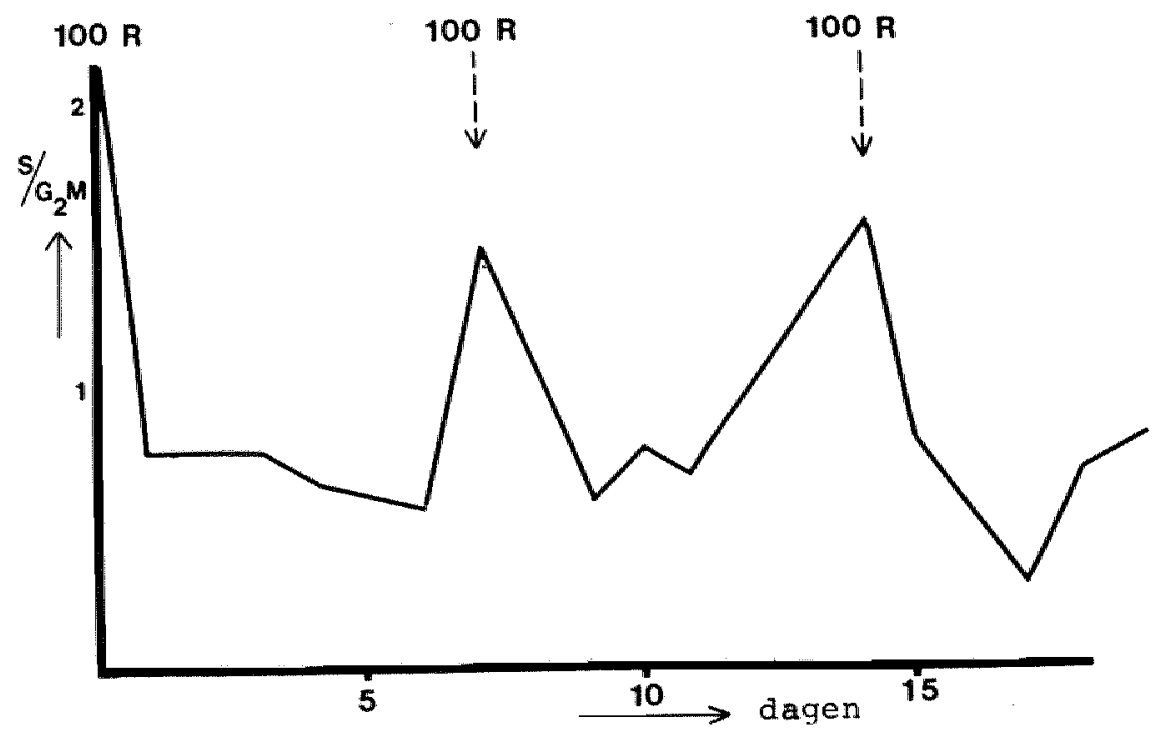

Fig. 7.4.5.: toont de ratio $S / G_{2} M$ als functie van de tijd na bestralingen met $100 \mathrm{R}(30 \mathrm{KV}, 0,30$ A1, FHA: $30 \mathrm{~cm}$ ). 
Voor het verkrijgen van inzicht in de eventuele effecten van rontgenbestraling op de celkinetiek van humane epidermiscellen zou het wenselijk geweest zijn de effecten van een érnmalige röntgenbestraling op normale huid te onderzoeken. Hiervan is echter om ethische redenen afgezien. De flowcytometrische methode is gevoelig genoeg gebleken om de veranderingen in DNA distributie in met rontgenstralen behandelde psoriasislaesies te registreren.

Een snelle stijging van het aantal cellen in de $G_{2}$ fase wordt binnen 24 uur gezien bij alle onderzochte patienten. Na 72-96 uur wordt een maximum bereikt waarna een daling optreedt. Daar deze stijging noch in de met dithranol behandelde laesie, noch in de normal uitziende huld optreedt, is het aannemelijk dat $z i j$ berust op rontgenbestraling. Dit is in overeenstemming met de stijging wan de $G_{2}$ M fractie gevonden na röntgenbestraling door Crissmann et al. (1975). ook interne straling door b.v. $\mathrm{H}^{3}$-thymidine geeft een sterke toename van het aantal cellen in de G2M fase, waarbij de grootte en de duur van de toename afhankelijk is van de hoeveelheid geincorporeerde radioactiviteit (Fingerhut et al., 1980 ; Baisch \& Böhmer, 1980).

Hoewel de $G_{2}$ cellen niet $\operatorname{van} M$ cellen kunnen worden onderscheiden met behulp van de flowcytometer, wordt aangenomen dat verreweg de meeste cellen in deze toegenomen $\mathrm{G}_{2} \mathrm{M}$ fractie $G_{2}$ cellen zijn, omdat bij microscopisch onderzoek geen sterke toename van het aantal mitosefiguren wordt gezien. De mogelijkheid dat late $s$ fase cellen een bijarage leveren aan de $G_{2} M$ piek kan niet worden geëlimineerd. Niet alle fasen van de celcyclus zijn even gevoelig voor röntgenstralen. Fidorra \& Linden vinden dat de overgang $S-G_{2}$ en de vroege $G_{2}$ fase het meest gevoelig voor röntgenstralen zijn. Het midden van de $G_{1}$ fase is in loun experimenten het minst gevoelig voor deze bestraling.

Behalve een stijging van het antal tetraploide cellen vertonen de DNA histogrammen van alle onderzochte patienten tevens een zeer snelle daling van het aantal cellen in de $S$ fase, gevolgd door een stijging na $48-72$ uur. In de ons bekende literatuur hebben we geen bevestiging van een dergelijke kortdurende verandering in de $s$ fractie kunnen vinden. In onze experimenten loopt de $s$ fractie kennelijk op korte termijn leeg. Volgens Baisch \& Bohmer (1980) zou interne straling geen effect hebben op de progresisie van de cellen door de $S$ fase. Het is mogelijk dat de cellen reversibel worden gehinderd de synthese van DNA te beginnen."Wanneer dit relatief kleine percentage cellen opgat in de $2 c$ piek komen deze cellen niet tot uiting in de DNA histogrammen. 
Baisch, H. \& Böhmer, R.M.: Effect of internal radiation of tritiated BUdR incorporated into DNA on the progression of cells through the cycle. Flowcytometry, 4:359-361, 1980 .

Baxter, D.I. \& Stoughton, R.B.: Mitotic index of psoriatic lesions treated with anthralin, glucocorticosterold and occlusion only. J. Invest. Derm., 54:410-412,1970.

Belsito, D.V. \& Kechijian, P.: The rolle of tar in Goeckerman therapy. Arch. Dermato1.,118:319-321,1982.

Bishop, S.C. \& Gray, B.C.: DNA repair activity in human skin after ultraviolet or PUVA exposure. In: Psoriasis, proceedings of the third international symposium. Ed. by Farber, E.M. \& Cox, A.J.: $443-444 ; 1981$.

Born, W.: Zur Wirkung von Cignolin auf die DNS-Synthese in der Epidermis. Hautarzt, 20:178-181, 1969.

Braun-Falco, O. \& Lukacs, S. : Dermatologische Röntgentherapie. Ein Leitfaden für die Praxis. Springer Verlag, Beriin, b1z. 136,1973 .

Braun-Falco, O. Burg, G. \& Schoefinius, H.H.: Ueber die Wirkung von Dithranol (Cignolin) bel Psoriasis vulgaris. Arch. Derm. Forsch., 241:217-236,1971.

Cole, R.S.: Light-induced cross-1inking of DNA in the presence of a furocoumarin (psoralen). Blochem. Biophys. Acta, $217: 30-39,1970$.

Comaish, S.: Ingram method for treating psoriasis. Arch. Dermatol., $92: 56-58,1965$.

Comaish, S., Smith, J. \& Seville, R.H.: Factors affecting the clearence of psoriasis with dithranol (anthralin). Br. J. Derm. $84: 282-293,1971$.

Cotton, D.W.K. \& Van Rossum, E. : Psoriatic therapeutics and glucose-6-phosphatase dehydrogenase. Arch. Derm. Forch.,252* $147-149,1975$.

Cox, A.J. \& Watson, W.: Histological variations in lesions of psoriasis. Arch. Dermato1.,106:503-506,1972.

Crissmann, H.A., Mullaney, P.F. \& Steinkamp, J.A.: Methods and applications of flow systems for analysis and sorting of mammalian cells. Methods Cel1. Biol.,9:179-246,1975.

Dall'Acqua, F., Marciani, S., Ciavatta, I. \& Rodighiero, G.: Formation of interstrand cross-11nkings in the photoreactions between furocoumarins and DNA. Z. Naturforsch.,26:561569,1971 . 
Dugois, R., Amblard, P., Martel, J., Morin, J. \& Reymond, J.L.: La therapeutique du psoriasis par l'association ultraviolets-anthralin. Journées Nationales de Dermatologie, Montpelller, 1975 .

Epstein, E.: Photosensitization in the treatment of psoriasis. J. Invest. Derm.,8:203-207,1947.

Epstein, J.H. \& Fukuyama, K.: Effects of 8-methoxypsoralenInduced phototoxic effects on mammalian epidermal macromolecule synthesis in vivo. Photochem. Photobiol.,21:325-330, 1975.

Epstein, J.H. Fukuyama, R. \& Fye, R.: Effects of ultraviolet radiation on the mitotic cycle and DNA, RNA and protein synthesis in mammalian epidermis in vivo. Photochem. Photobío1. 12:57-65,1970.

Fidorra, J. Linden, W.A.: Radiosensitivity and recovery of Mouse-L-cells during the cell cycle. Radiat. Viron. Blophys. 14:285-294,1977.

Eingerhut, R., Otto, F. Kiefer, J.: Cellular radiation effects and hyperthermia: The influence of genetically determined radiosensitivity on the cytokinetic behaviour of stationary yeast cells after $x$-radiation and hyperthermia. In: Elowcytometry, $4: 196-199,1980$.

Fischer, T.: UV-light treatment of psoriasis. Acta Derm. Venereol., $56: 473-479,1976$.

Fisher, L.B. \& Maibach, H.I.: In: Psoriasis, Proceedings of the International Symposium at Stanford University. Ed. by Farber, E.M. \& Cox, A.J., p. 335, Stanford University Press, stanfora, California, 1971.

Fisher, I.B. \& Maibach, H.I.: The effect of anthralin and its derivatives on epidermal cell. kinetics. J. Invest. Derm., $64: 338-341,1975$.

Frank, L., Steiner, K. \& Bender, B.: Flluandrenolone and occlusion in psoriasis. Arch. Dermatol.,89:404-410,1964.

Fry, L. \& McMinn, R.M.H.: The action of chemotherapeutic agents on psoriatic eptdermis. Br. J. Derm.,80:373-383, 1968 .

Galewsky, E.: Veber Cignolin, ein Ersatzpräparat des Chrysarobins. Derm. Wschr.,62:111-115.1916.

Goeckerman, W.H. : The treatment of psorlasis. Northwest Med., $25: 229-231,1925$.

Goldschmidt, H.: FDA Recommendations on radiation of benign diseases. Arch. Dermatol, ,114:1149,1978. 
Honigsmann, H. Jaenicke, $\mathbb{R} . F$, Brenner, W., Rauschmeier, W. \& Parrish, J.A.: Unscheduled DNA synthesis in normal human skin after single and combined doses of UV-A, UV-B and UV-A with methoxsalen (PUVA). Br. J. Derm.,105:491-501,1981.

Ingram, J.T.: The approach to psoriasis. Br. Med. J.,2:591594,1953 .

Ingram, J.T.: The significance and management of psoriasis. Br. Med. J., $2: 823-828,1954$.

Kammerau, B., Zesch, A. \& Schaefer, H.: Absolute concentrations of dithranol and triacetyl-dithramol in the skin

layers after local treatment. J. Invest. Derm. 64:145-149, 1975.

Kenicer, K.J.A., Lakshmipathi, T., Addo, H.A., Johnson, B. E. \& Erain-Bell, W.: An assessment of the effect of photochemotherapy (PUVA) and UV-B phototherapy in the treatment of psoriasis. Br. J. Derm. , 105:629-639,1981."

Klem, E.B.: Effects of antipsoriatic drugs and metabolic inhibitors on the growth of epidermal cells in culture. J. Invest. Derm.,70:27-31,1978.

Krebs, A. \& Schaltegger, H.: Experimentelle Untersuchungen aber den wirkungsmechanismus von Chrysarobin und bithranol bei Psoriasis (Indizen für eine cytostatische wirkung an der Epidermis). Dermatologica, 131:1-27,1969.

Kruger, J.P., Christophers, E. \& Schlaak, M. : Dose-effects of 8-methoxypsoralen and UV-A in cultured human lymphocytes. Br. J. Derm., $98: 141-144,1978$.

Lata, K. , Jain, V., Mishra, R. \& Bhutani, L.: In vitro effects of 2-deoxy-d-glucose after photochemotherapy of psoriasis. In: Psoriasis, proceedings of the third International Symposium. Ed. by Farber, E.M. \& Cox, A.J.:439-440,1981.

Lawler, L.C. \& Vineyard, W.R.: The effect of treatment on the vascular component of psoriasis lesion. Aroh. Dermatol.. $82: 190-193,1960$.

Lehmann, K.E.: Fluoreszensmikroskopische Untersuchungen zur Permeation von Anthralin (Cignolin, Bayer) in die mensichliche Haut. Med. Diss., Düsseldorf, 1965.

Lerche, A., Sondergaard, J., Wadskov, S., Leick, V. \& Bohr, V.: DNA interstrand crosslinks visualised by electron microscopy in PUVA treated psoriasis. Acta Dermatovener.,59:1520,1979 .

LeVine, M.J. \& Parrish, J.A.: outpatient phototherapy of psoriasis. Arch. Dermato1.,116:552-554,1980. 
LeVine, M.J., White, H.A.D. \& Parrish, J.A.: Components of the Goeckerman regimen. J. Invest. Derm.,73:170-173,1979.

Liden, S. Michalesson G.: Dithramol (anthralin) in psoriasis. Br. J. Derm. $91: 447-456,1974$.

Martinmaa, J., Juselius, J. Mustakallio, K.: Free radicals by auto-oxidation of anthralin and its 10-acyl analogues. Br. J. Derm., 105:52,1981.

Meiers, H.G., Kuhling, K. Ippen, H. : Untersuchungen über die enzymhemmende wirkung von 1, 8-dihydroxy-anthranol-9

(Clgnolin). Dermatologica, 136:497-503,1968.

Mier, P.D., Van Den Hurk, J., Bauer, F.W., De Grood, R.M. \& Roelfzema, H.: Mitotic activity and acid hydrolase levels In human epidermis following a single dose of ultraviolet radiation. Br. J. Derm.,96:163-165,1977.

Mortazawi, S.A.M. \& Oberste-Lehn, H.: Lichtsensibilisatoren und ihre therapeutischen Fähigkeiten. Z. Haut Geslechtskr., $48: 1-9,1973$.

Musajo, L., Bordin, F., Caparole, G., Marciani, S. \& Rigatti, G.: The mechanism of action of the skin photosensitizing furocoumarins. Acta Dermatovenereol. 47:298-303,1967.

Musajo, L. \& Rodlghiero, G.: Photophysiology, vol. VII, led. by A.C. Glese) pp. 115-147, Academic Press, New York, 1972 .

Mustakallio, K.: Irritation, staining and antipsoriatic activity of 10-acyl analogues of anthralin. Br. J. Derm. 105: $23-27,1981$.

Oppenheim, M.: Die Behandlung der Psoriasis vulgaris mit intravenösen Tryptaflavininjectionen und Quarzlicht. Strahlentherapie, $29: 268-274,1928$.

Parrish, J.A., Fitzpatrick, T.B., Tanenbaum, L. \& Pathak, M. A. : Photochemotherapy of psoriasis with oral methoxsalen and long wave ultraviolet light. N. Eng. J. Med.,291:12071211,1974 .

Pathak, M.A. \& Kramer, D.M.: Photosensitization of skin in vivo by furocoumarins (psoralens). Biochim. Biophys. Acta., $195: 197-206,1969$.

Pull Imann, H., Enderer, K. \& steigleder, G.K.: Cytokinetic effects of anthralin on psoriatic keratinocytes. Br. J. Derm. $105: 55-56.1981$.

Raab, W.: Die Wirkung externer Antipsoriatica auf die Gewebsatmung menslicher und tierischer Haut. Arch. klin. exp. Derm. ,234:44-51,1969. 
Rassner, G.: Aktivitätshemmung von Enzymen des Kohlenhydratstoffwechsels durch Dithranol. Arch. klin. exp. Derm.,24: $237-244,1971$.

Rodighiero, G.: Mechanism of skin photosensitization by furocoumarins: Photoreactivity of various furocoumarins with native DNA and with ribosomal RNA. Biochim. Blophys. Acta, $217: 40-49,1970$.

Röntgencommissie Nederlandse Vereniging van Dermatologen. Bestuurlijk schrijven, 1976.

Schaefer, H., Farber, E.M., Goldberg, L. \& Schalla, W. " Limited application period for dithranol in psoriasis. Br. J. Derm., $102: 571-573,1980$.

Schauder, S. \& Mahrle, G.: Kombinierte Einstundentheraple der Psoriasis mit Anthralin und uv-Licht. Hautarzt, 33:206209,1982 .

Segal, A., Katz, Ch. \& Duurer, B.L.: structure and tumour promoting activity of anthralin (1,8-dihydroxy-9-anthrone) and related compounds. J. Med. Chem.,14:1152-11154,1971.

Selim, M.M., Goldberg, I., Schaefer, H. , Bishop, S. \& Farber, E.M.: Penetration studies on topical anthralin. Br. J. Derm., $105: 101-103.1981$.

Steigleder, G.K. Raab, W.: Absorption of x-rays in psoriatic parakeratotic horny layers. J. Invest. Derm.,38:299304,1962 .

Steigleder, G.K., Schumann, H. \& Lennartz, K.J.: Autoradiografie in vitro-examination of psoriatic skin before during and after dithranol treatment. Arch. Derm. Forsch.,246:231235,1973 .

Swanbeck, G. \& Thyresson, N.: Interaction between dithranol and nucleic acids. Acta Dermatovener, $45: 344-348,1965$.

Swanbeck, G. Zetterberg, G.: Studies on dithranol and dithranol-11ke compounds. Acta Dermataverex:, 51:41-44, 1971.

Swanbeck, G., Thyresson, N. , Bredberg, A. \& Lambext, B.: Treatment of psoriasis with oral psoralens and longwave ultraviolet light. Acta Dermatovener.,55:367-376, 1975 .

Tuliplan, L.: Treatment of psorlasis with photosensitizing agents. Arch. Derm. Syph.,43:99-102,1941.

Unna, P.G.: Cigrulin als Heilmittel der Psorlasis. Derm. Wschr. $62: 116-137 ; 150-163 ; 175-183,1916$.

Walter, J.F., Stoughton, R.B., Dequoi, P.R.: Suppression of epidermal proliferation by ultraviolet light, coal tar and anthralin. Br. J. Derm., 99:89-96,1978. 
Weber, G.: Combined 8-methoxasalen and black light therapy of psoriasis. Br. J. Derm., 90:317-323,1974.

Weigand, D.A. \& Everett, M.A.: Clearing of resistant psortasis with anthralin. Arch. Dermatol., 96:554-559, 1967 .

Weinrich, E.G. \& Kettlewell, P.J.: Die Einfürung des Chrysarobins in Europa. Dermatologica, 144:115-127,1972.

Wolff, K., Hönigsmann, H., Gschait, F. \& Konrad, K.: Photochemotherapie bei Psoriasis. Klinische Erfahrungen bei 152 Patienten. Dtsch. med. Wschr., 100:2471-2477,1975.

Wolff, K., Henseler, T., Hönigsmann, H., Chxistophers, E. and 30 participating investigators: The European PUVA study: 3000 patients. In: Psoriasis, Proceedings of the third International symposium, Ed. by Farber, E.M. \& Cox, A.J.:427-428, 1981 .

Zetterberg, G. \& Swanbeck, G.: Studies on dithranol and dithranol like compounds II, Mutagenicity. Acta Dermatovener., $51: 45-49,1971$. 
In HOOFDSTUK 1 wordt een beknopt overzicht gegeven van het ziektebeeld psoriasis, warbij slechts op enkele aspecten van dit complexe phenomeen wordt ingegaan teneinde de niet met deze aandoening bekend zijde lezer enige kennis van deze huidafwijking te bieden.

In HOOFDSTUK 2 wordt een literatuuroverzicht wan in de loop der jaren toegepaste methoden ter bestudering van de celkinetiek gegeven, toegespitst op normale humane epidermis en psoriasis. De door diverse auteurs gevonden waarden voor celcylcustijden en turnovertijden van normale epidermis lopen sterk uiteen en zijn op onderdelen tegenstrijaig.

Bij psoriasis zijn alle auteurs het erover eens dat de proliferatieactiviteit is verhoogd, zij het met forse verschillen in toename. De meningen over de duur van de synthesefase van een prolifererende psoriasiscel zijn tegenstrijaig. Over een verkorting van de totale celcyclustijd bij psoriasis, zij het ook weer in wisselende mate, zijn alle auteurs het eens.

De flowcytometrische onderzoeken naar celkinetische aspecten van normale en pathologisch veranderde humane epidermis zijn beperkt in de literatuur maar bleden goede mogelijkheden tot statistisch meer betrouwbaar celkinetisch onderzoek.

In HOOFDSTUK 3 wordt de in dit onderzoek gebrulkte flowcytometrische methode uiteengezet. De flowcytometer, de afname techniek, de bewerking van het monster, de analyse van de gegevens en een aantal moeilijkheden bij de interpretatie worden achtereenwolgens beschreven.

In HOOFDSTUK 4 worden de DNA distributies in normale humane epidermis vermeld. De invloed van het geslacht, de leeftifd en de plaats op het lichaam is onderzocht. Tevens 1 s gekew ken naar verschillen in DNA verdeling tussen twee specifieke tijden van het jaar.

Uit de verkregen waarden is een schatting gemaakt van de turnovertijd van het levend epitheel $(18,5$ dagen) en de gemiddelde celcyclustijd (139 uur) van een normale keratinocyt.

In HOOFDSTUK 5 worden de DNA distributiles in psoriasis vulgaris, onrustige psoriasis en psorlasis pustulosa vermeld. De onderlinge verschilien in percentage celler in de $s$ en $G_{2} M$ fase zijn significant tussen deze drie vomen van psoriasis.

Vergeleken met normale epidermis is bij psoriasis de variatie in de individuele specimens groot. De intra- en inter- 
individuele variantle alsmede de intralaesionale variantie is onderzocht. De individuele subpopulaties blijken significant meer homogeen te $z 1 j n$ dan de totale populatie. Binnen eenzelfde laesie zijn er in de hier onderzochte parameters geen verschillen tussen rand en centrum van de laes.te.

In de kdinisch niet aangetaste epidermis bij personen met psoriasis is de DNA distributie significant verschillend van die in normale epidermis en in psoriasis. Het percentage $S$ en $G_{2} M$ heeft waarden tussen die van normale huid en van psoriasis in.

ook voor een psoxiasiscel is uit de verkregen waarden een schatting gemaakt van de celcyclustijd (67 uur) en de turnovertijd $(5,5$ dagen $)$.

In HOOFDSTUK 6 zijn de DNA distributies in klinisch niet aangetaste epidermis en in laesies van neurodermitis, lichen ruber planus en m. Darler onderzocht.

Blj lichen ruber planus en m. Darier is er geen verschil tussen laesle en normal uitziende huid; bij neurodermitis is het percentage cellen in de $s$ fase significant hoger in de laesie.

Normale epidermils verschilt in de hier onderzochte parameters niet van de normale epidermis bij deze drie huidaandoeningen.

Neurodermitislaesies verschillen significant voor de $S$ en $\mathrm{G}_{2} \mathrm{M}$ fractie wan de celcyclus van de overeenkomstige fracties van zowel normale epidermis bij controle personen als van psoriasislaesie.

Lichen ruber laesie verschilt niet van normale epidermis. Bij $\mathrm{m}$. Darler zijn de verschilien in de onderzochte parameters van de celcyclus net significant verschillend van die van normale epidermis.

Psorlasis verschilt in percentage $S$ van alle drie dermatosen.

In HOOFDSTUK 7 zijn met behulp van de flowoytometer de theraple-effecten van dithranol applicatie, Govekerman therapie, PUVA behandeling en röntgenbestraling op een psoriasislaesie bepaald.

Dithranol applicatie blijkt een asymmetrie van de rechter flank van de $2 \mathrm{c}$ piek te geven. Voor deze asymmetrie zijn meerdere oorzaken denkbaar. Het feit dat ook de $4 c$ piek een asymmetrische rechter flank vertoont doet ons ertoe neigen een voorkeur uit te spreken voor de hypothese dat onder invloed van dithranol applicatie een subpopulatie keratinocyten ontstaat die een afwijkende kleuringskarakteristiek heeft.

In de psoriasiscellen afkomstig uit laesies die een Goeckerman behandeling hebben ondergaan wordt slechts een minimale daling van het percentage $S$ en $G_{2} M$ gezien.

Een éenmalige PUVA behandeling van normale epidermis geeft een tijdelijke toename van de $4 \mathrm{c}$ piek. Ook in psoriasiscellen treedt na dagelijks PUVA bestralingen na een individueel bepaalde tijd, een sterke stijging van de $G_{2} M$ fractie op. 
In de klinisch niet aangetaste epidermis blijkt de grootte van deze toename afhankelijk te zijn van het aantal Joules/ $\mathrm{cm}^{2}$ opgestraald UVA licht. Het therapeutische effect van PUVA lijkt te bestaan uit eliminatie in de $\mathrm{G}_{2}$ fase van een aantal cellen uit de prolifererende populatie.

ook in de DNA histogrammen van celsuspensies van eenmalig met röntgenstralen behandelde psoriasislaesies treedt een sterke stijging van het percentage $G_{2} M$ op. Na enkele dagen daalt dit percentage weer tot de uitgangswaarde. Synchroon met de toename van het aantal $\mathrm{G}_{2} \mathrm{M}$ fase cellen ontstaat een sterke daling van het aantal DNA synthetiserende cellen. Het percentage $S$ bereikt een minimum wanneer $G_{2} M$ maximaal is en stijgt vervolgens weer. Een tweede bestraling geeft opnieuw deze effecten. Na enkele bestralingen stijgt het percentage $\mathrm{S}$ niet meer om uiteindelijk een niveau te bereiken van klinisch niet aangetaste epidermis bij psoriasis. Het tijdsinterval dat nodig is om de $G_{2} M$ fractie weer de uitgangswaarde te laten aannemen lijkt na elke bestraling toe te nemen. De tijdelijke toename van cellen in het $G_{2} M$ compartiment kan verklaard worden door aan te nemen dat een deel van de de celcyclus doorlopende celpopulatie irreversibel in de $G_{2}$ fase wordt geblokkeerd. De hieropvolgende daling wordt dan veroorzaakt door lysis of door migratie van de geblokkeerde cellen naar het huidoppervlak. 
In CHAPTER 1 a short review is presented of the symarome psoriasis. Only some aspects of this complex phenomenon are discussed.

In CHAPTER 2 a synopsis is given of the literature concerning the methods applied throughout the years, to study cell kinetics of normal human epidermis and psoriasis. Cell cycle times and turnover times of normal epidermis as calculated by different authors, differ significantly and some of the results are even contradictory. In case of psoriasis all authors agree on an 1 ncreased proliferation activity, although with rather divexging values. opinions on the duration of the $S$ phase of a proliferative psoriatic cell are contradictory. All authors agree however that the cell cycle time of psoriatic keratinocytes is shorter, though this 1 s difficult to establish quantitatively. The flow cytometric studies of cell kinetics of normal and pathologically changed human epidermis are rare in literature, but they offer good possibilities towards statistically more reliable cell kinetic research.

In CHAPTER 3 the flow cytometric method as used in this study is outlined. The flow cytometer, the sampling technique, the preparation of the sample, the analysis of the data and a number of difficulties in interpretation are successively described.

In CHAPTER 4 Elow cytometric measurements of the DNA content are performed on a large number of skin biopsies of normal human epidermis.

The influence of sex, age and body-site is examined. Moreover, differences in DNA aistribution between two specific times of the year have been looked into.

Crude estimations of turnover time of the viable epidermis $(18,5$ days) and of the mean cell cycle time (139 hours) of normal keratinocytes have been made.

In CHAPTER 5 the DNA distributions in psoriasis vulgaris, unstable psoriasis and psoriasis pustulosa are reported. The differences in percentages of cells in the $S$ and $G_{2} M$ phases are significant between these three types of psoriasis. Compared to normal skin the variation between the individual specimens is rather large. The intra- and interindividual variance as well as the intralesional variance have been examined. The individual subpopulations are signiflcantly more homogeneous than the total population. No slgnificance of possible differences between rim and centre of the lesion could be detected.

In uninvolved skin of patients with psoriasis the DNA distribution differs significantly from those of psoriasis lesion and normal skin.

The values obtained for the percentages of $S$ and $G_{2} M$ celis of unlinvolved skin are found in between those of normal 
skin and psoriasis.

The turnover time of psoriatic skin (5,5 days) and the cell cycle time (67 hours) of the psoriatic keratinocytes have been estimated.

In CHAPTER 6 the DNA distributions in lesions and in uninvolved skin of patients with neurodermatitis, lichen ruber planus and morbus Darier (dyskeratosis follicularis) are presented. Lichen ruber planus and $\mathrm{m}$. Darier show no difference between involved and uninvolved skin. In involved skin of neurodermatitis the percentage of $S$ phase cells is significant ly elevated.

The significance of possible differences between the involved and uninvolved skin of these three dermatoses and normal and psoriatic skin is successively discussed.

In CHAPTER 7 changes in DNA distribution in psoriatic skin during different types of therapy are investigated.

During dithramol therapy a temporal asymmetry of the right flank of the $2 \mathrm{c}$ peak was observed. Several explanations for this phenomenon are possible. We would like to believe that application of dithranol stimulates the devellopment of a subpopulation of psoriatic keratinocytes with abnormal colour characteristics.

Psoriatic cells treated with Goeckerman regimen show only minor changes in the percentages of cells in $S$ and $G_{2} M$. The effect of a single dose of PUVA on normal keratinocytes is a temporal increase of the percentage $4 \mathrm{c}$ cells.

In psoriatic cells an increase in the percentage of $G_{2} M$ was measured following daily PUVA treatments. However there were differences in individual response.

In uninvolved skin the rate of increase depends on the dose of UVA light.

The therapeutic effect of PUVA seems to consist of a removal in the $\mathrm{G}_{2}$ phase of a part of the proliferative cells from the population.

After a single dose of $x$-rays we observe an increase in the percentage $G_{2} M$, reaching a maximum value after $3-4$ days.

Thereafter the percentage $G_{2} M$ steadily drops. Synchronously a sharp decrease in the percentage $S$ is abserved, the lowest point of which colncides with the highest point of $G_{2} M$. Thereafter the percentage s increases towards its original value. A second radiation dose produces simular effects, although the maxima and minima are less marked. After several radiation doses the percentage $S$ shows no increase anymore and will reach a level comparable to that of uninvolved psoriatic skin and it takes a longer time for the $G_{2} M$ to become normal again. The temporal increase of cells in $G_{2} M$ after $x-r a y$ radiation can be explaned by assuming that a fraction of the cycling cells is being irreversibly blocked in the $G_{2}$ phase of the cell cycle and that the gradual removal of the blocked celis from the population is taken place by $1 y-$ sis or migration to the skin surface. 
De auteur dankt allen die direct of indirect hebben bijgedragen aan de tot stand koming van dit proefschrift.

In het bijzonder wil ik bedanken Prof. Dr. W.J.B.M. van de Staak en Dr. F.W. Bauer. Zonder de steun van de eerste en het geduld van de laatste zou dit proefschrift het levenslicht niet hebben aanschouwd.

Gaarne wil ik noemen Prof. Dr. J.W.H. Mali die mij tijdens mijn opleiding tot dermatoloog in de gelegenheid heeft gesteld het wetenschappelijk werk te verrichten dat tot dit proefschrift heeft geleid.

Ing. G.J. de Jongh en Ir. J.B.M. Boezeman dank 1 k voor hun vele arbeid betreffende de statistische bewerking van de verkregen meetresultaten.

ook ben ik dank verschuldigd voor de consistente medewerking die ik heb mogen ondervinden van Mevr. R.M. MaassenDe Grood bij het laboratoriumwerk en van Mevr. W. VerbeeckSilla die de basisversies van dit proefschrift heeft getypt. Zeker wil ik niet vergeten Marion Teunissen voor het vele werk besteed aan het uittypen van de uiteindelijke tekst. Tenslotte een zeer speciaal woord van dank aan mijn vrouw Rini die mij met raad en daad terzijde heeft gestaan en aan mijn dochters Laurence en Anne-Claire die steeds voor de nodige afleiding hebben gezorgd. Zeer in het bijzonder ben ik ook dank verschuldigd aan de vele patienten die door hun grote bereidwilligheid de vaak vele benodigde huidmonsters beschikbaar te stellen een conditio sine qua non vormden voor de realisatie van dit proefschrift. 
De auteur van dit proefschrift werd geboren op 26 december 1948 te Bunde.

In 1967 behaalde hij het einddiploma gymnasium beta aan het Henric van Veldeke college te Maastricht.

Daarna studeerde hij geneeskunde aan de Rijksuniversiteit Leiden, waar op 2 april 1972 cum laude het doctoraalexamen en op 21 juni 1974 het artsexamen werd behaald.

Na een korte periode als warnemend huisarts was hij tot augustus 1975 werkzaam als dienstplichtig militair arts, terwijl in deze periode tevens een assistentschap interne geneeskunde (T.M.J. Ottenhoff, Breda) werd vervuld. In augustus 1975 starte hij met de opleiding tot dermatoloog in de Universiteitskliniek voor Huidziekten te Nijmegen (hoofd: prof. Dr. J.W.H. Malil. Registratie als dermatoloog vond plaats op 11 augustus 1979 .

Sedertdien wordt de dermatologische praktijk uitgeoefend in associatief verband met A.J.M. Penders en volgde a anstelling als staflid in het Canisius-Wilhelmina Ziekenhuis te Nijmegen (Directeur-Geneesheer: W.Th.F. Filippini). 